\title{
Advances in Designing and Developing Vaccines, Drugs and Therapeutic Approaches to Counter Human Papilloma Virus
}

\begin{abstract}
Maryam Dadar ${ }^{1 *}$, Sandip Chakraborty ${ }^{2}$, Kuldeep Dhama ${ }^{3 *}$, Minakshi Prasad ${ }^{4}$, Rekha Khandia ${ }^{5}$, Sameer Hassan ${ }^{6}$, Ashok Munjal ${ }^{5}$, Ruchi Tiwari ${ }^{7}$, Kumaragurubaran Karthik ${ }^{8}$, Deepak Kumar ${ }^{9}$, Hafiz M. N. Iqbal ${ }^{10}$ and Wanpen Chaicumpa ${ }^{11}$

${ }^{1}$ Razi Vaccine and Serum Research Institute, Agricultural Research, Education and Extension Organization, Karaj, Iran, ${ }^{2}$ Department of Veterinary Microbiology, College of Veterinary Sciences and Animal Husbandry, West Tripura, India, ${ }^{3}$ Division of Pathology, ICAR-Indian Veterinary Research Institute, Bareilly, India, ${ }^{4}$ Department of Animal Biotechnology, LLR University of Veterinary and Animal Sciences, Hisar, India, ${ }^{5}$ Department of Genetics, Barkatullah University, Bhopal, India, ${ }^{6}$ Department of Biomedical Informatics, National Institute for Research in Tuberculosis, Indian Council of Medical Research, Chennai, India, ${ }^{7}$ Department of Veterinary Microbiology and Immunology, College of Veterinary Sciences, U P Pt. Deen Dayal Upadhayay Pashu Chikitsa Vigyan Vishwavidyalay Evum Go-Anusandhan Sansthan, Mathura, India, ${ }^{8}$ Central University Laboratory, Tamil Nadu Veterinary and Animal Sciences University, Chennai, India, ${ }^{9}$ Division of Veterinary Biotechnology, ICAR-Indian Veterinary Research Institute, Bareilly, India, ${ }^{10}$ Tecnologico de Monterrey, School of Engineering and Sciences, Monterrey, Mexico, ${ }^{11}$ Department of Parasitology, Center of Research Excellence on Therapeutic Proteins and Antibody Engineering, Faculty of Medicine Slriraj Hospital, Mahidol University, Bangkok, Thailand
\end{abstract}

Human papillomavirus (HPV) is a viral infection with skin-to-skin based transmission mode. HPV annually caused over 500,000 cancer cases including cervical, anogenital and oropharyngeal cancer among others. HPV vaccination has become a public-health concern, worldwide, to prevent the cases of HPV infections including precancerous lesions, cervical cancers, and genital warts especially in adolescent female and male population by launching national programs with international alliances. Currently, available prophylactic and therapeutic vaccines are expensive to be used in developing countries for vaccination programs. The recent progress in immunotherapy, biotechnology, recombinant DNA technology and molecular biology along with alternative and complementary medicinal systems have paved novel ways and valuable opportunities to design and develop effective prophylactic and therapeutic vaccines, drugs and treatment approach to counter HPV effectively. Exploration and more researches on such advances could result in the gradual reduction in the incidences of HPV cases across the world. The present review presents a current global scenario and futuristic prospects of the advanced prophylactic and therapeutic approaches against HPV along with recent patents coverage of the progress and advances in drugs, vaccines and therapeutic regimens to effectively combat HPV infections and its cancerous conditions.

Keywords: human papilloma virus (HPV), prophylaxis, vaccines, drugs, therapy 


\section{INTRODUCTION}

Human papilloma virus (HPV) infection is usually a commonly encountered infection (transient) which has attracted the attention of media in recent years due to the advancement in the field of vaccine development and changes in recommendations for screening of cancer $(1,2)$. HPV is found to be the causative agent for dermatologic diseases and sexually transmitted diseases (3). Across the globe, HPV vaccination has become a public health priority, with many national programs with international alliances launched in several countries of the world. This vaccine can help prevent cases of HPV infection that may result in precancerous lesions, cervical cancers, and genital warts, especially in adolescent females and males. Universal HPV vaccination worldwide will result in a gradual reduction in the incidence of HPV cases (4). The Papillomaviridae family comprises more than $130 \mathrm{HPV}$ genotypes that have been isolated from various human neoplasias such as warts, cancers, and cases of recurrent respiratory papillomatosis (RRP) (5). The prevalence and distribution of HPV types differ by geographic region. Moreover, HPV types in 30,848 invasive cervical cancers worldwide revealed differences by geographical region and histological type (6). This virus is a significant cause of mortality and morbidity in the developing countries (7). Globally, cervical cancer ranks as the second most common cancer in women and is responsible for a significant number of deaths (453 million). High-risk HPV, consisting of more than 100 types of HPV, is an important cause of cervical cancer $(8,9)$. Through the process of immunization along with other therapies, it is possible to control the HPV-associated cancers and such opportunity is created through the process of identifying HPV as a causative agent for malignancies. Against infectious diseases as a tradition use of vaccines have been done as a preventive measure. Success has been achieved in developing prophylactic vaccines against HPV types that cause disease by making the viral L1 (major capsid protein) as target $(10,11)$. It is, however, to be kept in mind that there is not enough evidence for demonstrating the efficacy of the prophylactic vaccines for treatment of HPV infections and lesions associated with HPV $(12,13)$.

To control HPV infection, HPV vaccines have been introduced into national immunization programs (14). Since 2013, HPV vaccines (bivalent and quadrivalent) have been included in the national immunization programs of at least 66 nations, including NorthAmerica and Western Europe, primarily (15). Recombinant HPV virus-like particles (VLPs) are being produced at commercial level via heterologous expression of the major capsid protein L1 in yeast or insect cells (16). From the morphology viewpoint, VLPs are similar to natural HPV virions with considerable potentialities to induce animal and human type-specific antibody responses (17). A patent has been granted to (18) for developing a technique of disassembly and reassembly of VLPs to enhance the stability of VLPs. The present HPV vaccines are capable of preventing persistent HPV infections, as well as protecting against premalignant cervical lesions (19). Once HPV infection was established as the main cause of cervical and other types of cancer, our focus turned to typing of HPV by field testing with new diagnostics and applying effective HPV immunization strategies for cancer control (20). Licensed VLP-HPV vaccines should provide long-term safety and effective protection against targeted HPV types. Also, to determine the optimal ages for effective vaccination, their design should address the effects of vaccine modulators, mode of delivery, expandable coverage of HPV types, and effects on males and targeted pre-adolescents or adults (21). HPV vaccines are recommended for both adolescent males and females, and after these vaccines were introduced, a marked reduction in the prevalence of HPV-associated cancers has been observed (22). It is to be noted that no serious adverse events in relation to vaccine has been reported (23, 24).

Among effective prophylactic HPV vaccines, Cervarix (a bivalent vaccine) is protective against adenocarcinoma-causing types including HPV-16, 18, 31, 33 and 45 for a documented period of 6.4 years. Whereas, Gardasil (a quadrivalent vaccine) has been confirmed to protect against genital warts, respiratory papillomatosis, and certain types that cause squamous cell cancer, including HPV-6, 11, 16, 18, and 31, for 5 years (10). Despite these successes, vaccination against HPV has triggered much debate. Also, use of these vaccines in developing countries is essentially non-existent, mainly because of its high cost and the difficulty of introducing them into vaccination programs, as they both require three injections over a 6-month period for girls (25). Gardasil and Cervarix are effective vaccines against HPV, generally, but their coverage of HPV types is limited, and their use in pregnant women is not advised; hence, vaccines with a broader preventative and therapeutic spectrum and better safety profile are desired.

Chimeric vaccines, multivalent vaccines to address HPV types (broader spectrum) or to combine HPV with other pathogens, edible vaccines, biodegradable and mucoadhesive polymer-based vaccines, and various viral vectors harboring recombinant HPV DNA vaccines are being developed for greater immunogenicity than that of current vaccines. Similarly, for a more recipient-friendly vaccine, needleless immunization technologies, including the use of a jet gun, gene gun, and microneedles are being evaluated for HPV cancer prevention (26). Lyophilized HPV pseudovirions have been delivered to murine models using microneedles (27). Studies exploring PubMed, EMBASE, Cochrane Library, and clinicaltrials.gov databases for published reports on immunogenicity and safety of bivalent and quadrivalent vaccines, specifically in Asian populations, have suggested strategies for developing vaccines that elicit enhanced HPV-16- and HPV-18- specific antibody levels (28). In light of the serious consequences of HPV-associated cancers and warts, HPV vaccination should be included in the standard childhood vaccination regimen (29).

The present review presents a current global scenario and futuristic prospects of the advanced prophylactic and therapeutic approaches against HPV along with recent patents coverage of the progress and advances in drugs, vaccines and therapeutic regimens to effectively combat HPV infections and its inducedpathological sequels. 


\section{HPV DISEASE}

HPVs belong to a large family of non-enveloped, small, approximately $7.9-8 \mathrm{kbp}$ circular dsDNA viruses that are surrounded by an icosahedral protein capsid composed primarily of a highly immunogenic L1 protein, with a minor contribution from the $\mathrm{L} 2$ protein $(30,31)$. The virus is the cause of squamous epithelial cell proliferation, or common warts, on areas of the body such as the hands, feet, anus, cervix, scrotum, groin, thigh, or penis (32). The life cycle of the virus is divided into five phases. Infection and subsequent uncoating is the first phase wherein there is an affection of the basal cells. Genomic maintenance is the second phase during which there is an expression of the early proteins of the virus, viz., E1 and E2. This is followed by the proliferative phase wherein there is an expression of some other early proteins like E6 and E7. The cell cycle progresses after being stimulated by such proteins. Subsequently, there is a synthesis of the virus which is the fourth phase during which there is an expression of the late viral proteins, viz., L1 and L2. The virus is packaged in the epithelial layer under the influence of these late/structural proteins. During shedding of the dead cells at the stratified epithelial layer, there is the release of the virus (fifth phase) which can then cause infection of other cells $(33,34)$.

HPVs with different oncogenic potential have been assigned to three main groups: high-risk types, intermediate-risk types, and low-risk types. High-risk types include HPV-16, 18, 31, 33, 35, $39,45,51,52,56,58,59,68,73$, and 82 ; intermediate-risk types include HPV-26, 53, and 66; and low risk-types include HPV-6, $11,40,42,43,44,54,61,70,72$, and 81 . Among these types, $70 \%$ of cervical cancers result from type 16 and 18 infections, and if multiple HPV types infect women, persistent HPV infections can be established, and cervical cancer exacerbated $(26,35)$. There is also the involvement of HPV- 33 and 45 in causing squamous cell carcinoma and adenocarcinoma, respectively (36). It is to be mentioned in this regard that the low-risk HPV viruses and the oncogenic types are responsible for causing warts (anogenital) and cervical dysplasia, respectively (34).

HPV is held responsible for the trends in the increase in the rate of oropharyngeal carcinoma as is revealed by molecular detection methods. The viral nucleic acid is detectable in a clinical specimen by polymerase chain reaction at a much greater frequency after the year 2000 as compared to before 1990 in the United States alone. The involvement of HPV in oropharyngeal carcinoma has greatly increased during a span of 20 years in the Netherlands from 1990 to 2010. Similar is the situation in another European country like Spain $(37,38)$.

Despite this, most HPV infections induce no or only mild cytological abnormalities; and few HPV infections lead to cervical cancer. HPV can also cause cervical and other cancers such as cancer of the vulva, vagina, penis, or anus. It can also cause cancer in the back of the throat, including the base of the tongue and tonsils (39). Usually HPV infections clear within 1-2 years' time, but if multiple HPV types infect a person, the viruses may persist, leading to lethal cancers in various parts of the body. In one study by the U.S. Centers for Disease Control (CDC) conducted from 2004 to 2008, an average of 33,369 HPV-associated cancers was diagnosed annually. Therefore, CDC projected that every year roughly 26,000 new cancer cases occurred as a result of HPV infection, including 18,000 cases in females and 8,000 in males. In the U.S., cervical cancer prevention is based on two approaches: one primary and one secondary. The primary strategy is regular HPV immunizations, and the second strategy is screening of populations at risk or immunized to reduce HPV-related cancers (40).

Among oncogenic HPVs, genotypes 6 and 11 cause laryngeal papillomas and most of the genital warts, whereas types 16 and 18 are responsible for $70 \%$ of cervical cancers. To prevent infection with highly transmissible HPV, a quadrivalent (types $6,11,16$, and 18) HPV vaccine has been evaluated and shown good results in clinical trials. Similarly, a bivalent vaccine (types 16 and 18) has shown greater than 90\% protection against persistent HPV infections, even 5 years post-vaccination. In both, the vaccines were non-infectious, DNA-free VLPs, developed using recombinant technology, administered in conjunction with appropriate adjuvants, and three doses at 6-month intervals have been shown to elicit high-titer serum antibodies (41).

A study performed in young women 15-25 years of age to assess the immunogenicity and efficacy of a human papillomavirus 16 and 18 (HPV-16/18) AS04-adjuvanted vaccine against cervical intraepithelial neoplasia (CIN) grade 1 or greater (CIN1+, CIN2+, or CIN3+) showed that vaccination of adolescent girls before their first sexual encounter resulted in better protection and prevention of HPV-associated cervical cancers and persistent infections (42). The HPV-16/18AS04-adjuvanted vaccine reduced the incidence of high-risk human papilloma viruses in a randomized cluster trial in adolescent girls and boys, irrespective of their lifestyles and sexual behavioral patterns (43).

The clinical efficacy of bivalent (HPV-16 and 18), quadrivalent (HPV- 6, 11, 16, and 18), and nonavalent (9vHPV; HPV$6,11,16,18,31,33,45,52$, and 58) vaccines against cervical cancer was tested. The bivalent and quadrivalent vaccines reduction in the rate of HPV-16 and 18 prevalences significantly compared to that of the 9vHPV vaccine and all three vaccines decreased the morbidity and mortality from cervical cancers resulting from oncogenic HPVs (44). The HPV-16/18-AS04-adjuvanted vaccine, when administered in a one-dose schedule to adolescent girls 9-14 years of age and evaluated for immunogenicity and safety, showed clinically acceptable results compared to a three-dose vaccine schedule for women aged 15-25 years (45). Another clinical trial (controlled phase II/III) that evaluated an HPV-16/18-AS04-adjuvanted vaccine in women showed that the vaccine efficiently reduced HPV-16/18 infection, provided cross-protection against some non-vaccine-type oncogenic HPVs that cause genital warts, and protected against oral, vulvar, and anal HPV infection regardless of the age, geographical location, or sexual practice of study participants (46). One 7-year follow-up study on phase III, double-blind, randomized controlled trial from 2006 to 2014 evaluated the efficacy, safety, and immunogenicity of the HPV-16/18-AS04-adjuvanted vaccine in women older than 
25 years (in groups ranging 26-35 years, 36-45 years, and $\geq 46$ years). Control women received aluminum hydroxide, whereas vaccinated women were immunized with the HPV$16 / 18$ vaccine. Results showed that the HPV-16/18 vaccine was effective in all age groups and protected against HPV-associated lesions $(\mathrm{CIN} 1+)$, and corresponding cytological abnormalities, irrespective of the infecting HPV type. Hence, this vaccine was shown to be reliably effective against HPV infections (47). Studies have shown that immunizations with the HPV16/18-AS04-adjuvanted vaccine do not promote autoimmune disease (48).

Chronic local inflammation, alone or as a result of oral HPV infection, may play an important role in the etiology of head and neck squamous cell carcinomas (49). A study conducted in over 624 nursing students in Izmir, Turkey, revealed that the students had a very high level of knowledge as far as the risk factors and the transmission modes of the disease are concerned but such knowledge has not been used practically to make the vaccination against HPV successful (50). A mathematical modelbased analysis has been utilized for systematic screening in women in the U.S. to protect the health benefits and harms; costs involved in vaccination with the bivalent, quadrivalent or nonavalent vaccine (51). Increased awareness of the health risks of HPV infection, such as cervical cancer and warts that results from education and self-testing is an important component in screening and diagnosing initial infections and advanced cases of HPV-associated cancers (52).

\section{Advances in Developing Prophylactic And Therapeutic Vaccines Against HPV}

Because the cultivation and propagation of HPV in cell/tissue culture are difficult, developing inactivated or live attenuated HPV vaccines is not a common practice. Therapeutic vaccines against HPV can be categorized into nanoparticle-, bacterial-, live vector- (bacterial and viral), nucleic acid- (DNA and RNA), protein-, peptide-, cell- (cytokine-transduced autologous tumor cells and dendritic cells [DCs]) based vaccines [reviewed in (53) and (54)]. Cytotoxic T lymphocyte (CTL) responses elicited by therapeutic vaccines against HPV early viral gene products E1, E2, E5, E6, and E7 (53). Therapeutic vaccines targeting E6 and E7 (early proteins encoded by HPV) are most common because these proteins are produced in all HPVinfected cells and are vital for cancer cells $(53,55)$. Therefore, researchers have focused on developing unconventional newgeneration prophylactic and therapeutic HPV vaccines targeting capsid proteins or the genome by genetic engineering and recombinant DNA technology. The prophylactic vaccines are relatively safer (56-58). It is interesting to note that there is enhancement of cell mediated immunity by $\mathrm{T}$ cell based vaccines in contrast to prophylactic vaccines (that help in generating neutralizing antibodies) (59). At present, the questions that arise regarding vaccination against $\mathrm{HPV}$ is the protection period (specially, in relation to cross protection). Moreover the shortcomings of the VLP vaccines, viz., less thermal stability, lack of efficacy therapeutically, cost, etc., are also required to be overcome (60).
Various new approaches are presented as below:

\section{Protein-Based Subunit Vaccines}

These include subunit or subvirion products that induce protective immunity. Fusion protein PD-E7 vaccines comprise a mutated HPV-16 E7 protein linked to the first 108 amino acids of Haemophilus influenzae protein D (PD), adjuvanted with AS02B. Vaccinated patients with oncogenic HPV-positive CINs mount significant E7- and PD-specific IgG responses (61). The therapeutic SGN-00101 vaccine (also known as HspE7, developed by StressGen), based on the fusion of the E7 protein of HPV16 and recombinant heat shock protein 65 (Hsp65) of Mycobacterium bovis, was evaluated for protection against anal neoplasia (62). Vaccination with SGN-00101 at a dose of $500 \mu \mathrm{g}$ administered at 3-week intervals induced immune responses and lesion regression in women with high-grade CINs (63).

\section{SGN-00101}

as a potential treatment for cervical tumors (64) and RRP (65) was evaluated. SGN-00101 induces the activity of CTLs in women having cervical intraepithelial lesions (CIN) (66). An HPV-6 L2/E7 fusion protein is another protein-based vaccine that induces antibodies against HPV-16 oncoproteins. ProCervix (GTL001) is adjuvanted with Aldara developed by Genticel; it consists of HPV-16 E7/HPV-18 E7 bivalent adenylate cyclase (CyaA)-based vaccine that targets HPV-16 and 18 infections (67). ProCervix has been proposed to clear HPV-16 infection while protecting against later infection with HPV-18. A phase 1 clinical trial for safety and immunogenicity of the ProCervix vaccine revealed that HPV clearance was several-fold higher in the group treated with ProCervix than in the placebo group (68).

\section{Peptide-Based Vaccines}

As far as such type of vaccine is concerned, characterization of various specific epitopes has been done for the human MHC class I (HLA-A2) peptides. In mammalian models, the cell-mediated immune response is generated by immunizing with a peptide that carries E6 or E7 origin epitopes (69). Various peptide-based vaccines include extended epitope-specific peptides, synthetic long peptides (SLPs), or lipopeptides. SLPs consisting of peptides from HPV-16 (nine E6 and four E7) (HPV-16-SLP adjuvanted with Montanide ISA-51) were tested in phase II clinical trial (70) and interestingly in case of humans multiple clinical trials have been conducted for studying the HPV-16-SLP (long peptide vaccine) (70-72). Examples of this kind of vaccine include those constructed with HPV-16 E7 12-20, E7 86-93, E7 8693, E7 11-20, and E7 86-93 lipopeptides (54, 73, 74), HPV-16 E7 86-93 (CIGB-228 vaccine) adjuvanted with very small-sized proteoliposomes (VSSPs) (73), as well as HPV-16 E7 49-57 with a poly-IC (a Toll-like receptor [TLR]3 agonist) and anti-CD40 monoclonal antibody as the TriVax vaccine (75).

\section{Epitope-Based Vaccines}

Vaccines designed using a traditional approach involve attenuation of a pathogen by sub-culturing, which is a long and tedious process that can take up to 15 years, and the safety of these vaccines is a matter of concern $(76,77)$. Bioinformatics is 
an important multidisciplinary tool that may allow optimization of the health benefits of vaccines.

In silico tools, paired with improvements in recombinant DNA (rDNA) technology and knowledge of the host immune response and genetic background of the pathogen, will contribute to the future development of new vaccines (78). The first step toward applying bioinformatics to vaccine development consists of identifying epitopes that are potentially immunoprotective from those that are not (76). Prediction of T and B cell epitopes has been the main focus of immunoinformatics, and over the years many different tools have been developed (79). With the advent of bioinformatics and high-throughput technologies, vaccine research has entered a new era, and vaccine design has benefitted from the development of vaccine databases and in silico vaccine design tools (80).

A prediction for the 16 major epitope variants (V1-V16) in the full-length L1 protein of HPV-16 and evaluation of the immunogenicity of these variants and reference DNA vaccine constructs was recently reported by Kumar et al. (81). The results of this study showed that the L500F (V16) and T379P (V8) variants induced a $\sim 2.7$-fold $(p<0.002)$ increase and $\sim 0.4$ fold $(p<0.328)$ decrease in antibody titer, respectively, after the final injection. This study offered a roadmap for the use of both in silico tools and experimental methods to develop DNA-based vaccines. The authors also suggested that multi-epitope DNA vaccines might induce more effective immune response against HPVs with different epitope variants than those constructed without a consideration of this variation (81).

In another study, in silico tools (B-cell and T-cell epitope prediction methods) were used to design a subunit vaccine against HPV (82). Using a conserved sequence in the L1 binding protein gene from 20 different sequences, the authors proposed a possible HPV vaccine target. Based on their analysis, the authors reported that the $\mathrm{L}_{41}$ protein of HPV was a promising candidate for vaccine design.

Yao et al. (83) identified E6 and E7 proteins as ideal candidates for therapeutic vaccines against HPV-16 infection. A total of 81 CTL epitopes in HPV-16 E6 $(n=59)$ and E7 $(n=22)$ were predicted using Immune Epitope Database Analysis Resource. Among the 20 clusters of epitopes in HPV-16 E6 generated, cluster 3 contained the most epitopes (10 epitopes), representing HLA-A*31:01 and $-A^{*}$ 33:03. Of the 10 clusters of HPV-16 E7, cluster 3 contained the most epitopes (5 epitopes), representing HLA-A*01:01 and $-A^{*} 26: 01$. Based on their observations, the authors suggested that a cocktail of E6 and E7 epitopes such as 52FAFRDLCIVYR62 of E6 (HLA-A*02:06, HLA-A*31:01, and HLA-A*33:03), 66PYAVCDKCLKF76 of E6 (HLA-A*11:01 and HLA-A*24:02), 2HGDTPTLHEY11 of E7 (HLA-A*01:01 and HLA-A*26:01), and 11YMLDLQPETT20 of E7 (HLA-A*02:01) could be used to vaccinate more than $50 \%$ of all individuals worldwide (83).

de Oliveira et al. (84) reported the designing of a multi-epitope recombinant protein. It contains the immunogenic epitopes of E6 and E7 proteins. This particular recombinant protein can protect against $\mathrm{HPV}$-induced tumors in $\mathrm{CD} 4^{+} \mathrm{T}$ cell-deficient mice but not in mice deficient in $\mathrm{CD}^{+} \mathrm{T}$ cells. Moreover, the activities of the T cells that are E6/E7 specific are also enhanced. So the use of this multi-epitope protein is assumed to be a promising approach to design a potent vaccine therapeutically against HPV-induced tumors.

In another study, biopsies of nine cervical cancers (HPV-16-infected) in patients with HLA-A*02 were obtained. The E7 oncogene-coding region was reported to be conserved in all tumors. Of the nine samples, the $\mathrm{E}_{11-19}$ peptide (11YMLDLQPET19) was detected by MS3 analysis of the HLA-A ${ }^{*} 02$ immunoprecipitate from seven of them. However, of the 13 epitopes predicted using the in silico approach, only one was observed through an exquisitely sensitive physical detection method, suggesting that bioinformatic prediction should be used to identify probable epitopes for confirmation by physical detection. Because the conserved E7 ${ }_{11-19}$ peptide is the dominant HLA-A*02 binding tumor antigen in HPV-16 transformed cervical squamous cells cancers and adenocarcinomas, it has the potential to be used for the development of therapeutic cancer vaccines (85).

Sequence alignment studies have detected that the L2 proteins of HPV are having greater intertype variability than L1 which is responsible for the lower consistency of L2 protein as far as positioning in the variable region is concerned. There is the presence of greater number of epitopes in the region of L1 that is conserved and such regions are the prime targets for antibodies (neutralizing types). It can, therefore, be mentioned without a doubt that as far as designing vaccine is concerned a better target is L1 protein compared to L2 (86). In silico approaches to predict the epitopes are highly valuable compared to conventional procedures that are costly and time-consuming. The predicted peptides can then be tested both in vitro and in vivo to verify their effectiveness in triggering an immune response. Assays with short peptides (overlapping) covering the entire sequence of the targeted protein/antigen are used to define CTL epitopes (MHC Class I restricted). Determination of the epitopes of HPV-16 is also done in the same way (53).

\section{Recombinant Vaccines}

\section{Recombinant adeno-associated virus ( $r A A V$ )}

Intranasal immunization against HPV-16 with recombinant adeno-associated virus (rAAV) type 5 encoding the major capsid protein L1 of HPV-16 showed that a single-dose of this vaccine without an adjuvant was sufficient to elicit high titers of mucosal antibodies in vaginal washes and L1-specific serum antibodies (87). Immunization of mice with a single dose of AAV5-HPV-16 L1 intranasally results in the development of both cell-mediated as well as humoral immunity for a prolonged period (88). Another study showed that rAAV-type 9 administered intranasally to mice induced high-titer and longlasting neutralizing antibodies against HPV-16 (89). A mutated HPV-16 E6/E7 gene, whose product is not oncogenic, was cloned into an adenoviral vector, and the vector elicited an immune response that increased the clearance of established HPV-positive-cancer in vivo (90).

\section{Recombinant measles virus (MV) vaccine}

A vaccine expressing the L1 capsid protein of HPV-16 that was designed to protect against HPV-16 infection revealed measles virus for to be a valuable vehicle for the development 
of inexpensive and effective vaccines $(91,92)$. In another study, Gupta et al. (93) administered a recombinant liveattenuated MV Edmonston-Zagreb (rMVEZ) strain as a viral vector carrying heterologous genes that encoded the L1 major capsid proteins of HPV-16 and HPV-18 to rhesus monkeys (93). HPV-16L1/18L1-specific total IgG antibodies, neutralizing antibodies, and related cellular immune responses in non-human primates were comparable to those in response to the classical recombinant Pichia pastoris expressing HPV protein. A patent has been granted to Mendiretta et al. (94) for developing a dual vaccine applicable for treating measles and HPV by using measles vector and inserted genes coding for HPV antigens.

\section{Vaccinia virus Ankara (MVA)-based vaccines}

The growth of human tumors was effectively controlled by immunization with the recombinant vaccinia virus Ankara (MVA) expressing HPV E2 (MVA-E2). This vaccine showed potential to be used as a therapeutic vaccine (95). The viral vector-based MVA-E2 therapeutic vaccine inhibited HPV growth in high-grade lesions (CIN2 and CIN3) (96). Direct injection of the vaccine has been done in the uterine cervix (97). Immunization with this vaccine can eliminate precancerous lesions (CIN1, CIN2, and CIN3) associated with infection by oncogenic HPV types (98). A phase I/II study of the therapeutic MVA-E2 vaccine indicated that this vaccine is highly effective in inducing immune responses against human papilloma viruses and regression of flat condyloma lesions in men (99). The therapeutic antigen (TA)-HPV vaccine (improved by Celtic Pharmaca, previously Xenova or Cantab) is based on a live recombinant vaccinia virus strain (Wyeth) expressing a modified E6/E7 fusion protein of HPV-16 and HPV-18 (100). Safety and immunogenicity of the vaccine were confirmed in a proportion of those patients vaccinated (101). Injection of TA-HPV vaccine into the deltoid muscle has been done in a clinical study to patients having grade III vulvar intraepithelial neoplasia (VIN) and grade II vaginal intraepithelial neoplasia. After vaccination, identification of the enhancement of T-cell-based immunity (HPV E6 as well as E7 specific) has been done by employing interferon-gamma (IFN $\gamma$ ) ELISPOT assay (102). A booster vaccine TA-CIN (HPV-16 L2/E6/E7) in combination with TAHPV resulted in shrinkage of vulval intraepithelial neoplasias and symptom relief in some patients, with some showing an immune response (103). Multiple clinical trials have been conducted for evaluation of the efficacy as well as safety of MVA-based vaccine targeting the protein E2 $(55,104)$. For treating ano-genital lesions (intra-epithelial, including urethral condyloma or anal lesions) induced by HPV, phase III clinical study has been carried out (105). The sequences of attenuated MVA (recombinant) that encodes E6/E7 of HPV-16 (modified) are included in TG4001 vaccine. Further it is to be mentioned that this vaccine is nothing but MVATG8042 suspension (106).

\section{Bacteria-Based Vaccines}

The reporting of Listeria-based vaccine for therapeutic purpose against HPV was done for the first time in the year 2009 (107). Two different vectors of a live-attenuated Listeria monocytogenes (Lm) were engineered by Gunn et al. (108). In one, the Lm vector was secreted with E7 as Lm-E7, and, in the other, E7 was fused to non-hemolytic listeriolysin O (LLO) protein of the bacteria (Lm-LLO-E7) (Figure 1). The most important vaccine with anti-cancer activities is ADXS 11-001 (or ADXSHPV, formerly known as Lovaxin-C), a therapeutic Listeria-based vaccine targeting an HPV E7 antigen $(108,109)$ and resulting a TNF-alpha (TNF- $\alpha$ ) response and IL-2 production by DCs (110). The phase II FAWCETT trial (NCT02399813) is assessing the safety of ADXS11-001 in patients with metastatic squamous cell carcinomas of the anal canal (SCCA) and will be testing for protection against cervical, oropharyngeal, and anal cancers (111). Another bacteria-based vaccine expressing the viral E7 protein has been designed utilizing Lactobacillus casei as a vector. The safety of the $L$. casei-based vaccine is relatively high and oral administration is found to be fruitful. For evaluation of the cellular immunity, this particular vaccine has been administered in patients having CIN3. Majority of the patients that have received the vaccine responded well with regression of the disease which is associated with E7 specific cellular immunity. Enzymelinked immunospot (ELISPOT) assay has been employed for evaluation of the E7 specific-cellular immunity. When treatment with four-six capsules/day is done, there is exhibition of HPV E7 specific-cellular immunity in lymphocytes of the cervix (112, 113).

\section{Yeast-Based Vaccine}

A recombinant HPV-16 L1-expressing Schizosaccharomyces pombe yeast strain (HPV-16L1 yeast) produced edible HPV vaccines that were administered to female BALB/c mice (114). A codon-optimized HPV-16 L1 gene cloned into a non-integrative expression vector was transformed in Pichia pastoris yeast cells. Heparin-Sepharose chromatography was employed to purify L1 protein from the yeast extract. The resulting protein contained native conformational epitopes, as evidenced by immunoelectron microscopy, and showed great potential for use as a low-cost vaccine $(115,116)$.

\section{VLP-Based Vaccines}

There has been the adoption of VLPs as platforms for developing various candidates of HPV second-generation vaccine. VLPs have close resemblance with HPV particles (native) and include conformational epitopes which help in induction of neutralizing antibodies (26). Vaccines based on VLPs are safer to use while offering a display of B-cell epitope at greater density and presentation of T-cell epitopes intracellularly (117). So VLPs are known to be highly immunogenic. Due to the lack of viral gene, the VLPs are fully non-infectious as well as non-oncogenic in nature forming structure resembling the HPV virus outer shell. They induce production of antibodies that react with the virus $(26,118,119)$. Moreover, one interesting feature of VLP vaccine is that each of the vaccine has its adjuvant promoting durable immunity (120). But producing them on a large scale is expensive and difficult (54). Zhou et al. (121) explored VLP technology for the development of an HPV vaccine, which led to the most significant development in HPV vaccines and cervical cancer control (121). They expressed recombinant open reading frame (ORF) proteins L1 and L2 of HPV-16 in cells infected with a 


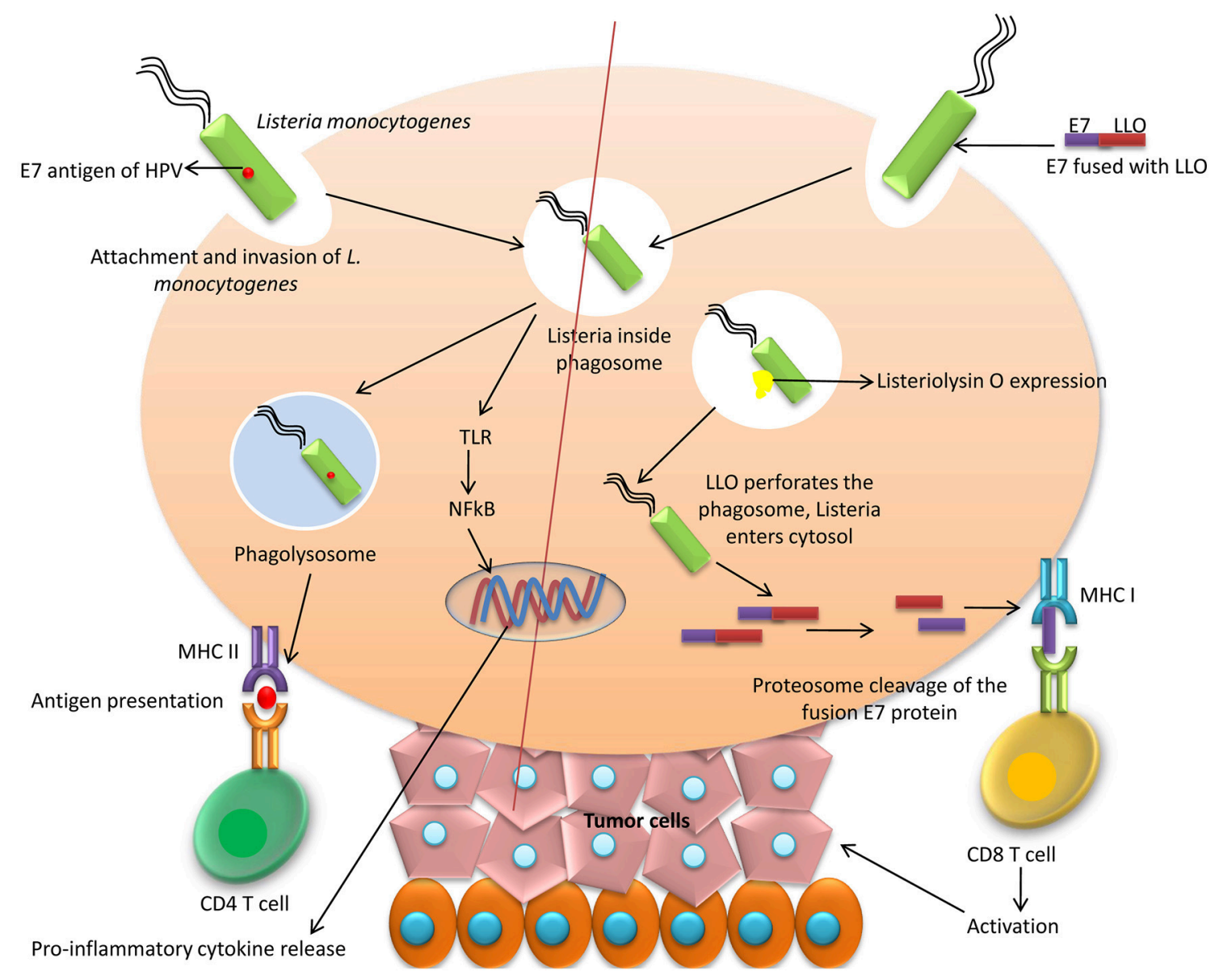

FIGURE 1 | Bacteria-based vaccines. Listeria monocytogenes can be used to secrete HPV E7 which activates CD4 helper T cells through MHC II antigen presentation mechanism. Another method of E7 delivery is to fuse E7 to non-hemolytic listeriolysin O (LLO) protein of the bacteria (Lm-LLO-E7) and thereby on delivery causes perforation of phagolysosome due to LLO and E7 protein made available to MHC I which activates cytotoxic T cells.

recombinant form of Vaccinia virus and explored the production of HPV-like particles, which is useful for biochemical studies and can provide a safe source of material for the development of vaccines. One promising alternative approach to producing recombinant VLP antigens is adding subdominant neutralizing epitope in the L2 protein of the HPV (122). In a 5-year study to assess the prophylactic efficacy of a quadrivalent HPV 6/11/16/18 L1 VLP vaccine in 552 adolescent and young adult females of 1623 years of age, vaccination reduced the incidence of cervical and genital cancers, precancerous dysplasias, and genital warts, and prevented infections with HPV-6, 11, 16, and 18 (123). When immunologic responses in 1106 young females against HPV types $6,11,16$, and $18 \mathrm{~L} 1 \mathrm{VLP}$ vaccine were measured, 12 - to 26 times higher levels of anti-HPV vaccine-type antibodies and an anamnestic protective immune response was observed, with no adverse side effects (124).

Mutant of Salmonella enterica serovar Typhi, i.e., Ty21a engineered to produce VLPs with HPV-16 L1 was administered as a potent live HPV vaccine to simultaneously induce protective immunity against cervical cancer and typhoid fever (125). Live bacteria-based HPV vaccines such as attenuated Shigella can be used to produce VLP (126) and to promote potent local and systemic immune responses (127). This is a prophylactic, efficient, and low-cost mucosal vaccine. Heterologous production of HPV-16 L1 protein in Lactococcus lactis was demonstrated using two vectors, pCYT, and pSEC, designed for intra- or extracellular expression, respectively (128). The results of a study by Cortes-Perez et al. (128) revealed that the use of recombinant food-grade lactic acid bacteria such as the L. lactis for the production of L1-based VLPs in a safe mucosal vector is a promising approach to creating HPV-16 prophylactic vaccines.

Abdoli et al. (129) designed HPV-16 VLPs with L1 protein in Spodoptera frugiperda 9 (Sf9) insect cells and suggested administration of recombinant baculovirus containing the HPV$16 \mathrm{~L} 1$ gene as a prophylactic vaccine and for diagnostic tests (129). Also, a modified baculovirus-based (MultiBac) approach to producing VLPs for heterologous expression of the HPV L1 protein in insect cells was used by Senger et al. (130). Self-assembly of the L1 protein of HPV-6a into VLPs was demonstrated in both $\mathrm{L} 1$ - and $\mathrm{L} 1+\mathrm{L} 2$ - coexpressing 
Saccharomyces cerevisiae (131). An alternative HPV antigen to elicit an immune response against HPV is the L1 pentameric subunit or capsomere with conserved neutralizing epitopes (132). Expression of recombinant HPV capsomeres in Escherichia coli may substantially reduce manufacturing costs. Studies in animal models have shown that HPV capsomeres alone induce lower antibody titers than those in VLPs (132). Expression of the L1 gene of HPV types 6 and 11;16 and 18 have been reported in S. cerevisiae for producing the HPV4 vaccine that is used for protection against persistent infection caused by HPV (133, 134). Another vaccine similar to HPV4 is HPV2, which is used for prevention of oncogenic HPV (23). In another study, a recombinant major capsid L1 protein of HPV-11 was produced intracellularly at high levels in an expression system based on galactose-inducible S. cerevisiae with an HPV-6/11 hybrid gene (135).

Moreover, VLPs of HPV-58 with the L1 protein produced in S. cerevisiae elicited antibodies and antigen-specific CD4+ and CD8+ T cell responses without the need for an adjuvant (136). Also, HPV-16 and -18 L1 protein expressed in E. coli to produce bivalent VLPs has been demonstrated safe and highly immunogenic as a vaccine candidate in preclinical studies (137). Fusion of HPV L1 to the surface of Shigella sonnei autotransporter, i.e., IcsA, introduced a new VLP strategy to improve live attenuated Shigella-HPV vaccines for better stability and more effective expression (138). Multivalent VLP vaccines for HPV were introduced by $\mathrm{Xu}$ et al. (139) and revealed that HPV-31 L1/L2 VLP-based vaccines induced strong typespecific and cross-reactive antibodies. Moreover, tobacco plantbased L1/L2 chimeras containing hybrid epitope sequences of HPV-16 L1/L2 induced anti-L1 and anti-L2 responses, and the antisera neutralized homologous HPV-16 and heterologous HPV-52 pseudovirions in mice (140). Vaccines targeting the L2 minor capsid antigen revealed particularly strong and longlasting antibody responses in mice, with a Th2 to Th1 shift in response (141). VLPs displaying HPV L2 peptides for capsid display, adjuvant ability, and fusion with early HPV antigens or TLR agonists are in development to improve upon licensed HPV vaccines (142). These vaccines elicit neutralizing antibodies and can block infection with a wide range of HPV types (143).

Recently, the capacity of AS04-adjuvanted vaccines based on VLP chimeras of L1 and two L2 epitopes to protect against HPV was evaluated, and these chimeric vaccines induced immunity and protected against various types of HPV (HPV-6, 11, 16, $31,35,39,45,58$, and 59 as pseudovirions or quasivirions) in both mouse and rabbit challenge models (144). Also, the use of different antigens such as oncogenic peptides, synthetic peptides, DNA, and bacterial antigens may allow the development of effective prophylactic and therapeutic vaccines that can address all of the issues associated with current vaccines.

Purified L1 capsomeres expressed in E. coli represent an economical alternative to (VLP)-based prophylactic vaccines against HPV-16 and 18 (145). Schädlich and colleagues reported that the L1 $\Delta \mathrm{N} 10$ protein was particularly immunologic and that L1 constructs could be administered to produce potent immunogenic responses to capsomeres in bacteria as a potentially inexpensive alternative to VLP-based formulations.
Furthermore, in another study, tobacco plants were used to express pentameric capsomeres of a modified HPV-16 L1 (L1$2 \mathrm{xCysM}$ ) protein to induce immunity against HPV (146). Licensing of subunit vaccine (VLP-based) from the L1 protein (plus adjuvant) has been done already (147). A novel VLP with HPV-16 E5 based on a whole gene as well as long multi-epitope gene version of E5 was designed by Cordeiro and collaborators (148). It is interesting to note that for judgment of subunit vaccines in future, the benchmark should be the HPV VLP vaccines (149).

\section{DNA Vaccines}

The safety of DNA (naked) is relatively higher. They are stable and lucrative due to ease of production and they have got application in sustaining expression of antigen in the cells at greater level (150-152). Additionally the DNA vaccines do not evoke anti-DNA antibodies for which their repeated administration can be done (153). Moreover, DNA vaccines offer several other benefits such as having inherent adjuvant properties that are lacking in a traditional peptide or attenuated-virus vaccines, and they are highly effective in treating HPV infections. In this category, ZYC-101 (developed at Eisai, formerly MGI Pharma and previously known as Zycos Inc.), the precursor of amolimogene bepiplasmid, which was evaluated in phase I clinical trial, is based on a bacterial plasmid (BIOTOPE). It encodes 25-residues of a human MHC class I antigen (HLA-DR $\alpha$ ) trafficking peptide (MAISGVPVLGFFIIAVLMSAQESWA) fused to an immunogenic peptide derived from the E7 protein of HPV-16 (82LLMGTLGIVCPIC94) (154). This vaccine is effective against anal and cervical dysplasias, with clinical outcomes consisting of regression of AINs (3/12 PRs), as well as regression of CINs (5/15 CRs) (155). Also, lesions showed the greatest regression in patients $<25$ years of age. In another study, DNA vaccine candidates with HPV-16 E6, E7, and L1 genes from an Iranian isolate inserted into the mammalian expression vector, pcDNA3 elicited therapeutic CTL responses to HPV-16 E6 and E7 proteins (156). In another study, a DNA vaccine expressing the E7 protein of HPV-16 with a mutation in the L-Y-C-Y-E pRbbinding motif at amino acids $23-25$ induced a potent CD8+ T cell immune response, as well as promoted significant anti-tumor effects in mice (157).

Moreover, the E7 oncoprotein of HPV linked to an interferoninducing $17-\mathrm{kDa}$ protein (ISG15) as an adjuvant elicited IFN- $\gamma$ responses and cytolytic effector CD8 T-cell responses (158). Recently, women with HPV-16 or 18 infections and normal cervical cytology showed potent immune responses to a GTL001 DNA vaccine with acceptable safety (159). Furthermore, Hsp70 can play a significant role in modified HPV-16 E7 and Mycobacterium tuberculosis $\mathrm{Hsp70}$ fusion DNA vaccine and introduce as candidate therapeutic tumor vaccine (160). Another vectored DNA-based vaccine is VGX-3100 (IgE leaderE6/E7 DNA) developed by Inovio Pharmaceuticals, which is administered intramuscularly by electroporation and targets the E6 and E7 proteins of HPV-16 and 18 in CINs 2/3 (161). VGX3100 is the first therapeutic vaccine to show efficacy against CIN2/3 associated with HPV-16 and 18. Safety, immunogenicity, and efficacy of this vaccine were evaluated in phase I clinical trial 
that recruited 18 women who were previously treated for cervical lesions. The intramuscular route (into the deltoid muscle) was adopted for administration of the vaccine. This was followed by electroporation $(162,163)$. Finally, these genotype-specific vaccines are in phase I clinical trials and in demand to resolve HPV infections and neoplasias (54).

However, it must be kept in mind that due to shortage of specificity (cell type) DNA vaccines show low immunogenicity. The DNA further lacks the capability (intrinsic) of amplification or nature of spreading to the cells (in vivo) in the surrounding. Nevertheless, there may be enhancement of potency of DNA vaccines (used against cervical cancer induced by HPV) by making DNA or the encoded antigen as the target to antigen presenting cells (APCs) and along with this, modification of the feature of APCs (antigen expressing) can boost immune response induced by the vaccine (153). Furthermore, it is also interesting to note that on employing as immunotherapeutic interventions (stand alone), the DNA-based anticancer vaccines are ineffective which can be explained by the establishment of immunosuppression (either systemic or local) (161, 164-167).

\section{Plant-Based Vaccines}

Production of candidate HPV vaccines in plant systems is a promising approach. These vaccines have been shown to be efficient and immunogenic, even though they are in the early stages of development $(168,169)$. One such vaccine is produced in microalgae that have immunomodulatory properties (170, 171). In one study, a plant codon-optimized version of the HPV11 L1 major capsid protein coding sequence was synthesized and transformed into tobacco and potato plants, resulting in immunologically functional VLPs. The ingestion of this material activated anti-VLP immune responses in mice (172). Moreover, the L1 major capsid protein gene of HPV-16, with or without nuclear localization signals, was integrated into the Nicotiana tabacum cv. Xanthi genome and the proteins were assembled into capsomeres to produce VLPs. Rabbits immunized with small doses of the transgenic plants showed weak anti-HPV-16 L1 immune responses (173). Also, HPV-11 L1 major capsid protein in transgenic Arabidopsis thaliana ecotype Columbia and $N$. tabacum cv. Xanthi was evaluated as candidates for a low-cost subunit vaccine. Results indicated that immunization of New Zealand white rabbits with $\sim 50 \mu \mathrm{g}$ of plant-derived HPV-11 L1 induced a weak immune response to native HPV-11 L1 VLPs, as well as to HPV-11 pseudovirions (174).

Expression of an HPV-16 L2 epitope fused to the $\mathrm{N}$ - and C-terminus of the coat protein of potato virus X (PVX CP) in transgenic $N$. benthamiana plants was evaluated by Cerovska et al. (175) and reported immunogenic in mice. In mouse sera, antibodies titers against PVX CP and the L2 epitope (108120) were measured after vaccine delivery (175). Another study revealed that the HPV-16 L1 protein expressed in tobacco chloroplasts induced the self-assembly of VLPs that were highly immunogenic in mice after intraperitoneal injection (176). A circular dsDNA replicon was constructed by cloning a secreted embryonic alkaline phosphatase (SEAP) reporter gene and promoter into a geminivirus-derived plant expression vector that was co-transfected with vectors expressing L1 and L2 proteins into $N$. benthamiana plants, and an HPV-16 pseudovirus was purified. This pseudovirus was neutralized by antisera against current and candidate HPV vaccines and represents a potential plant-derived vaccine (177). A $N$. benthamiana-derived fusion protein with beta-1,3-1,4-glucanase (LicKM) of Clostridium thermocellum elicited a protective response with a yield of 100 $\mathrm{mg} / \mathrm{kg}$ biomass with $99 \%$ purity after metal ion chelation and gel filtration purification (178). Transplastomic plants have been used for expression of mutated L1 gene of HPV. This results in the sole production of capsomeres that are pentameric in nature $(179,180)$.

\section{DC-Based Vaccines}

This promising approach has been used to produce HPV therapeutic vaccines. For example, HPV-16 E6 18-26 or HPV16 E7 12-20 peptides pulsed on immature DCs showed specific immune effects in women that were protective against advanced cervical cancer (181). In another study, a recombinant adenovirus encoding codon-optimized HPV-16 E6 and E7 proteins linked to DCs induced protective immunity against challenge by TC-1 cancer cells in vivo (182). For increasing the efficacy of DC-based vaccines not only antigens, but also novel strategies can also be incorporated into DCs. One classical example is the introduction of the small hairpin (sh) RNAsuppressor of cytokine signaling (SOCS1) into HPV-specific DC vaccine (E7 pulsed) (183). For evaluation of the immunogenicity as well as safety of such vaccines (DC-based), conduction of a dose escalation trial (phase I) has been done in cervical cancer (stage IIa or Ib) patients (184) In case of recurrency of cervical cancer also, phase I clinical trial has been conducted (185).

An overview of advanced vaccine technologies available for prevention and control of HPV is depicted in Figure 2.

\section{Currently Available Prophylactic Vaccines}

Currently, there are several licensed prophylactic HPV vaccines, including Cervarix, Gardasil, and Gardasil 9. These vaccines are all based on L1 structural proteins and are designed to inhibit HPV infections on first exposure. Gardasil and Cervarix both contain aluminum-based adjuvants and trigger strong protective immune responses. These two vaccines are beneficial in case of recurrent cervical cancer. Both Gardasil and Cervarix have a similar efficiency against HPV-16 as well as HPV-18 (186188). They are also safe to used (189). However, case reports from the U.S. Vaccine Adverse Event Reporting System (VAERS) have shown that in spite of their efficacy and safety, a few autoimmune side effects have occurred. These vaccines do not induce sufficient cross-protection against non-vaccine types of $\mathrm{HPV}$, as cross-protective immunity was shown to decline with the time $(190,191)$. To date, only bivalent and quadrivalent vaccines have shown efficacy; but a newer nonavalent vaccine is also under trial to evaluate its anti-HPV potential (192).

\section{Gardasil}

A tetravalent vaccine targeting HPV known as Gardasil or Silgard (qHPV-6/11/16/18 vaccine; Kenilworth, NJ, USA) was licensed in 2006 and is composed of $120 \mu \mathrm{g}$ of antigen per dose (VLP of 


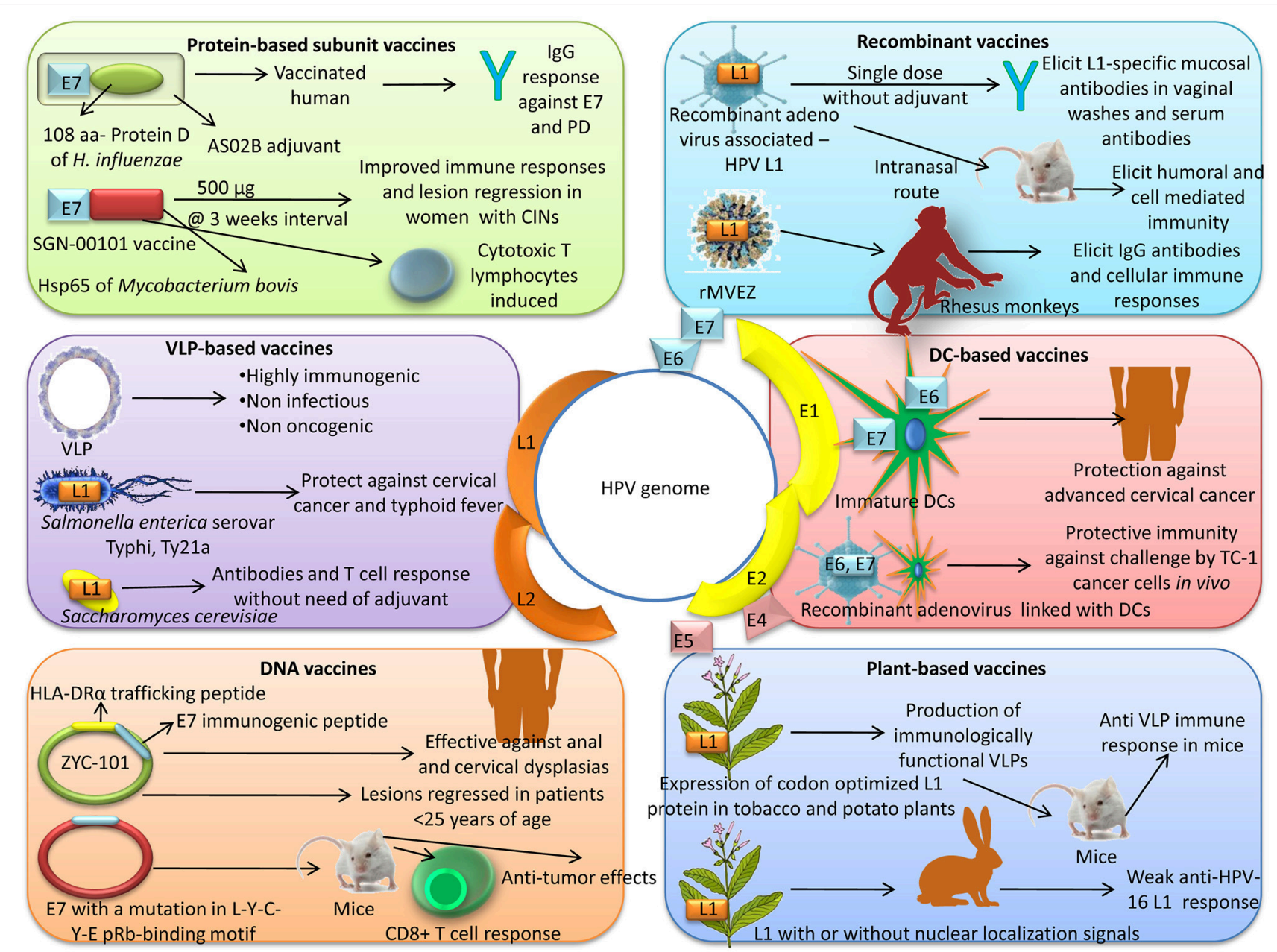

FIGURE 2 | Advanced vaccine technologies available for prevention and control of HPV.

recombinant L1 HPV-6 [20 $\mu \mathrm{g}$ ], VLP of recombinant L1 HPV$11[40 \mu \mathrm{g}$ ], VLP of recombinant L1 HPV-16 [40 $\mu \mathrm{g}$ ], and VLP of recombinant L1 HPV-18 [20 $\mu \mathrm{g}]$ ), adjuvanted with $225 \mu \mathrm{g}$ of aluminum hydroxyphosphate sulfate $(123,124,193)$. This vaccine is licensed in many countries and has been shown to be immunogenic and safe and to inhibit infections with other HPV serotypes. Elevated HPV antibodies have been found in all vaccinated persons, ranging from 9 to 45 years of age. Gardasil is administered in $0.5 \mathrm{~mL}$ per dose to girls and women ages 9 to 26 years for the control of cervical, vulvar, vaginal, and anal cancers induced by HPV-16 and 18, genital warts (condyloma acuminata) induced by HPV-6 and 11, and dysplastic lesions induced by HPV-6, 11, 16, and 18, as well as grades 1, 2 and 3 CINs, cervical adenocarcinomas in situ (AISs), grades 2 and 3 vulvar intraepithelial neoplasias (VINs), grades 2 and 3 vaginal intraepithelial neoplasia (VaINs), and grades 1, 2, and 3 anal intraepithelial neoplasia (AINs). Gardasil is also administered to boys and men 9 to 26 years of age for the control of anal cancers induced by HPV-16 and 18, genital warts (condyloma acuminata) induced by HPV-6 and 11, dysplastic lesions induced by HPV-6, 11,16 , and 18 , and grades 1,2 , and 3 AINs.
According to a FUTURE I and FUTURE II analysis, the efficacy of cervical and vulvar neoplasias and grade I VINs are 30,75 , and $48 \%$ respectively, and $83 \%$ for condyloma acuminate (194). Currently, the duration of protection by Gardasil is considered 9 years (195).

\section{Cervarix}

A bivalent HPV vaccine (HPV-2; Cervarix, GlaxoSmithKline Biologicals, Rixensart, Belgium) was licensed by the U.S. Food and Drug Administration (FDA) for administration to females 10-25 years of age (196) and has been approved in Europe and Australia (197). This is an L1 VLP vaccine that is produced in a cabbage looper moth cell line (Trichoplusia ni [Hi 5]) infected with recombinant baculovirus HPV-16 and $18 \mathrm{~L} 1$ and adjuvanted with $500 \mu \mathrm{g}$ of AS04, which consists of $50 \mu \mathrm{g}$ of 3-Odeacetylated-4-monophosphoryl lipid A adsorbed into $500 \mu \mathrm{g}$ of aluminum hydroxide (198). It consists of VLPs of HPV-16 and 18 , which induce $70 \%$ of cervical cancers worldwide and play important roles in HPV-related vulvar, vaginal, penile, anal, and oropharyngeal cancers $(199,200)$. The vaccine is composed of 20 $\mu \mathrm{g}$ of recombinant L1 from HPV-16 and $20 \mu \mathrm{g}$ of recombinant 
L1 from HPV-18 and is administered intramuscularly in three doses (the second dose given at least 1 month after the initial dose and the third dose given at least 6 months after the initial dose). The AS04 adjuvant in the vaccine induced increased expression of phenotypic maturation markers along with production of proinflammatory cytokines as well as cytotoxicity against tumor cells that are positive for HPV when interleukin (IL)-15 dendritic cell (DC) are exposed to the vaccine (201). The vaccine exerted immunity againsy HPV via a novel mode, i.e., boosted innate immunity, including killing of HPV-infected cells by DC and NK cells. The PATRICIA clinical study revealed the efficacy of the vaccine against HPV-16 and 18-associated precancerous cervical lesions to be $92.9-98.1$ and $30.4 \%$, respectively, and suggested cross-protection of other oncogenic HPV types such as HPV31 and $45(11,197)$. The effectiveness of this vaccine against CIN2+ lesions with HPV-16 and 18 has also been reported. The vaccine is well tolerated, highly immunogenic, and capable of generating high titers of neutralizing antibody to HPV-16 and 18 (202, 203). A phase III double-blind, randomized controlled trial of the Cervarix vaccine showed an efficacy of $90.4 \%$ against CIN2+ lesions with HPV-16 and 18 (203). Cervarix induces high antibody titers in comparison to natural infection. In women, there has been demonstration of an enhanced humoral immune response (204). Currently, the duration of protection generated by Cervarix is estimated to be 9.4 years $(205,206)$. One study showed that HPV universal mass vaccination of people in the UK with Cervarix prevented females from developing cervical cancer and protected males from HPV-16 and 18 infections (207).

\section{Gardasil 9}

Gardasil 9 (Merck and Co., Inc.), a 9vHPV $(6 / 11 / 16 / 18 / 31 / 33 / 45 / 52 / 58) \quad$ VLP-based vaccine provides protection against five additional oncogenic types (HPV-31, 33, 45,52 , and 58) and was approved by the FDA on December 10,2014 , for administration to females aged 9-26 years and males aged 9-15 years (208). Gardasil 9 targets up to $90 \%$ of genital warts (both Gardasil vaccines also target two HPV types responsible for $\sim 90 \%$ of genital warts) (209). A phase III clinical trial in women aged 16-26 years demonstrated the efficacy of the vaccine in inhibiting HPV infection (210). In another study, the safety and efficacy of the 9vHPV vaccine in males and females of 9-26 years were assessed across seven phase III clinical trials. The results showed that this vaccine was well tolerated in subjects with a serious and non-serious adverse event profile similar to that of the Gardasil qHPV vaccine, although injectionsite adverse events including pain, swelling, and erythema in both males and females and headache in felames were more common $(\geq 10 \%)$ with the 9vHPV vaccine (211). Increased use of the Gardasil 9 vaccine offers the hope of reducing neonatal transmission of HPV and decreasing the incidence and morbidity of recurrent respiratory (laryngeal) pappillomatosis (RRP) (212). A study to estimate the public health effects and cost-effectiveness of vaccination with Gardasil 9 in Germany indicated that immunization of boys with the 9-valent vaccine reduced the incidence of cervical cancer by $24 \%$ and anal cancers in males and females of 30 , and $14 \%$, respectively, while over a million cases of genital warts would be prevented in 100 years
(213). It is important to note that Gardasil-9 has not yet been approved for use in subjects who have received three doses of Gardasil or Cervarix (214). Moreover, Gardasil-9 is expected to be more cost-effective than HPV vaccines currently in use $(215,216)$.

\section{GTL001}

For eradication of cells infected with HPV, a therapeutic vaccine (bivalent) known as GTL001 is available. It is a fusion of HPV-16 E7 as well as HPV-18 E7 and detoxified adenylate cyclase (CyaA) of Bordetella pertussis binding to specific CD11b+ antigen presenting cells (APC) (217). The interesting feature is there is induction of $\mathrm{T}$ cell responses $(\mathrm{CD} 4+$ and $\mathrm{CD} 8+)$ in an antigen specific manner against the viral/tumor antigens. A recombinant CyaA that bears the HPV-16 E7 (antigen) when used for vaccination intradermally causes induction of a $\mathrm{T}$ cell response. This requires adjuvantation with a Toll-like receptor 9 agonist, i.e., CpG oligodeoxynucleotide (ODN1826). This ultimately results in elimination of tumors that express HPV16 E7 $(218,219)$. There are two GTL001 formulations, viz., a solution form and a powder form (which is more concentrated in nature) adjuvanted with imiquimod cream. The formulations have been tested in a clinical trial (phase I) and both are found to be safe and induced E7-specific CTL responses (159).

\section{9-Valent HPV Vaccine}

The safety as well as efficacy of the 9-valent vaccine providing protection against HPV types $6,11,16,18,31,33,45,52$, and 58 has been proven recently. This will help further in reducing the incidences of infection due to HPV along with the cancer related to the virus. Moreover, a herd immunity is generated for providing indirect protection to individuals that are unvaccinated (220). In boys as well as girls in the age group of 915 years, geometric mean titer (GMT) (non-inferior) is generated by 9 -valent vaccine $(208,221,222)$. The vaccine efficacy is proven also in 16-26 years age group of males (223).

\section{Safety of the Currentluy Used HPV Vaccines}

Safety of HPV vaccines was studied in both clinical trials before they were licensed and through post-licensure surveillance programmes (224-233). Like any other vaccines administered by intramuscular route, the HPV vaccinees may get inflammation (pain, erythema, swelling and pruritus) at the injection site. The other side effects include pyrexia, headache, chill, weakness, malaise, myalgia, and joint pain. These HPV vaccine-related adverse effects (AEs) usually occur from day 1 to day 15 after vaccination and mostly are mild; the vaccines are believed to be well tolerated in girls, boys and young women (234). Nevertheless, serious HPV vaccine related AEs that required hospitalization occurred in vaccinees of 9-valent HPV vaccine including asthmatic attack in a 10-year-old boy who had experienced seasonal allergy and bronchial asthma; high fever $\left(>38^{\circ} \mathrm{C}\right)$, body pain, headache, and malaise in a 26 -year-old woman; and occipital headache with photophobia, nausia and chill in a 23-year-old woman (234). In a large cohort study of $>2$ million young girls (aged 13-16 years) between 2008 
and 2012 in France of which 37\% received HPV vaccine, autoimmune diseases (AID) occurred in 4,096 subjects during the follow-up time (mean of 33 months). The incidence of AID was not increased after HPV vaccination, except GuillainBarre syndrome (GBS) which was found in 1.4 per 100,000 vaccinees versus 0.4 per 100,000 non-vaccinated subjects (232). No increase risk of GBS was observed following HPV vaccination in England (235). A systemic review and meta-analysis of 11 studies did not find any evidence of increased demyelinating diseases after HPV vaccination (233). However, at least 10 cases of neurological events were reported worldwide after HPV vaccination (236-241). A case-control epidemiological study of the vaccine adverse event reporting system (VAERS) database was undertaken to evaluate the risk for reported autoimmune adverse events following quadrivalent HPV vaccination (242). Cases with gastroenteritis, rheumatoid artritis, thrombocytopenia, SLE, vasculitis, alopecia, CNS demyelinating conditions, ovarian damage, or irritable bowel syndrome were significantly more likely than control to have received quadrivalent $\mathrm{HPV}$ vaccine (242).

Safety of HPV vaccines in pregnancy or immediately preconceptually has been reviewed (230). The HPV vaccination concerns were not only the maternal safety, but also (and more) on the teratogenicity and other fetal adverse events (AEs) following HPV vaccination, including spontaneous miscarriage, preterm birth, congenital malformations, and fetal decease. Pooled results from 11 studies which compared 16,142 women who received at least one dose of either bivalent $(2 \mathrm{vHPV}$, Cervarix $\left.{ }^{\circledR}\right)$ or quadrivalent $\left(4 \mathrm{vHPV}\right.$, Gardasil $\left.{ }^{\circledR}\right)$ vaccine, with 13,811 girls/women who received control vaccine (hepatitis A vaccine) indicated that the AEs in women who received the HPV vaccine were not greater than the controls, among the age groups $10-14,15-25$, and $>25$ years and the follow-up periods $0-7,7-$ 12 , and $>12$ months. For the fetal safety, none of the studies reported a significant increased rate of spontaneous abortion and other fetal outcomes in overall subgroup analyses (e.g., age, interval of time of conception and nearest vaccination, number of vaccinations) compared with controls. The conclusion was the risk of AEs during pregnancy is unrelated to HPV vaccination before or during pregnancy (230).

\section{THERAPEUTIC APPROACHES TO HPV-INDUCED DISEASE}

Currently, there are no HPV therapies available. Removal of the abnormal tissue by surgical operation is currently the recommended cure for cervical dysplasia. Removal of the affected tissue, e.g., cervical conizations, however, can lead to premature births. Thus, development of non-invasive treatment therapies for HPV-induced cancers is needed, and therapeutic HPV vaccines are a promising strategy $(243,244)$.

One study demonstrated the therapeutic potential of curcumin in high-risk HPV-infected oral cancer cells. Curcumin down-regulated HPV transcription by suppressing the cellular transcription factors AP- 1 and NF- $\kappa$ B and selectively inhibited E6 oncogene-mediated p53 degradation during carcinogenesis in HPV-16-positive oral cancer cells (245-248). Another study showed that certain cervical cancers did not express HPV oncogenes E6 and E7, and these were considered HPV-inactive tumors because they showed increased $W N T / \beta$-catenin and sonic hedgehog signaling, decreased DNA methylation, enriched non-synonymous somatic mutations specifically targeting the TP53, ARID, WNT, and PI3K pathways. Hence, these tumors can be treated by therapies targeting WNT, PI3K, and/or TP53 mutations (249).

The regulatory activity of the immune system is influenced by either chemotherapy or radiotherapy and in tumor models of mice in combination with vaccination can increase the efficacy of $\mathrm{T}$ cell-based immunity against HPV infection (250). The lesions induced by HPV (that are of lesser risk and shows infestation with regulatory $\mathrm{T}$ cells) can be successfully treated by the use of cyclophosphamide at low dose thereby altering the local environment of the immune system. In recent past, properly planned randomized trial has been introduced in patients with cervical cancer that shows metastasis to compare solely chemotherapy versus chemotherapy combined with a long synthetic peptide of HPV-16. Adoptive cell therapy (ACT) or antibody based-therapeutic approaches have been proven to be successful for treatment of patients with melanoma $(251,252)$. Earlier, it was evident from various sources that effector $\mathrm{T}$ cells that are specific to HPV can be obtained with consistency from cervical cancer patients. By the significance of local microenvironment of HPV-induced lesions, there may be a shift in the local balance of immune effectors through treatment. For example, uses of cyclooxygenase 2 (COX2) inhibitors (through inhibition of prostaglandin E2 production) or inhibitors of transforming growth factor beta (TGF $\beta$ ) receptor kinase (type I), anti-IL-6 or anti-IL-10 antibodies may prove to be efficacious. Ultimately, the main goal is a suppression of regulatory $\mathrm{T}$ cells and a generation of an effective effector $\mathrm{T}$ cell microenvironment by identifying the combination that is optimum in enhanced trafficking of the immune effector cells and their efficiency at the affected site. This ultimately provides scope to the immunity induced by vaccination for effective eradication of lesions that are persistent. In this regard, a good example is the use of imiquimod for priming the microenvironment to clear successfully HPV induced-vulvar lesions that are immune-mediated $(253,254)$.

\section{Photodynamic Therapy}

For eliminating malignancies at an early Stage as well as for palliative treatment of cutaneous Tumors Along With Tumors of lungs and esophagus (at late stage), photodynamic therapy (PDT) is an option already approved by Food and Drug Administration (FDA) (255-258). PDT is another approach used widely to treat various cancers. Topical administration of PDT is considered to be most appropriate for cervical and vulval intraepithelial lesions (259). 5-Aminolevulinic acid (ALA)-mediated PDT to treat HPV-associated cervical condyloma has been evaluated for HPV-6, 11, 16, and 18. Complete remission was observed after 14 treatments in $98.2 \%$ of cases, resulting in an HPV clearance rate of $83.9 \%$, with no evidence of cervical structural changes. This indicates the efficacy and safety of the PDT (260). Topical ALAPDT has been found efficacious and well tolerated when used to 
treat high-risk HPV infections (259). A photosensitizer dye IR700 coupled with HPV VLPs, when exposed to cervical cancer cell lines and $690-\mathrm{nm}$ light causes necrosis-like cell death by inducing the influx of CD8+ and CD4+ T-cells into the treated tumors (261).

Hexaminolevulinate-mediated PDT has been found to be safe for treating cervical intraepithelial neoplasia (CIN) $(262,263)$. Immune cell infiltration is a striking feature of photodynamic therapy, and it forms the basis for treatment of neoplasms that are HPV-associated; especially in the case of vulvar intraepithelial neoplasia (VIN). In chronic VIN, there is an alteration of the immunological balance if photodynamic therapy is employed. This leads to clearance of virus as well as lesions (258). Nevertheless for treating HPV infection the effectiveness of antimicrobial photodynamic therapy (APDT) cannot be denied $(264,265)$.

\section{Cryotherapy}

For treating cervical intraepithelial neoplasia, the efficacy along with safety and acceptability of cryotherapy is well documented. The cure rate with cryotherapy is very high (266). In low as well as middle income countries, cryotherapy seems to be suitable. But the shortage of refrigerant gas creates hindrance in the application of cryotherapy for treating $\operatorname{HPV}(267,268)$. It is interesting to note that within a period of 3 months one-fourth of the infection due to high risk HPV (hrHPV) can be cleared by cryotherapy (269).

\section{Cytotoxic Agents}

A few cytotoxic agents, including podophyllin or trichloroacetic acid, have been used topically to remove genital warts (270), while 5 -fluorouracil has been used to a lesser extent because it elicits a strong inflammatory reaction (271). Anti-cancer agents, i.e., arsenic trioxide $\left(\mathrm{As}_{2} \mathrm{O}_{3}\right)$ and carboplatin target transcription factors AP-1 and NF- $\mathrm{kB}$, play important roles in the expression of HPV oncoproteins E6 and E7 $(272,273)$. Some immunomodulators like imiquimod have records of safety and efficacy in treating HPV-caused genital warts (274). Aspergillus, Gliocladium, and Penicillium species produce tricyclic alkaloid gliotoxin (275) and effectively reduce the proliferation of HPV18 infected cells by inducing Bax, caspase- 3 , caspase- 8 , and caspase-9 and suppressing Bcl-2 (276).

\section{Antiviral Drugs}

Cis-retinoic acid is used as adjunctive therapy for treating HPVinduced lesion of the larynx; but due to efficacy issues, the drug had been discontinued in patients suffering from recurrent respiratory papillomatosis (RRP) (65). At present, the most common drug used in adjuvant therapy of RRP is cidofovir. The drug is used at a concentration of $5 \mathrm{mg} / \mathrm{mL}$ with a dose up to the limit of $3 \mathrm{mg} / \mathrm{kg}$. Such concentration and dose regimen can be followed both in children as well as adults $(65,277-279)$. Cidofovir can also be administered through inhalation, and in the near future such inhalation therapy may provide scope further to perform research on the clinical ground (280). The expression of E6 as well as E7, has been reduced by cidofovir. This drug is also involved in the reduction of metastatic characteristics of tumor cells that are positive for HPV (281). Ribavirin and acyclovir have also been used from time to time, but their clinical efficacy is questionable (65). For reduction of the size of precancerous lesions of cervix (PLC), an essential oil (natural) containing drug known as anti-viral 2 (AV2) has been introduced. The drug contains various organic compounds, viz., geraniol, eugenol, nerolidol, and carvone which can confer a broad spectrum effect (both on oral administration or topical application). More than half of the size of lesion is reduced when AV2 is applied [(282), http://www.cesa-alliance.com/webapp/index. html, (268)]. Xinfuning (a recombinant human interferon $\alpha$ $2 \mathrm{~b}$ vaginal effervescent capsule), used to treat vaginal infections, enhances NK cell activity (283).

Both in vitro as well as in vivo, the activity of interferons (IFNs) against HPV is well proven. Due to the anti-viral activity, anti-proliferative nature and capability to generate host immune response, interferons are quiet noteworthy for treatment of HPV (284). For adjuvant therapy against papillomatosis of larynx, interferons are among the earliest agents to be adopted. Biphasic vesicles are used in recent time to deliver IFN- $\alpha$ topically that ensures its delivery locally for a prolonged period without much exposure systemically $(285,286)$. IFN- $\alpha$ co-administered with retinoids has shown promising results when used to treat cervical carcinomas (287). Combined therapy with IFN- $\alpha$ and ribavirin has been found to be effective against perianal and genital infection caused by HPV (288). Similarly, pegylated interferon along with ribavirin is useful for treating disseminated HPV infection (289). Treatment with IFN- $\alpha$ has been shown efficacious in reducing the rate of condyloma recurrence (284).

\section{Herbal Medicines}

In the Chinese herbal medicine system, several plants with anti-HPV activity have been identified. The Chinese medicine named Paiteling, containing folium, sophora, cnidium, gall, and javanica oil, inhibits HPV by destroying mitochondrial and other membranes to cause necrosis (290). Carrageenan isolated from red algae, is known to bind HPV virions and inhibit postattachment entry (291). Carrageenan gel as a sexual lubricant has shown efficacy in preventing infection with an HPV-16 pseudovirus (292).

Significant activities against HPV are shown by certain Chinese medicines (traditional) which are used for preventing as well as treating cancer in relation to HPV. The inhibitory effect of Chai $\mathrm{Hu}$ (from roots of Bupleurum chinense) on infection due to HPV is well known. This particular medicine has been found to interfere with DNA expression of HPV in genital warts. Youdujing is another medicine that is responsible for reversion of the cervical lesion function in patients having a greater risk of infection due to HPV (293-295). Inhibition of the risk of infection due to HPV can be done by Paiteling consisting of folium as well as javanica oil as essential components. Moreover, this medicine also contains gall and cnidium as well as sophora all of which can ultimately cause the specific destruction of the mitochondria as well as other biological membranes ultimately resulting in degeneration of cells along with programmed cell death (290). Treating with fraction of Pinellia extract causes reduction of the expression of mRNA and level of protein of 
HPV E6 whereas there is increase in the protein level as well as mRNA of p53 in cancer cells of the cervix. The antitumor effect of the Pinellia extract fraction is thought to be due to the down-regulation of expression of HPV E6 gene and p53 gene upregulation $(296,297)$. There is reduction of viral load along with improvement of cytological as well as pathological results in patients with infected cervix by application of Zibai gel (298). Youdujing cream is clinically effective and for condyloma acuminatum it is a popular choice. The amplification of HPVDNA is inhibited as is evident by in vitro experiments to reveal the therapeutic efficacy of Youdujing in lesions of the genital tract (299-301).

\section{Ranpirnase RNAse}

Ranpirnase RNAse is a peptide that cleaves double-stranded RNA (dsRNA). It can eradicate HPV from cultured cells. This drug has been used to treat several malignancies with few side effects, even with a transiently increased serum creatinine level. Three different formulations containing $1 \mathrm{mg} / \mathrm{mL}$ ranpirnase were applied topically to genital or anal warts of male volunteers, and it was moderately tolerated in these patients with a mean healing time 30 days (302). HPV-11 is the HPV type primarily responsible for genital warts, and ranpirnase is effective against this type, as well as HPV-16. In a patent application by Sulley and Squiquera (303), the enzyme is formulated with a vehicle that does not affect its activity and can be applied topically to genital warts for potential approval as a sexual lubricant. A close variant of ranpirnase has been granted with patent, which contained three mutations (I11V, D20B, and S103R) was found non-toxic and well-tolerated in humans (304).

\section{RNA Interference (RNAi)-Based Therapies}

For cancer therapies based on RNAi, an ideal model system is the $\mathrm{HPV}$-induced tumors because there is expression of E6 as well as E7 (the oncogenes responsible for causing cervical cancer) only on tumor cells (305). As far as the RNAi therapy is concerned, any of the non-structural (early genes) or structural genes (late genes) of HPV can be targeted (306). The two siRNAs targeting the E6/E7 promoter and E7 transcripts, and thereby knocking down E6 and E7 mRNAs elicit high levels of TP53 expression. Subsequently, apoptosis is induced in cell lines of cervical cancer origin which are positive for HPV-16 (307-309). Nine siRNAs designed by Chang et al. (310) were found to target E6 or E6/E7 mRNA of HPV-16 and 18 specifically, and intratumoral administration of these siRNAs resulted in induction of cervical cancer cell apoptosis. In mice (immunocompetent), there is development of tumors (small sized) when HPV-16 E7 siRNAs are used for pre-treating tissue culture-1 cells of murine origin (311). In Caski cells, there may be suppression of tumors if siRNAs are injected intratumorally (312). HPV-siRNA plasmids were constructed using a pTOPO-U6 or pTOPO-U6II vector. HPV-16 and 18-type siRNA libraries have been screened for potent siRNAs, which will subsequently be validated in in vitro and in vivo experiments (313). However in the clinical setting, the success of RNAi-based therapies is limited (314). It is further interesting to note that the cisplastin sensitivity of cancerous cells is increased when siRNA is used to target oncogenes of HPV as it leads to reactivation of p53 pathway (305).

\section{Localized Immunomodulation}

For clearance or suppression of infection due to HPV immunologically in a normal manner, the usefulness of localized immunomodulation has already been proven. The Aldara cream contains an active agent called imiquimod (a Toll like receptor-7 agonist) and this cream can be used topically. There is release of interferons (type I) along with proinflammatory cytokines due to activation of macrophages, dendritic cells along with keratinocytes by imiquimod $(315,316)$. Imiquimod enhances immunity by activating a Th1 response (317). Imiquimod causes side effects that include irritation at the site of application. Green tea leaves contain an extract known as polyphenon E (sinecatechins) that causes immunomodulatory stimulation of the clearance of the virus (318).

\section{Immunotherapy}

Immunotherapy has emerged as an adjunctive treatment for standard cancer treatments (surgery, radiotherapy and/or chemotherapy). Substances used in the cancer immunotherapy include non-specific immune stimulators, cytokines, monoclonal antibodies and adoptive or engineered autologous immune cells, mainly $\mathrm{T}$ cells. The same strategies canbe applied for treatment of HPV-induced cancers. Bacillus Calmette-Guerin (BCG) given via catheter into bladder with tumor mass in several cycles over several months reduces the otherwise high recurence and progression rates of bladder cancer by causing stimulation of effective immune response against cancer cells (American Cancer Society). Cytokines (such as interferons) enhance immune system aganst cancers. Therapeutic antibodies, nakedly or conjugated (loaded) with radioisotope, toxin, or drug, kill directly the cancer cells. Some antibodies recognizes molecule which is highly expressed on cancer cells such that the cells are better seen by the effector immune system for antibodydependent cell-mediated cytotoxicity (ADCC) or complementmediated cell lysis. Anitbody binding to cell surface receptor can also cause inhibition of downstream cell signaling and prevent cancer cell shading of decoy to increase effectiveness of the host immune system. Monoclonal antibodies in the form of bispecific $\mathrm{T}$ cell engager (BITE) bind to cancer cell and effector $\mathrm{T}$ cell simultaneously and bring them into vinicity for increasing the effector cell effectiveness. Antibodies to immune checkpoint molecules on effector $\mathrm{T}$ cells such as programmed cell death-1 (PD1) and cytotoxic lymphocyte antigen-4 (CTLA-4) restores the effector $\mathrm{T}$ cell activity which is suppressed by ligands highly expressed on the cancer cells leading consequently to not only cancer cell death, but also death of regulatory $\mathrm{T}$ cells in the tumor environment. Anti-PD$1 / \mathrm{OX} 40$ monoclonal antibody treatment increased $\mathrm{CD} 4^{+}$and $\mathrm{CD}^{+}$cells and decreased immunosuppressive CD4+FoxP3+ regulatory $\mathrm{T}$ (Treg) cells (319). Chimeric antigen receptor $\mathrm{T}$ cells (engineered patient's own T cells) (320) and cytokine activated adoptive/autologous tumor infiltrating lymphocytes (321) are effective in several cancer immunotherapy. These options canbe adopted for treatment of HPV-mediated cancers. 
Two monoclonal antibodies against the L1 protein of HPV-16 have been produced for diagnostic and therapeutic purposes (322). Anti-HPV 16/18 E6 (C1P5; Abcam) administered repeatedly induced apoptosis of HPV-related cervical cancer (323).

\section{Miscellaneous Therapies}

Cimetidine has been found to be useful for papillomas of conjunctiva (in case of ocular surface infection due to HPV). It augments the immune system by inhibition of $\mathrm{T}$ suppressor cell function and enhances delayed-type hypersensitivity (DTH) (324). One interesting immunomodulator is dinitrochlorobenzene (DNCB) which may cause induction of DTH response; thereby causing regression of tumor. It has got direct application and is useful in case of surgical failure (325). There is reduction in the rate of recurrence of HPV-induced tumors by use of radiation therapy. Additionally chemotherapy eye drops are found to be efficacious in clinical various trials (326). It is also interesting to find that there is effective inhibition of the growth of tumors (expressing HPV
E6 as well as E7) by cetuximab when grafting is done in severe combined immunodeficient (SCID) mice (327).

An overview on various therapeutic approaches available for treatment of HPV is depicted in Figure 3. Different patents recital to the HPV are provided in Table 1 and the various therapies available to treat HPV are summarized in Table 2.

Last but not the least this review is a unique/comprehensive review which highlights the various advances in developing vaccines (both prophylactic and therapeutic) and therapeutic regimens along with recent patents coverage on drugs, vaccines and therapeutics against HPV that will help the scientists and medical practitioners to prevent, treat and facilitate the eradication of the malignancies in relation to HPV in an effective and more promising manner. Moreover, the mind of researchers will be more innovative to combine therapeutic vaccines against HPV with radiation and chemotherapy for designing better control measures along with adopting advanced therapeutic approaches to counter HPV infections and the associated cancerous conditions. The advanced information on HPV vaccines and therapeutics presented

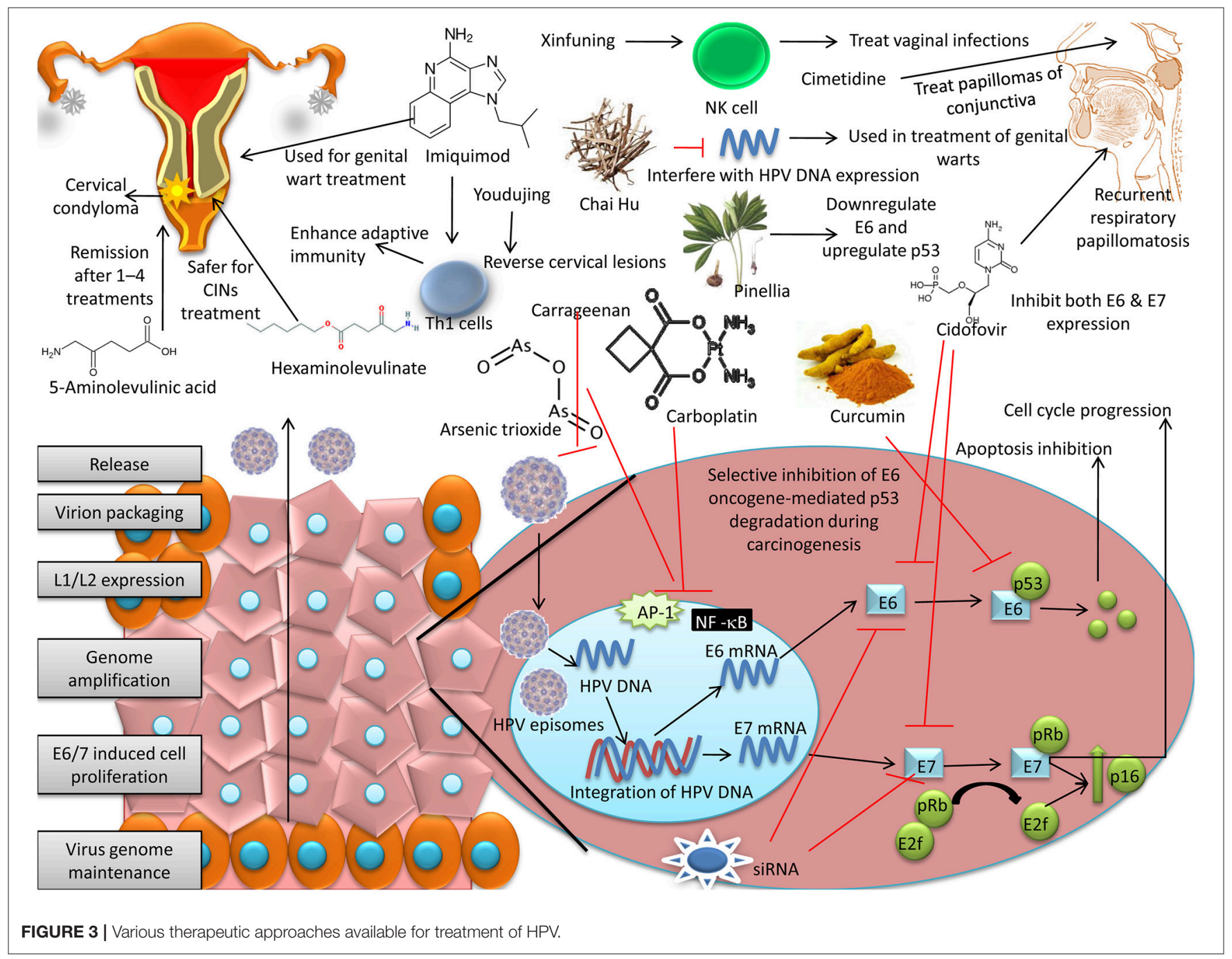




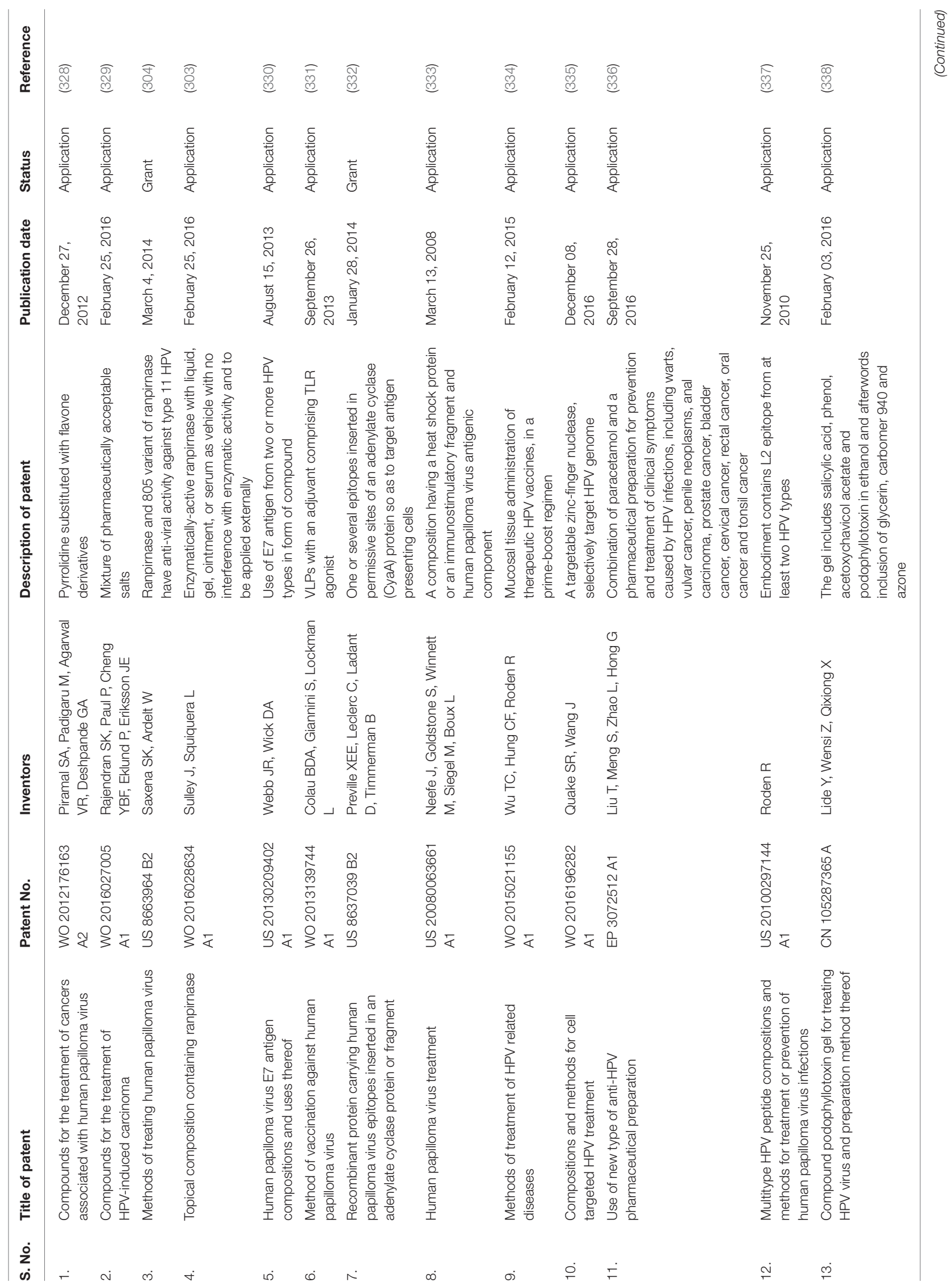




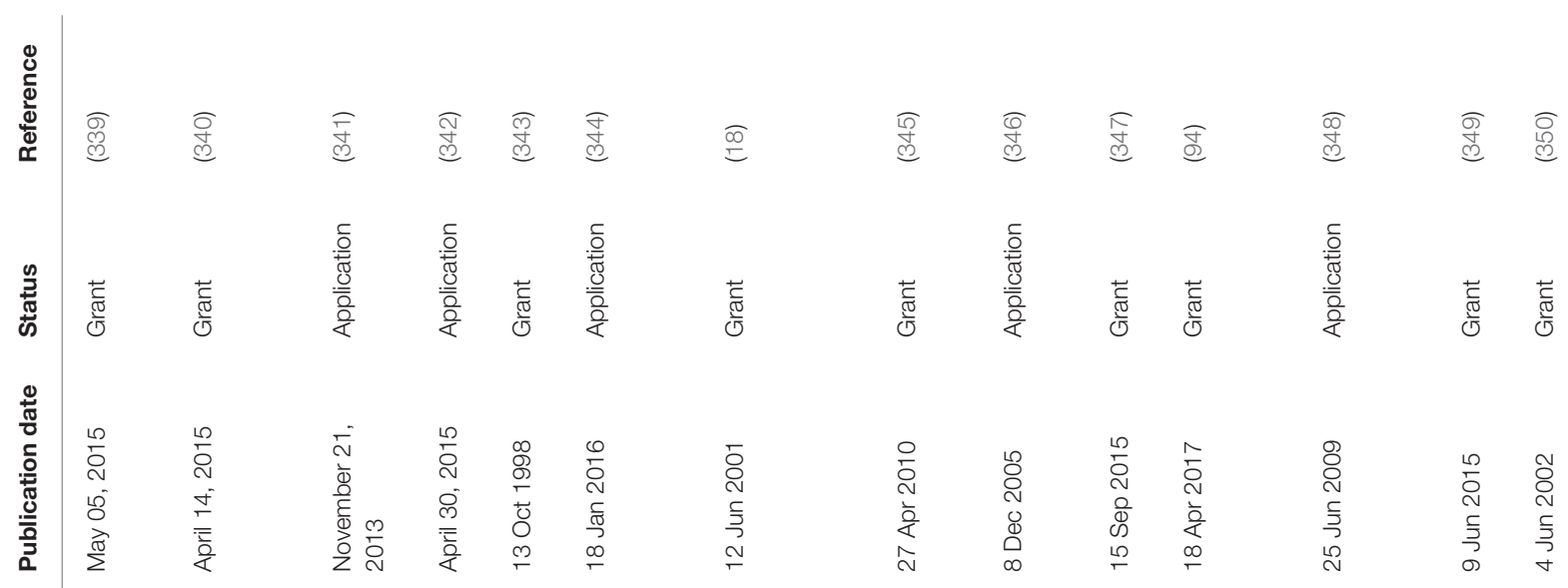
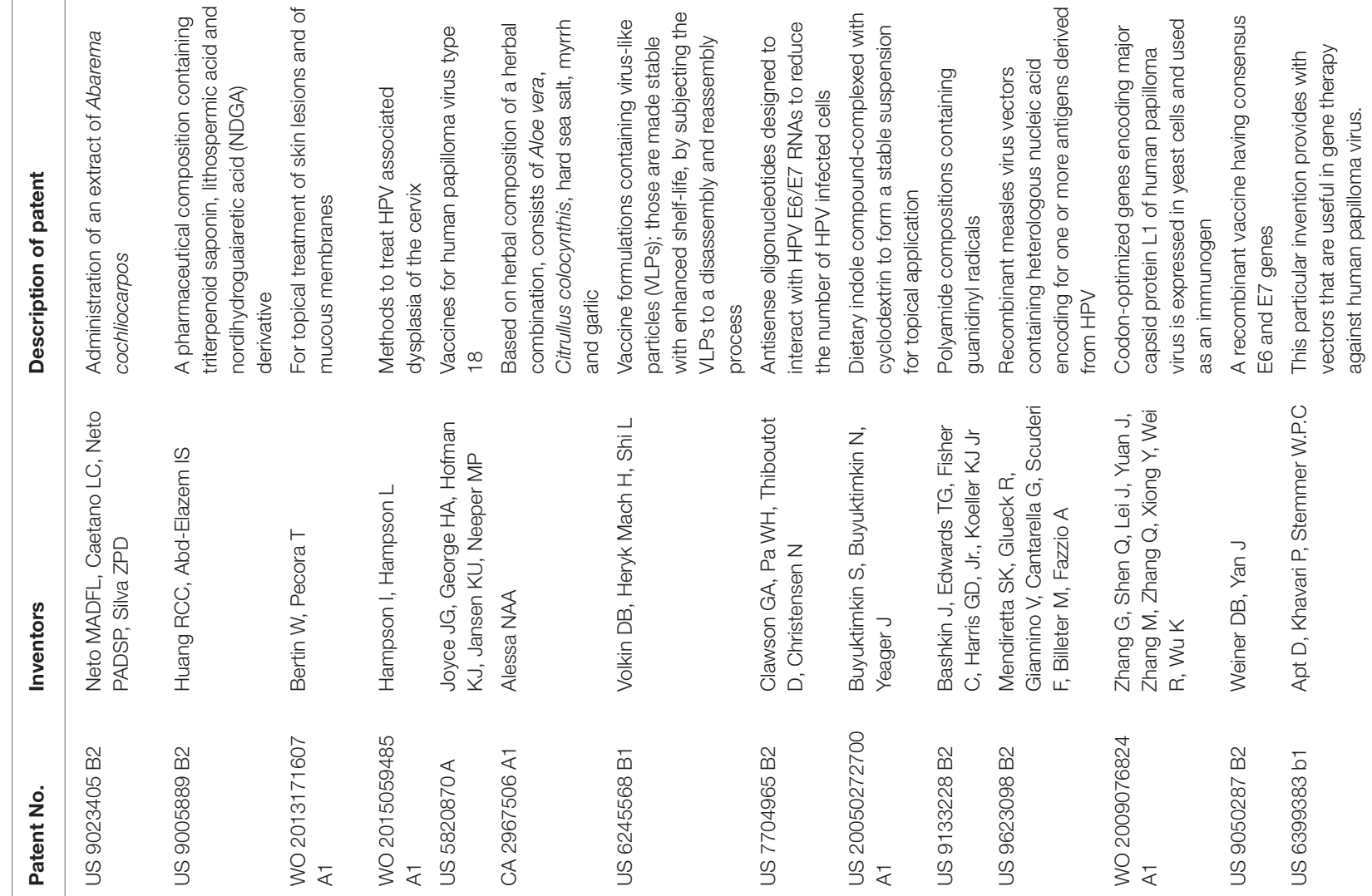

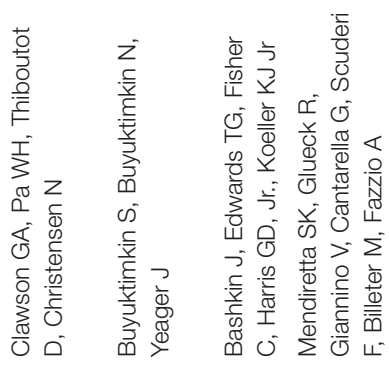

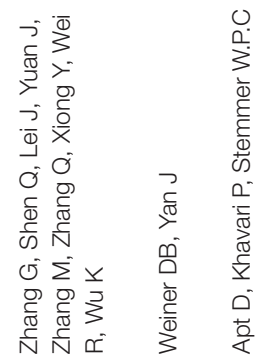

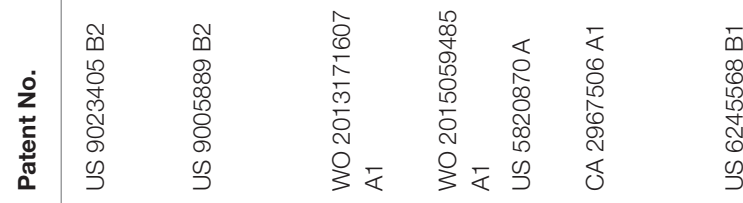

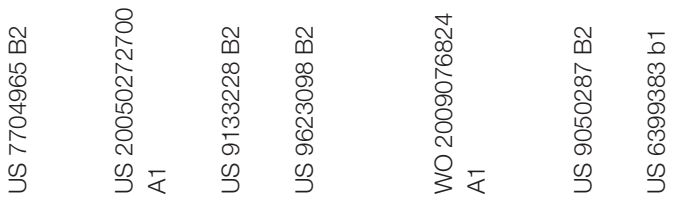
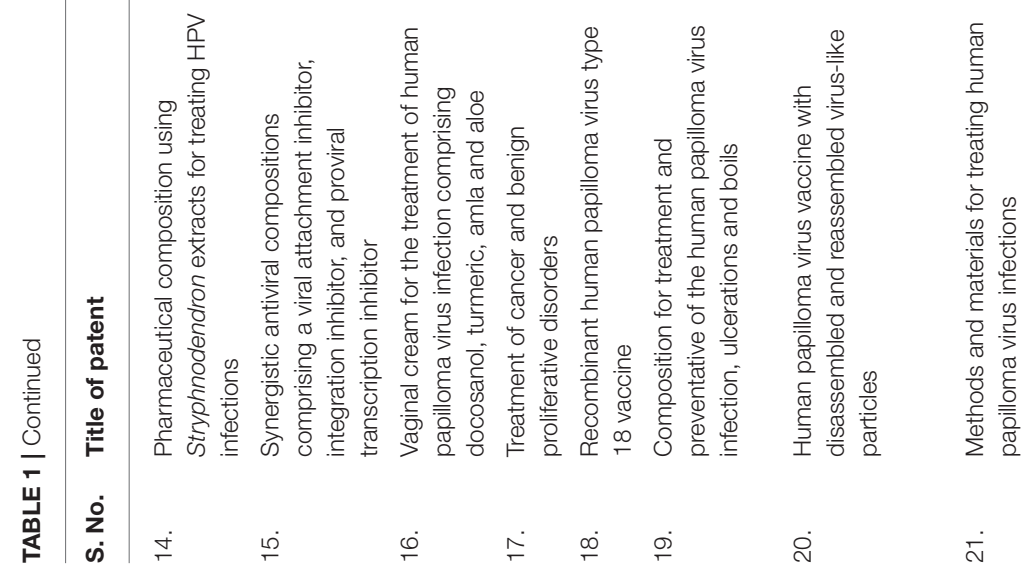

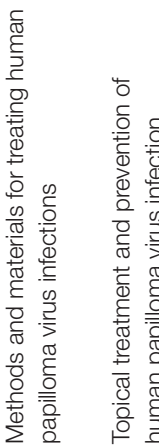
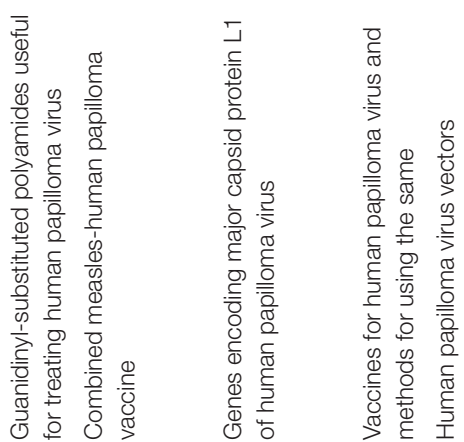

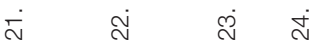

வேं 


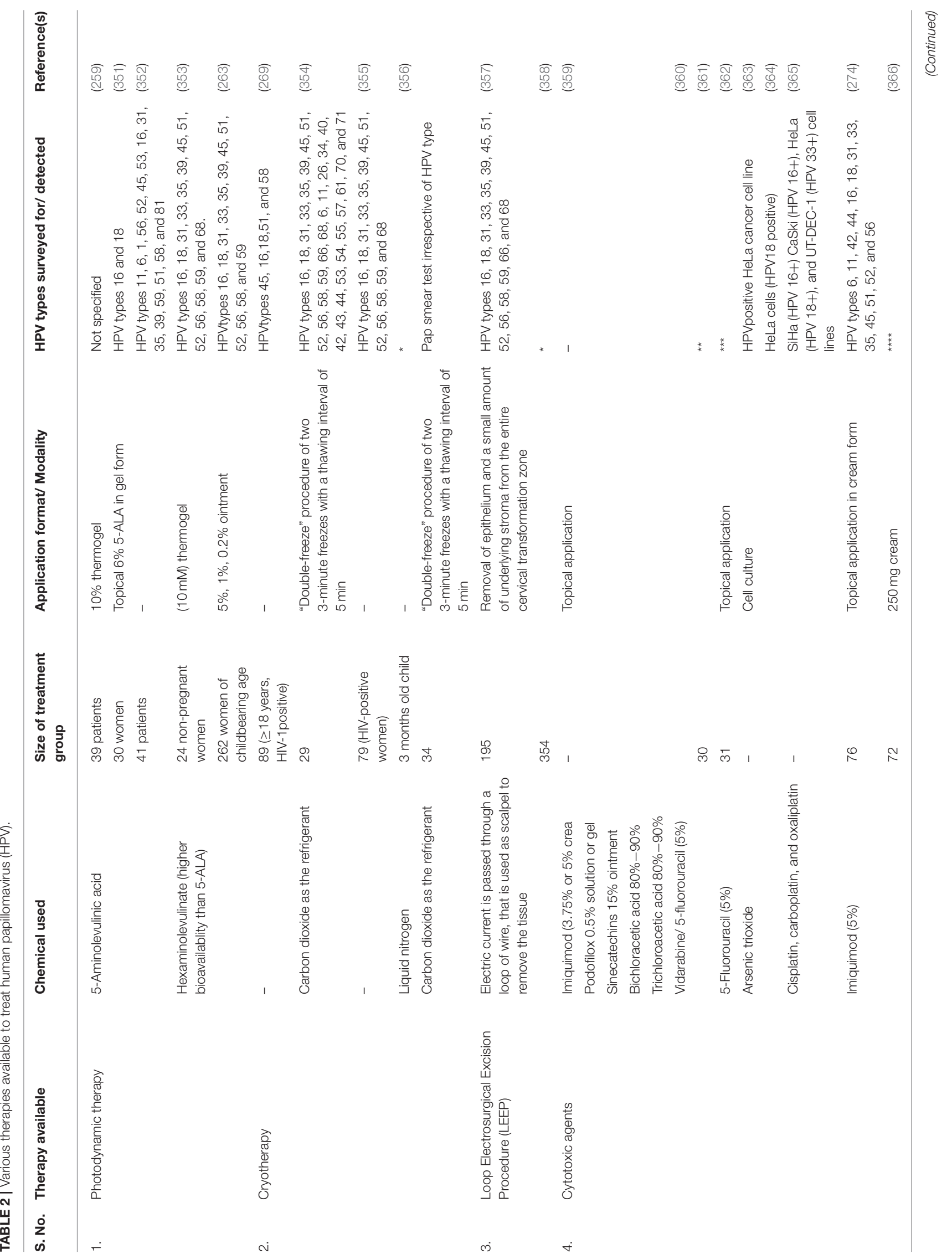




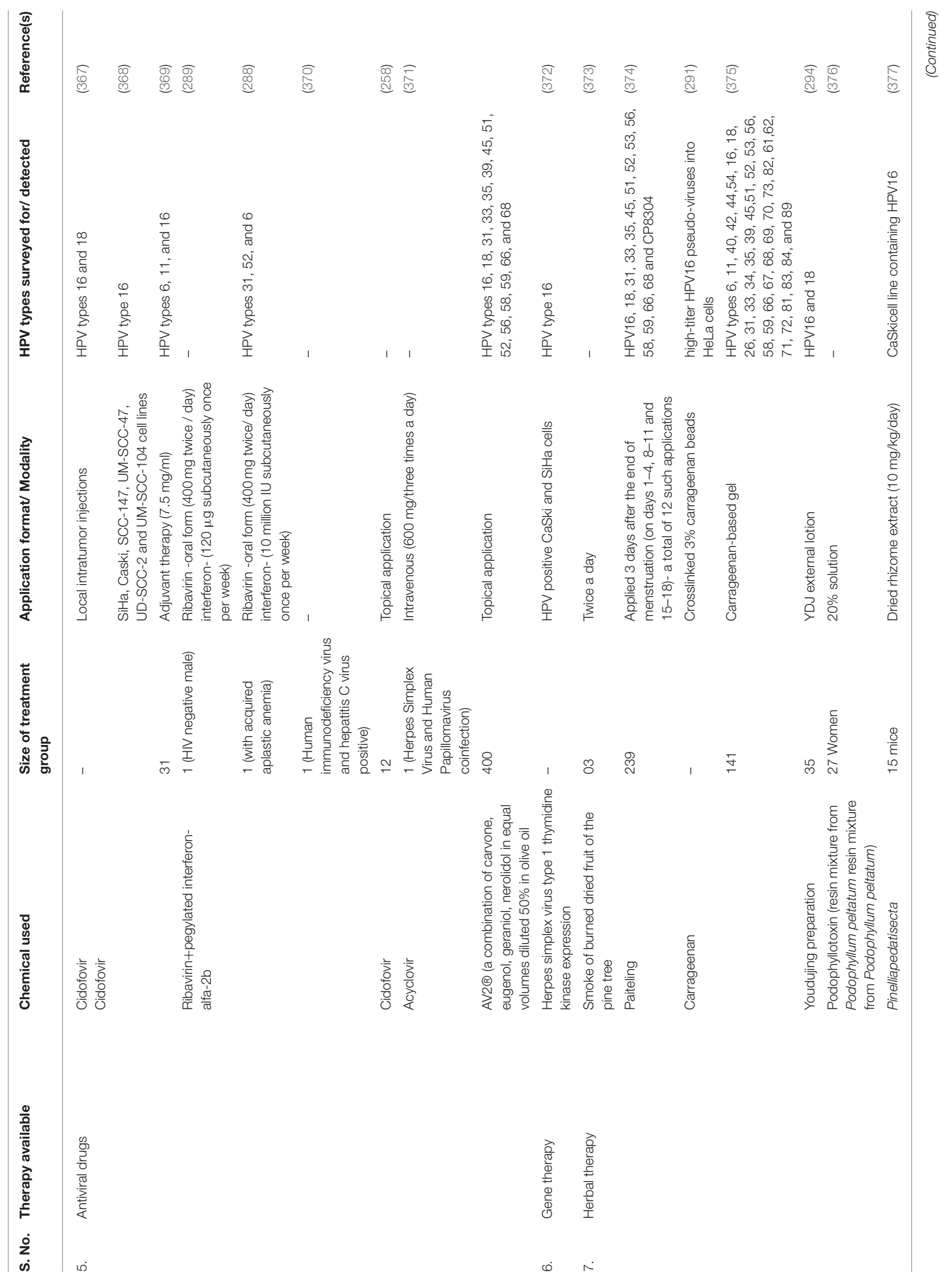



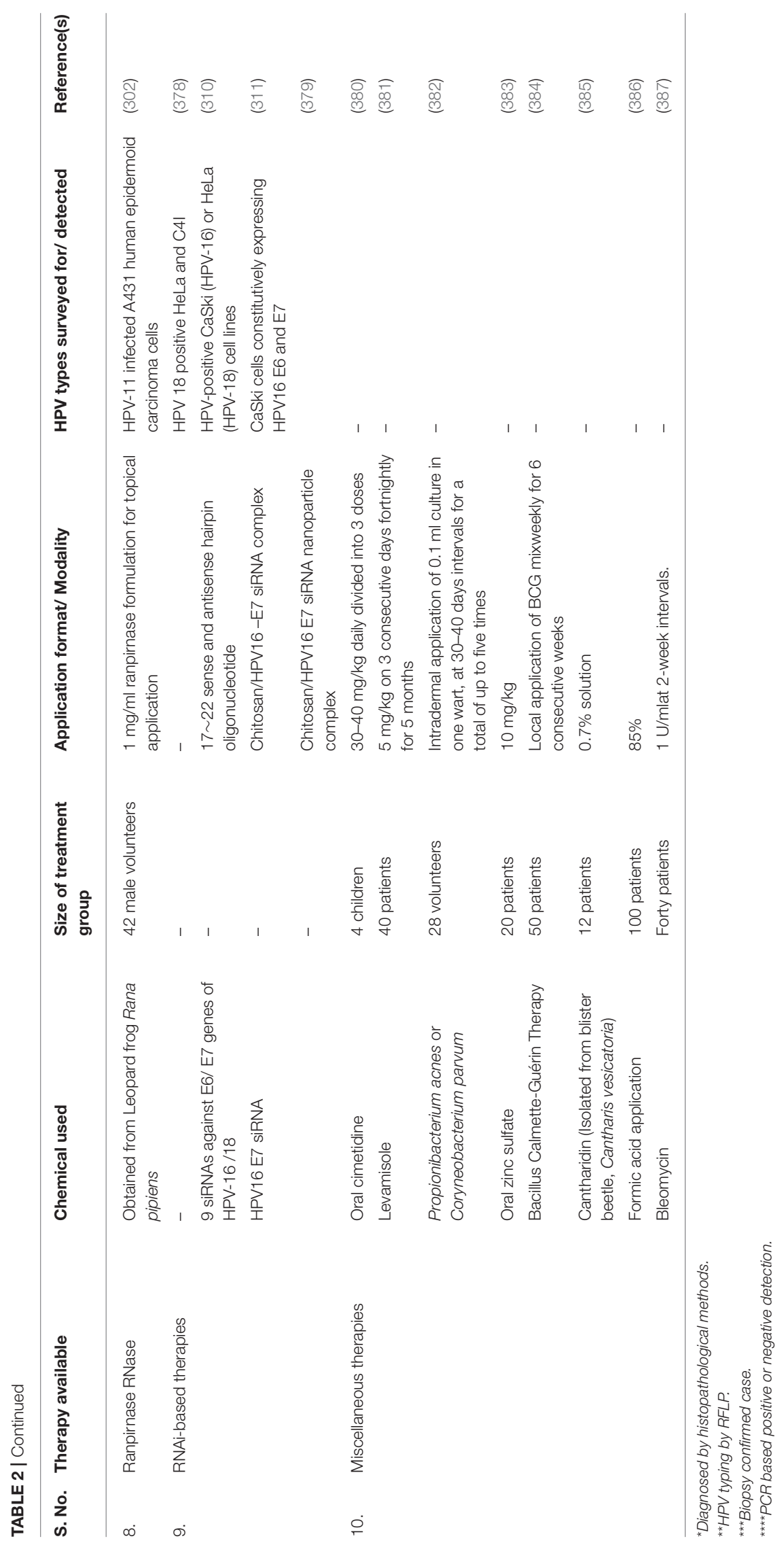
in this review compilation along with carrying out more researches in futuristic prospects in the right directions would pave way to design and develop suitable prophylactic and therapeutic vaccines, drugs and treatment modalities delivering clinical outcomes in an improved manner and to combat HPV and its cancerous conditions effectively at global level.

\section{CONCLUSION AND FUTURE PROSPECTS}

This review highlights the advances in designing prophylactic and therapeutic vaccines as well as treatment regimens against human papilloma virus (HPV) to encourage the development of effective vaccines and therapies against this important disease. For prevention of HPV infection, the use of topical microbicides has been explored widely. For instance, like the use of carrageenan to prevent genital infection due to HPV, several patent applications for formulations are pending which comprise several natural components, such as Aloe vera, turmeric, Citrullus colocynthis, hard sea salt, myrrh, and garlic to treat HPV. More clinical trials are needed to be conducted to explore the utility of topical microbicides. Studies through mathematical modeling have predicted that vaccination can maintain the antibody levels (especially against HPV-16 and 18) at a much higher level than the level reached due to natural infection for a period of minimum two decades after vaccination. So it can eliminate the requirement of booster dose for a long period. Derivation of the consensus sequence for E6 and E7 genes, followed by codon optimization of these genes and their use as immunogen will pave the way for effective prophylactics. Three commercially available prophylactic vaccines show sufficient efficacy; however, attempts to develop next-generation vaccines that are inexpensive, effective, stable, and that show broad crossneutralizing immunity are in progress. Recombinant vaccine immunogens based on transgenic plants are an attractive and potentially affordable alternative to vaccines by injection. For example, edible plants can be grown locally and distributed easily without special training or equipment. Approved HPV vaccines based on recombinant VLPs of important high-risk HPV L1 major capsid antigen are effective in controlling HPV infections, but do not have therapeutic applications or protect against cutaneous infections. There are studies to evaluate alternative approaches to deliver current vaccine in a safer and affordable way. For example, microneedle deliveries of lyophilized HPV pseudovirions are thermostable and have been tested in a murine model. Also, acceptance of HPV vaccines has been hindered by many factors associated with place of residence, culture, and economics. Administration of these vaccines has been virtually non-existent in developing countries, mainly because of their extremely high costs and the technical challenges of vaccination, which require multiple doses over a 6-month period (388). Also, refrigeration is needed during shipping and storage, introducing logistical difficulties in areas that lack adequate infrastructure. HPV vaccines cost approximately US $\$ 450$ (Gardasil) and US $\$ 495$ (Gardasil 9) in the U.S. for the complete course of three injections. Therefore, second-generation HPV vaccines are needed to reduce the costs of vaccine production and increase immunization schedule feasibility.

A subdominant neutralizing epitope in the HPV L2 protein is an alternative approach to produce recombinant VLP antigens. This well-conserved linear neutralizing HPV epitope, which is located at the amino terminus of the L2 protein, may be exposed while the virus is on the basement membrane during infection. Attempts are being made to formulate more stable VLPs for immunization, and in fact, VLPs which are subjected to a disassembly and reassembly process have been found to be more stable, and the patent has been granted to the technology. Another alternative antigen for use in HPV vaccines is the pentameric subunit or capsomere of the L1 protein that has essential neutralizing epitopes to induce an immune response to protect against HPV. Recombinant capsomeres expressed in E. coli represent one important approach to reducing manufacturing costs. Studies in animal models have reported that HPV capsomeres alone induce lower antibody titers than VLPs. Therefore, this approach will require further optimization for increased antibody titers. However, the pentamers can be lyophilized for greater thermostability, suggesting the potential for formulations that can be shipped and stored without refrigeration (389). Thus, use of capsomeres is an attractive and affordable option for developing second-generation HPV vaccines (389).

On the other hand, production of combined preventivetherapeutic antigens, focusing on fusions of L2 with E7, or both E6 and E7, is in the early stages, and their therapeutic effectiveness has not been demonstrated. However, these therapeutic vaccines have shown some promise in some early clinical trials. Curcumin has also shown the potential to prevent HPV-associated oral cancers by selectively inhibiting E6 oncogene-mediated p53 degradation. Apart from vaccination, several therapeutic approaches are also becoming popular nowadays to counter HPV, and if given in conjugation with vaccines, the disease may be combated in a better way. Among some treatment strategies, a photodynamic therapy which uses 5-aminolevulinic acid has been tested against HPV-6, 11, 16, and 18 and a higher clearance rate (83.9\%) has been observed, without affecting the cervical tissue morphology. Topical application of few cytotoxic compounds including podophyllin, arsenic trioxide, carboplatin or trichloroacetic acid also has been suggested to remove genital warts. Interferons and immunomodulators like imiquimod also have been tested for their efficacy in removing genital warts and found useful. Antivirals like cidofovir, ribavirin, and acyclovir have been tested against HPV, but cidofovir has been used widely, and since it can be administered through inhalation, additional benefits are present for using it in clinical applications. Ranpirnase RNase enzyme cleaves dsRNAs, and in the form of a topically applicable ointment, it has proved effective in treating anal warts. The treatment modules encompassing the use of antisense RNA are still in infancy but have shown some promise in therapeutic efficacy.

For HPV vaccines, pre-adolescent girls are the primary target but evaluation of the cost effectiveness of vaccination of other 
groups needs to be done. For certain candidate vaccines entering phase III trial, a viable vaccine (prophylactic) against a few types of HPV may become available in a less period of five years. For complementing conventional therapy designing of the therapeutic vaccines (under investigation) are done mostly. However, the extent of benefit or the cost at which such benefits can be offered to the women are not yet clear. Clearing of the earliest stage of infection due to HPV by therapeutic vaccines is possible but is less developed. Certainly such vaccines hold promises to reduce the suffering as well as cost of treatment associated with disease of the cervix. For precancerous lesions, it is, however, crucial to continue the process of development of accurate screening as well as treatment plans and programs as there is forward movement of the process of vaccine development.

No one can deny the fact that vaccination against HPV has proven to be a landmark in the history of prevention of cancer. The incidence of HPV-induced cervical cancer will reduce drastically if adolescent girls are immunized, and this must be the priority not only in the industrialized world, but also in developing nations where it is sometimes impossible to detect the precancerous lesions at an early stage. It is however unfortunate that even in the developed nations of the Western world, the screening to detect cervical HPV-induced cancer is not performed on a regular basis. In this context, implementation of immunization of girls in every nation universally is of immense benefit. To succeed in such aspect of prevention of $\mathrm{HPV}$ infection especially in women, convincing the parents as well as their daughters is a top priority. Similarly, vaccination in homosexual males is of utmost relevance concerning prevention of HPV in the community. But to assess the sexual orientation

\section{REFERENCES}

1. Forcier M, Musacchio N. An overview of human papillomavirus infection for the dermatologist: disease, diagnosis, management, and prevention. Dermatol Ther. (2010) 23:458-76. doi: 10.1111/j.1529-8019.2010.01350.x

2. Brianti P, De Flammineis E, Mercuri SR. Review of HPV-related diseases and cancers. New Microbiologica. (2017) 40:80-5.

3. Palefsky JM, Hirsch MS, Bloom A. Human Papillomavirus Infections: Epidemiology and Disease Associations. Waltham: UpToDate (2018). Available online at: https:/www.uptodate.com/contents/humanpapillomavirus-infections-epidemiology-and-disease-associations (Accessed June 16, 2018).

4. Bonanni P, Bechini A, Donato R, Capei R, Sacco C, Levi M, et al. Human papilloma virus vaccination: impact and recommendations across the world. Ther Adv Vaccines (2014) 3:3-12. doi: 10.1177/2051013614557476.

5. Stanley M. Immunobiology of HPV and HPV vaccines. Gynecol Oncol. (2008) 109:S15-21. doi: 10.1016/j.ygyno.2008.02.003

6. Li N, Franceschi S, Howell-Jones R, Snijders PJ, Clifford GM. Human papillomavirus type distribution in 30,848 invasive cervical cancers worldwide: variation by geographical region, histological type and year of publication. Int J Cancer. (2011) 128:927-35. doi: 10.1002/ijc.25396

7. Fardows J, Nehar N, Laskar N, Joly SN. Human Papilloma virus vaccine: future of cervical cancer prevention. J Enam Med Coll. (2016) 6:157-60. doi: 10.3329/jemc.v6i3.29683

8. Zur Hausen H. Papillomaviruses and cancer: from basic studies to clinical application. Nat Rev Cancer. (2002) 2:342-50. doi: 10.1038/nrc798 in every male is somewhat difficult for which universal male vaccination is essential. With the usage of efficient vaccination and application of potent therapeutics, the effective elimination of the disease is expected and in fact combinations of several therapies have helped people in getting rid of this ailment. For all these reasons, it is necessary for the public health authorities to remain proactive and at the same time innovative methods will also be required for financing introduction of HPV vaccine and advancing the development of potent therapeutics.

\section{AUTHOR CONTRIBUTIONS}

All the authors substantially contributed to the conception, design, analysis, and interpretation of data, checking and approving the final version of the manuscript, and agree to be accountable for its contents. $\mathrm{MD}, \mathrm{KD}, \mathrm{SH}$, and $\mathrm{RT}$ initiated this review compilation. SC, RK, AM, MP, and DK updated different vaccines and therapies. RK designed table. KK designed the figures. KD, HI, MD and WC reviewed, analyzed and edited.

\section{FUNDING}

This compilation is a review article written, analyzed and designed by its authors and required no substantial funding to be stated.

\section{ACKNOWLEDGMENTS}

All the authors acknowledge and thank their respective Institutes and Universities.
9. Bruni L, Barrionuevo-Rosas L, Albero G, Serrano B, Mena M, Gómez D, et al. ICO Information Centre on HPV and Cancer (HPV Information Centre). Human Papillomavirus and Related Diseases in India. Summary Rep. (2016).

10. Harper DM. Currently approved prophylactic HPV vaccines. Expert Rev. Vaccine (2009) 8:1663-79. doi: 10.1586/erv.09.123

11. Kash N, Lee MA, Kollipara R, Downing C, Guidry J, Tyring SK. Safety and efficacy data on vaccines and immunization to human papillomavirus. J Clin Med. (2015) 4:614-33. doi: 10.3390/jcm4040614

12. Harper DM, Williams KB. Prophylactic HPV vaccines: current knowledge of impact on gynecologic premalignancies. Discov Med. (2010) 10:7-17.

13. Ma B, Maraj B, Tran NP, Knoff J, Chen A, Alvarez RD, et al. Emerging human papilloma virus vaccines. Expert Opin Emerg Drugs. (2012) 17:46992. doi: $10.1517 / 14728214.2012 .744393$

14. Paul KT. "Saving lives": Adapting and adopting Human Papilloma Virus (HPV) vaccination in Austria. Soc Sci Med. (2016) 153:193-200. doi: 10.1016/j.socscimed.2016.02.006

15. Stillo M, Santisteve PC, Lopalco PL. Safety of human papillomavirus vaccines: a review. Expert Opin Drug Saf. (2015) 14:697-712. doi: 10.1517/14740338.2015.1013532

16. Villa LL. Prophylactic HPV vaccines: reducing the burden of HPV-related diseases. Vaccine (2006) 24:S23-S28. doi: 10.1016/j.vaccine.2005.09.001

17. Christensen ND, Reed CA, Cladel NM, Han R, Kreider JW. Immunization with viruslike particles induces long-term protection of rabbits against challenge with cottontail rabbit papillomavirus. J Virol. (1996) 70:960-5.

18. Volkin DB, Heryk, Mach H, Shi L. Human papilloma virus vaccine with disassembled and reassembled virus-like particles. US 6245568 B1 (2001). 
19. Turner TB, Huh WK. HPV vaccines: translating immunogenicity into efficacy. Hum Vaccin Immunother. (2016) 12:1403-5. doi: 10.1080/21645515.2015.1103936

20. Franco EL, Bosch FX, Cuzick J, Schiller JT, Garnett GP, Meheus A, et al. Knowledge gaps and priorities for research on prevention of HPV infection and cervical cancer. Vaccine (2006) 24:242-9. doi: 10.1016/j.vaccine.2006.06.038

21. Hildesheim A, Markowitz L, Avila MH, Franceschi S. Research needs following initial licensure of virus-like particle HPV vaccines. Vaccine (2006) 24:227-32. doi: 10.1016/j.vaccine.2006. 05.102

22. Hariri S, Markowitz L, Dunne E, Unger E. Population impact of HPV vaccines: summary of early evidence. J Adolesc Health (2013) 53:679-82. doi: 10.1016/j.jadohealth.2013.09.018

23. Markowitz LE, Dunne EF, Saraiya M, Lawson HW, Chesson H, Unger ER. Quadrivalent human papillomavirus vaccine: recommendations of the Advisory Committee on Immunization Practices (ACIP). Morb. Mort. Wkly. Rep. Recomm. Rep. (2007) 56, 1-24.

24. Kaarthigeyan K. Cervical cancer in India and HPV vaccination. Ind J Med Paediatr Oncol. (2012) 33:7-12. doi: 10.4103/0971-5851.96961

25. Pogoda CS, Roden RB, Garcea RL. Immunizing against anogenital cancer: HPV vaccines. PLoS Pathog. (2016) 12:e1005587. doi: 10.1371/journal.ppat.1005587

26. Tomar A, Kushwah A. Advances in human papilloma virus vaccines: a review. Int J Basic Clin Pharmacol. (2014) 3:37-43. doi: 10.1517/13543776.2011.551114

27. Kines RC, Zarnitsyn V, Johnson TR, Pang YYS, Corbett KS, Nicewonger JD, et al. Vaccination with human papillomavirus pseudovirus-encapsidated plasmids targeted to skin using microneedles. PLoS ONE (2015) 10:e0120797. doi: 10.1371/journal.pone.0120797

28. Setiawan D, Luttjeboer J, Pouwels KB, Wilschut JC, Postma MJ. Immunogenicity and safety of human papillomavirus (HPV) vaccination in Asian populations from six countries: a meta-analysis. Jpn J Clin Oncol. (2017) 47:265-76. doi: 10.1093/jjco/hyw192

29. Khan L. Human papillomavirus and the HPV vaccine: where are we today? Pediatr Ann. (2017) 46:e2-e5. doi: 10.3928/19382359-20161216-01

30. Frazer IH. Prevention of cervical cancer through papillomavirus vaccination. Nat Rev Immunol. (2004) 4:46-55. doi: 10.1038/nri1260

31. Leggatt GR, Frazer IH. HPV vaccines: the beginning of the end for cervical cancer. Curr Opinion Immunol. (2007) 19:232-8. doi: 10.1016/j.coi.2007.01.004

32. Stanley MA. Epithelial cell responses to infection with human papillomavirus. Clin Microbiol Rev. (2012) 25:215-22. doi: 10.1128/CMR.05028-11

33. Stanley M. Pathology and epidemiology of HPV infection in females. Gynecol. Oncol. (2010) 117:S5-10. doi: 10.1016/j.ygyno.2010.01.024

34. LaCour DE. Human papillomavirus in infants: transmission, prevalence, and persistence. J Pediatr Adolesc Gynecol. (2012) 25:93-7. doi: 10.1016/j.jpag.2011.03.001

35. Muñoz N, Bosch FX, de Sanjos,é S, Herrero R, Castellsagu,é X, Shah $\mathrm{KV}$, et al. Epidemiologic classification of human papillomavirus types associated with cervical cancer. $N$ Engl J Med. (2003) 348:518-27. doi: 10.1056/NEJMoa021641

36. Tjalma WAA, Fiander A, Reich O, Powell N, Nowakowski AM, Kirschner B, Koiss R, et al. Differences in human papillomavirus type distribution in high-grade cervical intraepithelial neoplasia and invasive cervical cancer in Europe. Int J Cancer (2013) 132:854-67. doi: 10.1002/ijc.27713.

37. Stein AP, Saha S, Yu M, Kimple RJ, Lambert PF. Prevalence of human papillomavirus in oropharyngeal squamous cell carcinoma in the United States across time. Chem Res Toxicol. (2014) 27:462-9. doi: $10.1021 /$ tx $500034 \mathrm{c}$

38. Gillison ML, Chaturvedi AK, Anderson WF, Fakhry C. Epidemiology of human papillomavirus-positive head and neck squamous cell carcinoma. $J$ Clin Oncol. (2015) 29:3235-42. doi: 10.1200/JCO.2015.61.6995

39. Gillison ML, Castellsagué X, Chaturvedi A, Goodman MT, Snijders P, Tommasino M, et al. Eurogin Roadmap: comparative epidemiology of HPV infection and associated cancers of the head and neck and cervix. Int J Cancer (2014) 134:497-507. doi: 10.1002/ijc.28201
40. Centers for disease control and prevention I. (CDC) Human papillomavirusassociated cancers - United States, 2004-2008. MMWR Morb Mortal Wkly. Rep. (2012) 61:258-261.

41. Cutts F, Franceschi S, Goldie S, Castellsague X, de Sanjose S, Garnett G, et al. Human papillomavirus and HPV vaccines: a review. Bull. WHO (2007) 85:719-26. doi: 10.2471/BLT.06.038414

42. Apter D, Wheeler CM, Paavonen J, Castellsague X, Garland SM, Skinner SR, et al. Efficacy of human papillomavirus 16 and 18 (HPV-16/18) AS04-adjuvanted vaccine against cervical infection and precancer in young women: final event-driven analysis of the randomized, double-blind PATRICIA trial. HPV PATRICIA Study Group Clin Vaccine Immunol. (2015) 22:361-73. doi: 10.1128/CVI.00591-14

43. Lehtinen M, Apter D, Baussano I, Eriksson T, Natunen K, Paavonen $\mathrm{J}$, et al. Characteristics of a cluster-randomized phase IV human papillomavirus vaccination effectiveness trial. Vaccine (2015) 33:1284-90. doi: $10.1016 / j . v a c c i n e .2014 .12 .019$

44. Luckett R, Feldman S. Impact of 2, 4 and 9-valent HPV vaccines on morbidity and mortality from cervical cancer. Hum Vaccin Immunother. (2016) 12:1332-42. doi: 10.1080/21645515.2015.1108500

45. Romanowski B, Schwarz TF, Ferguson L, Peters K, Dionne M, Behre U, et al. Sustained immunogenicity of the HPV-16/18 AS04-adjuvanted vaccine administered as a two-dose schedule in adolescent girls: five-year clinical data and modeling predictions from a randomized study. Hum Vaccin Immunother. (2016) 12:20-9. doi: 10.1080/21645515.2015.1065363

46. Skinner SR, Apter D, Carvalho ND, Harper DM, Konno R, Paavonen J, et al. Human papillomavirus (HPV)-16/18 AS04-adjuvanted vaccine for the prevention of cervical cancer and HPV-related diseases. Expert Rev Vaccines (2016) 15:367-87. doi: 10.1586/14760584.2016.1124763

47. Wheeler CM, Skinner SR, Rosario-Raymundo MRD, Garland SM, Chatterjee A, Lazcano-Ponce E, et al. Efficacy, safety, and immunogenicity of the human papillomavirus 16/18 AS04-adjuvanted vaccine in women older than 25 years: 7-year follow-up of the phase 3, double-blind, randomized controlled VIVIANE study. Lancet Infect Dis. (2016) 16:115468. doi: 10.1016/S1473-3099(16)30120-7

48. Willame C, Rosillon D, Zima J, Angelo M-G, Stuurman AL, Vroling $\mathrm{H}$, et al. Risk of new onset autoimmune disease in 9- to 25-year-old women exposed to human papillomavirus-16/18 AS04-adjuvanted vaccine in the United Kingdom. Hum Vaccin Immunother. (2016) 12:2862-71. doi: 10.1080/21645515.2016.1199308

49. Tezal M. Interaction between chronic inflammation and oral HPV infection in the etiology of head and neck cancers. Int J Otolaryngol. (2012) 2012:575242. doi: 10.1155/2012/575242

50. Bal-Yilmaz H, Koniak-Griffin D. Knowledge, behaviors, and attitudes about human papilloma virus among nursing students in izmir, Turkey. J. Cancer Educ. (2017) 33:814-820. doi: 10.1007/s13187-017-1163-1

51. Kim JJ, Burger EA, Sy S, Campos NG. Optimal cervical cancer screening in women vaccinated against human papillomavirus. J Natl Cancer Inst. (2017) 109:djw216. doi: 10.1093/jnci/djw216

52. Presser BE, Katz ML, Shoben AB, Moore D, Ruffin MT, Paskett ED, et al. Effects of an education intervention about HPV self-testing for healthcare providers and staff. J Cancer Educ. (2017) doi: 10.1007/s13187017-1164-0. [Epub ahead of print].

53. Khallouf $\mathrm{H}$, Grabowska AK, Riemer AB. Therapeutic vaccine strategies against human papillomavirus. Vaccine (2014) 2:422-62. doi: $10.3390 /$ vaccines 2020422

54. Panatto D, Amicizia D, Bragazzi NL, Rizzitelli E, Tramalloni D, Valle I, et al. Chapter eight-human papillomavirus vaccine: state of the art and future perspectives. Adv Protein Chem Struct Biol. (2015) 101:231-322. doi: 10.1016/bs.apcsb.2015.08.004

55. Yang $\mathrm{A}$, Jeang J, Cheng $\mathrm{K}$, Cheng $\mathrm{T}$, Yang $\mathrm{B}$, Wu TC, et al. Current state in the development of candidate therapeutic HPV vaccines. Expert Rev Vaccines (2016) 15:989-1007. doi: 10.1586/14760584.2016. 1157477

56. Lehtinen $M$, Paavonem J. Vaccination against human papilloma viruses shows great promise. Lancet (2004) 364:1731-2. doi: 10.1016/S01406736(04)17410-2

57. Gonçalves AK, Cobucci RN, Rodrigues HM, de Melo AG, Giraldo PC. Safety, tolerability and side effects of human papillomavirus vaccines: 
a systematic quantitative review. Braz J Infect Dis. (2014) 18:651-9. doi: 10.1016/j.bjid.2014.02.005

58. Chatterjee S, Chattopadhyay A, Samanta L, Panigrahi P. HPV and cervical cancer epidemiology- Current status of HPV vaccination in India. Asian Pac J Cancer Prev. (2016) 17:3663-73.

59. Yang A, Farmer E, Lin J, Wu TC, Hung CF. The current state of therapeutic and T-cell based vaccines against human papilloma viruses. Virus Res. (2017) 231:148-65. doi: 10.1016/j.virusres.2016.12.002

60. Pouyanfard S, Müller M. Human papilloma virus first and second generation vaccines- current status and future directions. Biol Chem. (2017) 398:871-89. doi: 10.1515/hsz-2017-0105

61. Hallez S, Simon P, Maudoux F, Doyen J, Noël JC, Beliard A, et al. Phase I/II trial of immunogenicity of a human papillomavirus (HPV) type 16 E7 protein-based vaccine in women with oncogenic HPV-positive cervical intraepithelial neoplasia. Cancer Immunol Immunother. (2004) 53:642-50. doi: 10.1007/s00262-004-0501-4

62. Palefsky JM, Berry JM, Jay N, Krogstad M, Da Costa M, Darragh TM, et al. A trial of SGN-00101 (HspE7) to treat high-grade anal intraepithelial neoplasia in HIV-positive individuals. AIDS (2006) 20, 1151-5.

63. Roman LD, Wilczynski S, Muderspach LI, Burnett AF, O'meara A, Brinkman JA, et al. A phase II study of Hsp-7 (SGN-00101) in women with highgrade cervical intraepithelial neoplasia. Gynecol Oncol. (2007) 106:558-66. doi: 10.1016/j.ygyno.2007.05.038

64. Einstein MH, Kadish AS, Burk RD, Kim MY, Wadler S, Streicher H, et al. Heat shock fusion protein-based immunotherapy for treatment of cervical intraepithelial neoplasia III. Gynecol Oncol. (2007) 106:453-60. doi: 10.1016/j.ygyno.2007.04.038

65. Carifi M, Napolitano D, Morandi M, Dall'Olio D. Recurrent respiratory papillomatosis: current and future perspectives. Ther. Clin. RiskManag. (2015) 11:731-8. doi: 10.2147/TCRM.S81825

66. Kawana K, Adachi K, Kojima S, Kozuma S, Fujii T. Therapeutic human papillomavirus (HPV) vaccines: a novel approach. Open Virol J. (2012) 6:264-9. doi: 10.2174/1874357901206010264

67. Esquerré M, Momot M, Goubier A, Misseri Y, Bissery MC. Bivalent adenylate cyclase (CYA)-based therapeutic vaccines: eradication of tumor cells expressing different antigens over time. Cancer Res. (2015) 75(15 Supplement), 2507-07. doi: 10.1158/1538-7445.AM2015-2507

68. Riedmann EM. Two therapeutic HPV vaccine candidates successful in phase 1. Hum Vaccin Immunother. (2012) 8:1741-1. doi: 10.4161/hv.23373

69. Liu TY, Hussein WM, Toth I, Skwarczynski M. Advances in peptide-based human papillomavirus therapeutic vaccines. Curr Top Med Chem. (2012) 12:1-12. doi: 10.2174/156802612802652402

70. de Vos van Steenwijk PJ, Ramwadhdoebe TH, Löwik MJ, van der Minne CE, Berends-van der Meer DM, Fathers LM, et al. A placebo-controlled randomized HPV16 synthetic long-peptide vaccination study in women with high-grade cervical squamous intraepithelial lesions. Cancer Immunol Immunotherapy (2012) 61:1485-92. doi: 10.1007/s00262-012-1292-7

71. Kenter GG, Welters MJ, Valentijn AR, Lowik MJ, Berends-van der Meer DM, Vloon AP, et al. Vaccination against HPV-16 oncoproteins for vulvar intraepithelial neoplasia. N.Engl.J. Med. (2009) 361:1838-47. doi: 10.1056/NEJMoa0810097

72. van Poelgeest MI, Welters MJ, van Esch EM, Stynenbosch LFM, Kerpershoek G, van Persijn van Meerten EL, et al. HPV16 synthetic long peptide (HPV16SLP) vaccination therapy of patients with advanced or recurrent HPV16induced gynecological carcinoma, a phase II trial. J. Transl.Med. (2013) 11:88. doi: 10.1186/1479-5876-11-88

73. Solares AM, Baladron I, Ramos T, Valenzuela C, Borbon Z, Fanjull S, et al. Safety and immunogenicity of a human papillomavirus peptide vaccine (CIGB-228) in women with high-grade cervical intraepithelial neoplasia: first-in-human, proof-of-concept trial. ISRN Obstet. Gynecol. (2011) 2011:292951. doi: 10.5402/2011/292951

74. Nezafat N, Ghasemi Y, Javadi G, Khoshnoud MJ, Omidinia E. A novel multiepitope peptide vaccine against cancer: an in silico approach. J Theor Biol. (2014) 349:121-134. doi: 10.1016/j.jtbi.2014.01.018

75. Barrios K, Celis E. TriVax-HPV: an improved peptide-based therapeutic vaccination strategy against human papillomavirus-induced cancers. Cancer Immunol Immunother. (2012) 61:1307-1317. doi: 10.1007/ s00262-012-1259-8
76. Soria-Guerra RE, Nieto-Gomez R, Govea-Alonso DO, RosalesMendoza S. An overview of bioinformatics tools for epitope prediction: implications on vaccine development. J Biomed Inform. (2015) 53:405-14. doi: 10.1016/j.jbi.2014.11.003

77. Dhanda SK, Usmani SS, Agrawal P, Nagpal G, Gautam A, Raghava GP. Novel in silico tools for designing peptide-based subunit vaccines and immunotherapeutics. Brief Bioinform. (2016) 18:467-78. doi: 10.1093/bib/bbw025

78. Jackwood MW, Hickle L, Kapil S, Silva R. Vaccine development using recombinant DNA technology. Council Agric Sci Technol. (2008) 38:1-11.

79. Backert L, Kohlbacher O. Immunoinformatics and epitope prediction in the age of genomic medicine. Genome Med. (2015) 7:119. doi: 10.1186/s13073-015-0245-0

80. He Y, Xiang Z. Databases and in silico tools for vaccine design. In: Kortagere S, editor. In Silico Models for Drug Discovery. Methods in Molecular Biology (Methods and Protocols), Vol. 993. Totowa, NJ: Humana Press (2013). p. 115-27. doi: 10.1007/978-1-62703-342-8_8

81. Kumar A, Hussain S, Sharma G, Mehrotra R, Gissmann L, Das BC, et al. Identification and validation of immunogenic potential of India specific HPV-16 variant constructs: in-silicoandin-vivo insight to vaccine development. Sci Rep. (2015) 5:15751. doi: 10.1038/srep15751

82. Kaushik S, Shrivastav VK, Shrivastav A, Jana AM. In silico vaccine design against the target L1 binding protein of human papillomavirus, an etiological agent of cervical cancer, using bioinformatics tools. Int J Pharm Sci Res. (2013) 42:4758-62. doi: 10.13040/IJPSR.0975-8232.4(10).4758-62

83. Yao Y, Huang W, Yang X, Sun W, Liu X, Cun W, et al. HPV-16 E6 and E7 protein $\mathrm{T}$ cell epitopes prediction analysis based on distributions of HLA-A loci across populations: an in silico approach. Vaccine (2013) 31:2289-2294. doi: 10.1016/j.vaccine.2013.02.065

84. de Oliveira LMF, Morale MG, Chaves AAM, Cavalher AM, Lopes AS, de Oliveira Diniz M, et al. Design, immune responses and anti-tumor potential of an HPV16 E6E7 multi-epitope vaccine. PLoS ONE (2015) 10:e0138686. doi: 10.1371 /journal.pone. 0138686

85. Keskin DB, Reinhold B, Lee SY, Zhang G, Lank S, O'Connor D, et al. (2011). Direct identification of an HPV-16 tumor antigen from cervical cancer biopsy specimens. Front Immunol. 13:75. doi: 10.3389/fimmu.2011.00075

86. Baidya S, Das R, Kabir MG, Arifuzzaman M. Epitope design of L1 protein for vaccine production against Human Papilloma Virus types 16 and 18. Bioinformation (2017) 13:86-93. doi: 10.6026/97320630013086

87. Kuck D, Lau T, Leuchs B, Kern A, Müller M, Gissmann L, et al. Intranasal vaccination with recombinant adeno-associated virus type 5 against human papillomavirus type 16 L1. J Virol. (2006) 80:2621-30. doi: 10.1128/JVI.80.6.2621-2630.2006

88. Nieto K, Salvetti A. AAV vector vaccines against infectious diseases. Front Immunol. (2014) 5:5. doi: 10.3389/fimmu.2014.00005

89. Nieto K, Stahl-Hennig C, Leuchs B, Müller M, Gissmann L, Kleinschmidt JA. Intranasal vaccination with AAV5 and 9 vectors against human papillomavirus type 16 in rhesus macaques. Hum. Gene Ther. (2012) 23:73341. doi: 10.1089/hum.2011.202

90. Wieking BG, Vermeer DW, Spanos WC, Lee KM, Vermeer, P, Lee WT, et al. A non-oncogenic HPV 16 E6/E7 vaccine enhances treatment of HPV expressing tumors. Cancer Gene Ther. (2012) 19:667-74. doi: $10.1038 /$ cgt.2012.55

91. Zuniga A, Wang Z, Liniger M, Hangartner L, Caballero M, Pavlovic J, et al. Attenuated measles virus as a vaccine vector. Vaccine (2007) 25:2974-83. doi: 10.1016/j.vaccine.2007.01.064

92. Cantarella G, Liniger M, Zuniga A, Schiller JT, Billeter M, Naim $\mathrm{HY}$, et al. Recombinant measles virus-HPV vaccine candidates for prevention of cervical carcinoma. Vaccine (2009) 27:3385-90. doi: $10.1016 /$ j.vaccine.2009.01.061

93. Gupta G, Giannino V, Rishi N, Glueck R. Immunogenicity of next-generation HPV vaccines in non-human primates: measles-vectored HPV vaccine versus Pichia pastoris recombinant protein vaccine. Vaccine (2016) 34:472431. doi: 10.1016/j.vaccine.2016.07.051

94. Mendiretta SK, Glueck R, Giannino V, Cantarella G, Scuderi F, Billeter M, et al. Combined measles-human papilloma vaccine. US 9623098 B2 (2017).

95. Graham VV, Sutter G, Jos,é MV, García-Carranca A, Erfle V, Mendoza $\mathrm{NM}$, et al. Human tumor growth is inhibited by a vaccinia virus carrying 
the E2 gene of bovine papillomavirus. Cancer (2000) 88:1650-62. doi: 10 . 1002/(SICI)1097-0142(20000401)88:7<1650::AID-CNCR20>3.0.CO;2-L

96. Garcia-Hernandez E, Gonzalez-Sanchez JL, Andrade-Manzano A, Contreras ML, Padilla S, Guzman CC, et al. Regression of papilloma high-grade lesions (CIN 2 and CIN 3) is stimulated by therapeutic vaccination with MVA E2 recombinant vaccine. Cancer Gene Ther. (2006) 13:592-7. doi: 10.1038/sj.cgt.7700937

97. Nayereh KG, Khadem G. Preventive and therapeutic vaccines against human papillomaviruses associated cervical cancers. Iran J Basic Med Sci. (2012) 15:585-601.

98. Corona Gutierrez CM, Tinoco A, Navarro T, Contreras ML, Cortes RR, Calzado P, et al. (2004). Therapeutic vaccination with MVA E2 can eliminate precancerous lesions (CIN 1, CIN 2, and CIN 3) associated with infection by oncogenic human papillomavirus. Hum Gene Ther. 15:421-31. doi: $10.1089 / 10430340460745757$

99. Albarran AC, de la Garza A, Quiroz, BJCC, Zea EV, Estrada ID, Fuentez EM, et al. MVA E2 recombinant vaccine in the treatment of human papillomavirus infection in men presenting intraurethral flat condyloma: a phase I/II study. Bio. Drugs (2007) 21:47-60. doi: 10.2165/00063030-200721010-00006

100. Adams M, Borysiewicz L, Fiander A, Man S, Jasani B, Navabi H, et al. Clinical studies of human papilloma vaccines in pre-invasive and invasive cancer. Vaccine (2001) 19:2549-56. doi: 10.1016/S0264-410X(00) 00488-6

101. Kaufmann AM, Stern PL, Rankin EM, Sommer H, Nuessler V, Schneider A, et al. Safety and immunogenicity of TA-HPV, a recombinant vaccinia virus expressing modified human papillomavirus (HPV)-16 and HPV-18 E6 and E7 genes, in women with progressive cervical cancer. Clin Cancer Res. (2002) 8:3676-85.

102. Baldwin PJ, van der Burg SH, Boswell CM, Offringa R, Hickling JK, Dobson $\mathrm{J}$, et al. Vaccinia-expressed human papillomavirus 16 and 18 e6 and e7 as a therapeutic vaccination for vulval and vaginal intraepithelial neoplasia. Clin Cancer Res. (2003) 9:5205-13.

103. Davidson EJ, Faulkner RL, Sehr P, Pawlita M, Smyth LJ, Burt DJ, et al. Effect of TA-CIN (HPV 16 L2E6E7) booster immunization in vulval intraepithelial neoplasia patients previously vaccinated with TA-HPV (vaccinia virus encoding HPV 16/18 E6E7). Vaccine (2004) 22:2722-9. doi: 10.1016/j.vaccine.2004.01.049

104. Rosales C, Graham VV, Rosas GA, Merchant H, Rosales R. A recombinant vaccinia virus containing the papilloma E2 protein promotes tumor regression by stimulating macrophage antibodydependent cytotoxicity. Cancer Immunol Immunother. (2000) 49:347-60. doi: 10.1007/s002620000125

105. Rosales R, Lopez-Contreras M, Rosales C, Magallanes-Molina JR, GonzalezVergara R, Arroyo-Cazarez JM, et al. Regression of human papillomavirus intraepithelial lesions is induced by MVA E2 therapeutic vaccine. HumGene Ther. (2014) 25:1035-49. doi: 10.1089/hum.2014.024

106. Brun JL, Dalstein V, Leveque J, Mathevet P, Raulic P, Baldauf JJ, et al. Regression of high-grade cervical intraepithelial neoplasia with TG4001 targeted immunotherapy. Am J Obstetr Gynecol. (2011) 204:169e161-168. doi: 10.1016/j.ajog.2010.09.020

107. Maciag PC, Radulovic S, Rothman J. The first clinical use of a live-attenuated Listeria monocytogenes vaccine: a phase I safety study of Lm-LLO-E7 in patients with advanced carcinoma of the cervix. Vaccine (2009) 27:3975-83. doi: 10.1016/j.vaccine.2009.04.041

108. Gunn GR, Zubair A, Peters C, Pan ZK, Wu TC, Paterson Y. Two Listeria monocytogenes vaccine vectors that express different molecular forms of human papilloma virus-16 (HPV-16) E7 induce qualitatively different $\mathrm{T}$ cell immunity that correlates with their ability to induce regression of established tumors immortalized by HPV-16. J Immunol. (2001) 167:6471-9. doi: 10.4049/jimmunol.167.11.6471

109. Cory L, Chu C. ADXS-HPV: a therapeutic Listeria vaccination targeting cervical cancers expressing the HPV E7 antigen. Hum. Vaccin. Immunother. (2014) 10:3190-5. doi: 10.4161/hv.34378

110. Peng S, Ji H, Trimble C, He L, Tsai YC, Yeatermeyer J, et al. (2004). Development of a DNA vaccine targeting human papillomavirus type 16 oncoprotein E6. J Virol. 78:8468-76. doi: 10.1128/JVI.78.16.84688476.2004
111. Morris V, Eng C. Summary of emerging targets in anal cancer: the case for an immunotherapy based-approach. J Gastrointest Cancer. (2016) 7:721. doi: 10.21037 /jgo.2016.08.03

112. Kawana K, Adachi K, Kojima S, Taguchi A, Tomio K, Yamashita A, et al. (2014). Oral vaccination against HPV E7 for treatment of cervical intraepithelial neoplasia grade 3 (CIN3) elicits E7-specific mucosal immunity in the cervix of CIN3 patients. Vaccine 32:6233-9. doi: 10.1016/j.vaccine.2014.09.020

113. Lee SJ, Yang $\mathrm{A}, \mathrm{Wu} \mathrm{TC}$, Hung CF. Immunotherapy for human papillomavirus-associated disease and cervical cancer: review of clinical and translational research. Gynecol Oncol. (2016) 27:e51. doi: 10.3802/jgo.2016.27.e51

114. Sasagawa T, Tani M, Basha W, Rose RC, Tohda H, Giga-Hama Y, et al. A human papillomavirus type 16 vaccine by oral delivery of L1 protein. Virus Res. (2005) 110:81-90. doi: 10.1016/j.virusres.2005. 02.001

115. Kirnbauer R, Booy F, Cheng N, Lowy DR, Schiller JT. Papillomavirus L1 major capsid protein self-assembles into virus-like particles that are highly immunogenic. Proc Natl Acad Sci. USA. (1992) 89:12180-84. doi: 10.1073/pnas.89.24.12180

116. Bazan SB, de Alencar Muniz Chaves A, Aires KA, Cianciarullo AM, Garcea RL, Ho PL. Expression and characterization of HPV-16 L1 capsid protein in Pichia pastoris. Arch Virol. (2009) 154:1609-17. doi: 10.1007/s00705-009-0484-8

117. Wang JW, Roden RB. Virus-like particles for the prevention of human papillomavirus-associated malignancies. Expert Rev Vaccine. (2013) 12:12941. doi: $10.1586 /$ erv. 12.151

118. Stanley M. HPV - immune response to infection and vaccination. Infect Agent Cancer. (2010) 5:19. doi: 10.1186/1750-9378-5-19

119. Dochez C, Bogers JJ, Verhelst R, Rees H. HPV vaccines to prevent cervical cancer and genital warts: an update. Vaccine (2014) 32:1595-601. doi: 10.1016/j.vaccine.2013.10.081

120. Harper DM, Demars LR. Primary strategies for HPV infection and cervical cancer prevention. Clin Obstet Gynecol. (2014) 57:256-78. doi: 10.1097/GRF.0000000000000027

121. Zhou J, Sun XY, Stenzel DJ, Frazer IH. Expression of vaccinia recombinant HPV $16 \mathrm{~L} 1$ and L2 ORF proteins in epithelial cells is sufficient for assembly of HPV virion-like particles. Virology (1991) 185:251-7.

122. Jagu S, Karanam B, Gambhira R, Chivukula SV, Chaganti RJ, Lowy DR, et al. Concatenated multitype L2 fusion proteins as candidate prophylactic pan-human papillomavirus vaccines. J Natl Cancer Inst. (2009) 101:782-92. doi: 10.1093/jnci/djp106

123. Villa LL, Ault KA, Giuliano AR, Costa RL, Petta CA, Andrade RP, et al. Immunologic responses following administration of a vaccine targeting human papillomavirus types 6, 11, 16, and 18. Vaccine (2006) 24:5571-83. doi: 10.1016/j.vaccine.2006.04.068

124. Villa LL, Costa RL, Petta CA, Andrade RP, Paavonen J, Iversen OE, et al. High sustained efficacy of a prophylactic quadrivalent human papillomavirus types 6/11/16/18 L1 virus-like particle vaccine through 5 years of follow-up. $\mathrm{Br} \mathrm{J}$ Cancer (2006) 95:1459-66. doi: 10.1038/sj.bjc.6603469

125. Fraillery D, Baud D, Pang SYY, Schiller J, Bobst M, Zosso N, et al. Salmonella enterica serovar Typhi Ty21a expressing human papillomavirus type $16 \mathrm{~L} 1$ as a potential live vaccine against cervical cancer and typhoid fever. Clin Vaccine Immunol. (2007) 14:1285-95. doi: 10.1128/CVI.001 64-07

126. Li W, Liu H, Yang X, Zheng J, Wang Y, Si L. Development of prophylactic recombinant HPV58-attenuated Shigella live vector vaccine and evaluation of its protective efficacy and immunogenicity in the guinea pig keratoconjunctivitis model. Acta Biochim Biophys Sin. (2009) 41:137-45. doi: 10.1093/abbs/gmn016

127. Yan X, Wang D, Liang F, Fu L, Guo C. HPV16L1-attenuated Shigella recombinant vaccine induced strong vaginal and systemic immune responses in guinea pig model. Hum Vaccin Immunother. (2014) 10:3491-8. doi: $10.4161 / \mathrm{hv} .36084$

128. Cortes-Perez NG, Kharrat P, Langella $P$, Bermúdez-Humarán LG. Heterologous production of human papillomavirus type-16 L1 protein by a lactic acid bacterium. BMC Res Notes (2009) 2:1. doi: 10.1186/1756-0500-2-167 
129. Abdoli A, Soleimanjahi H, Fotouhi F, Pour Beiranvand S, Kianmehr Z. Human papillomavirus type16-L1 VLP production in insect cells. Iran J Basic Med Sci. (2013) 16:891-5.

130. Senger T, Schädlich L, Gissmann L, Müller M. Enhanced papillomaviruslike particle production in insect cells. Virology (2009) 388:344-53. doi: 10.1016/j.virol.2009.04.004

131. Hofmann KJ, Cook JC, Joyce JG, Brown DR, Schultz LD, George HA, et al. Sequence determination of human papillomavirus type 6a and assembly of virus-like particles in Saccharomyces cerevisiae. Virology (1995) 209:506-18. doi: 10.1006/viro.1995.1283

132. Rose RC, White WI, Li M, Suzich JA, Lane C, Garcea RL. Human papillomavirus type 11 recombinant L1 capsomeres induce virus-neutralizing antibodies. J Virol. (1998) 72:6151-4.

133. Kjaer SK, Sigurdsson K, Iversen OE, Hernandez-Avila M, Wheeler CM, Perez G, et al. A pooled analysis of continued prophylactic efficacy of quadrivalent human papillomavirus (types 6/11/16/18) vaccine against highgrade cervical and external genital lesions. Cancer Prev Res (Phila.) (2009) 2:868-78. doi: 10.1158/1940-6207.CAPR-09-0031

134. Mello CF. Vaccination against human papillomavirus. Einstein (Sau Paulo) (2013) 11:547-9. doi: 10.1590/S1679-45082013000400027

135. Cook JC, Joyce JG, George HA, Schultz LD, Hurni WM, Jansen KU, et al. Purification of virus-like particles of recombinant human papillomavirus type 11 major capsid protein L1 from Saccharomyces cerevisiae. Protein Expr Purif. (1999) 17:477-84.

136. Kwag HL, Kim HJ, Chang DY, Kim HJ. The production and immunogenicity of human papillomavirus type 58 virus-like particles produced in Saccharomyces cerevisiae. J Microbiol. (2012) 50:813-20. doi: 10.1007/s12275-012-2292-1

137. Hu Y, Huang SJ, Chu K, Wu T, Wang ZZ, Yang CL, et al. Safety of an Escherichia coli-expressed bivalent human papillomavirus (types 16 and 18) L1 virus-like particle vaccine: an open-label phase I clinical trial. Hum Vaccin Immunother. (2014) 10:469-75. doi: 10.4161/hv.26846

138. Xu D, Wang D, Yang X, Cao M, Yu J, Wang Y. Fusion of HPV L1 into Shigella surface IcsA: a new approach in developing live attenuated Shigella-HPV vaccine. Antivir Res. (2014) 102:61-9. doi: 10.1016/j.antiviral.2013.12.003

139. Xu Y, Wang Q, Han Y, Song G, Xu X. Type-specific and cross-reactive antibodies induced by human papillomavirus $31 \mathrm{~L} 1 / \mathrm{L} 2$ virus-like particles. J Med. Microbiol. (2007) 56:907-13. doi: 10.1099/jmm.0.47073-0

140. Pineo CB, Hitzeroth II, Rybicki EP. Immunogenic assessment of plantproduced human papillomavirus type $16 \mathrm{~L} 1 / \mathrm{L} 2$ chimaeras. Plant Biotechnol J. (2013) 11:964-75. doi: 10.1111/pbi.12089

141. Tumban E, Peabody J, Peabody DS, Chackerian B. A universal virus-like particle-based vaccine for human papillomavirus: longevity of protection and role of endogenous and exogenous adjuvants. Vaccine (2013) 31:464754. doi: 10.1016/j.vaccine.2013.07.052

142. Jiang RT, Schellenbacher C, Chackerian B, Roden RB. Progress and prospects for L2-based human papillomavirus vaccines. Expert Rev. Vaccines (2016) 15:853-62. doi: 10.1586/14760584.2016.1157479

143. Tyler M, Tumban E, Chackerian B. Second-generation prophylactic HPV vaccines: successes and challenges. Expert Rev Vaccine. (2014) 13:247-55. doi: $10.1586 / 14760584.2014 .865523$

144. Boxus M, Fochesato M, Miseur A, Mertens E, Dendouga N, Brendle S, et al. Broad cross protection is induced by a human papillomavirus vaccine composed of L1/L2 chimeric virus-like particles in preclinical models. J Virol. (2016) 90:6314-25. doi: 10.1128/JVI.00449-16

145. Schädlich L, Senger T, Gerlach B, Mücke N, Klein C, Bravo IG, et al. Analysis of modified human papillomavirus type $16 \mathrm{~L} 1$ capsomeres: the ability to assemble into larger particles correlates with higher immunogenicity. $J$ Virol. (2009) 83:7690-705. doi: 10.1128/JVI.02588-08

146. Hassan SW, Waheed MT, Müller M, Clarke JL, Shinwari ZK, Lössl AG. Expression of HPV-16 L1 capsomeres with glutathione-S-transferase as a fusion protein in tobacco plastids: an approach for a capsomerebased HPV vaccine. Hum Vaccin Immunother. (2014) 10:2975-82. doi: $10.4161 / 21645515.2014 .970973$

147. Schellenbacher C, Roden RBS, Kirnbauer R. Developments in L2-based human papilloma virus (HPV) vaccines. Virus Res. (2017) 231:166-75. doi: 10.1016/j.virusres.2016.11.020
148. Cordeiro MN, Paolini F, Massa S, Curzio G, Illiano E, Duarte Silva AJ, et al. Anti-tumor effects of genetic vaccines against HPV major oncogenes. Hum Vaccin Immunother. (2015) 11:45-52. doi: 10.4161/hv.34303

149. Schiller JT, Lowy DR. Raising expectations for subunit vaccine. J Infect Dis. (2015) 211:1373-5. doi: 10.1093/infdis/jiu648

150. Donnelly JJ, Ulmer JB, Shiver JW, Liu MA. DNA vaccines. Annu Rev Immunol. (1997) 15:617-48. doi: 10.1146/annurev.immunol.15.1.617

151. Gurunathan S, Klinman DM, Seder RA. DNA vaccines: immunology, application, and optimization. Annu Rev Immunol. (2000) 18:927-74. doi: 10.1146/annurev.immunol.18.1.927

152. Dhama K, Mahendran M, Gupta PK, Rai A. DNA vaccines and their applications in veterinary practice: Current perspectives. Vet Res Commun. (2008) 32:341-56. doi: 10.1007/s11259-008-9040-3

153. Hung CF, Monie A, Alvarez RD, Wu TC. DNA vaccines for cervical cancer: from bench to bed side. Exp Mol Med. (2007) 39:679-89. doi: $10.1038 / \mathrm{emm} .2007 .74$

154. Alvarez-Salas LM. Amolimogene bepiplasmid, a DNA-based therapeutic encoding the E6 and E7 epitopes from HPV, for cervical and anal dysplasia. Curr Opin Mol Ther. (2008) 10:622-8.

155. Trimble CL, Frazer IH. Development of therapeutic HPV vaccines. Lancet Oncol. (2009) 10:975-80. doi: 10.1016/S1470-2045(09)70227-X

156. Fazeli M, Soleimanjahi H, Dadashzadeh S. Further stimulation of cellular immune responses through association of HPV-16 E6, E7 and L1 genes in order to produce more effective therapeutic DNA vaccines in cervical cancer model. Iran J Cancer Prev. (2015) 8:18.

157. Bahrami AA, Ghaemi A, Tabarraei A, Sajadian A, Gorji A, Soleimanjahi H. DNA vaccine encoding HPV-16 E7 with mutation in LYCYE pRb-binding motif induces potent anti-tumor responses in mice. J Virol Methods (2014) 206:12-8. doi: 10.1016/j.jviromet.2014.05.013

158. Villarreal DO, Wise MC, Siefert RJ, Yan J, Wood LM, Weiner DB. Ubiquitin-like molecule ISG15 acts as an immune adjuvant to enhance antigen-specific CD8 T-cell tumor immunity. Mol Ther. (2015) 23:1653-62. doi: $10.1038 / \mathrm{mt} .2015 .120$

159. Van Damme P, Bouillette-Marussig M, Hens A, De Coster I, Depuydt C, Goubier A, et al. GTL001, A therapeutic vaccine for women infected with human papillomavirus 16 or 18 and normal cervical cytology: results of a phase I clinical trial. Clin Cancer Res. (2016) 22:3238-48. doi: 10.1158/1078-0432.CCR-16-0085

160. Zong J, Wang C, Wang Q, Peng Q, Xu Y, Xie X, et al. HSP70 and modified HPV 16 E7 fusion gene without the addition of a signal peptide gene sequence as a candidate therapeutic tumor vaccine. Oncol Rep. (2013) 30:3020-6. doi: 10.3892/or.2013.2742

161. Bloy N, Buqué A, Aranda F, Castoldi F, Eggermont A, Cremer I, et al. Trial watch: naked and vectored DNA-based anticancer vaccines. Oncoimmunology (2015) 4:e1026531. doi: 10.1080/2162402X.2015.1026531

162. Bagarazzi ML, Yan J, Morrow MP, Shen X, Parker RL, Lee JC, et al. Immunotherapy against HPV16/18 generates potent TH1 and cytotoxic cellular immune responses. Sci Transl Med. (2012) 4:155ra138. doi: $10.1126 /$ scitranslmed.3004414

163. Trimble CL, Morrow MP, Kraynyak KA, Shen X, Dallas M, Yan J, et al. Safety, efficacy, and immunogenicity of VGX-3100, a therapeutic synthetic DNA vaccine targeting human papillomavirus 16 and 18 E6 and E7 proteins for cervical intraepithelial neoplasia 2/3: a randomised, double-blind, placebo-controlled phase $2 b$ trial. Lancet (2015) 386:2078-88. doi: 10.1016/S0140-6736(15)00239-1

164. Senovilla L, Vacchelli E, Garcia P, Eggermont A, Fridman WH, Galon J, et al. Trial watch: DNA vaccines for cancer therapy. Oncoimmunology (2013) 2:e23803. doi: 10.4161/onci.23803

165. Fioretti D, Iurescia S, Rinaldi M. Recent advances in design of immunogenic and effective naked DNA vaccines against cancer. Recent Pat. Anticancer Drug Discov. (2014) 9:66-82. doi: 10.2174/1574891X113089990037

166. Pol J, Bloy N, Obrist F, Eggermont A, Galon J, Herve Fridman W, et al. Trial watch: DNA vaccines for cancer therapy. Oncoimmunology (2014) 3:e28185. doi: 10.4161/onci.28185

167. Colluru VT, Johnson LE, Olson BM, McNeel DG. Preclinical and clinical development of DNA vaccines for prostate cancer. Urol Oncol. (2016) 34:193-204. doi: 10.1016/j.urolonc.2013.09.014 
168. Dhama K, Wani MY, Deb R, Karthik K, Tiwari R, Barathidasan R, et al. Plant based oral vaccines for human and animal pathogens - a new era of prophylaxis: current and future perspectives. J Exp Biol Agri Sci. (2013) 1:1-12.

169. Ko K. Expression of recombinant vaccines and antibodies in plants. Monoclon Antib Immunodiag Immunother. (2014) 33:192-8. doi: 10.1089/mab.2014.0049

170. Bagchi S. Red-algae derivative could be useful adjunct to HPV vaccine. Lancet Oncol. (2006) 7:623. doi: 10.1016/S1470-2045(06)70781-1

171. Demurtas OC, Massa S, Ferrante P, Venuti A, Franconi R, Giuliano G. A Chlamydomonas-derived Human Papillomavirus 16 E7 vaccine induces specific tumor protection. PLoS ONE (2013) 8:e61473. doi: 10.1371/journal.pone.0061473

172. Liu HL, LI WS, Lei T, Zheng J, Zhang Z, YAN XF, et al. Expression of human papillomavirus type $16 \mathrm{~L} 1$ protein in transgenic tobacco plants. Acta Biochim Biophys Sin. (2005) 37:153-8. doi: 10.1093/abbs/37.3.153

173. Varsani A, Williamson AL, Rose RC, Jaffer M, Rybicki EP. Expression of Human papillomavirus type 16 major capsid protein in transgenic Nicotiana tabacum cv. Xanthi. Arch Virol. (2003) 148:1771-86. doi: 10.1007/s00705-003-0119-4

174. Kohl TO, Hitzeroth II, Christensen ND, Rybicki EP. Expression of HPV-11 L1 protein in transgenic Arabidopsis thaliana and Nicotiana tabacum. BMC Biotechnol. (2007) 7:56. doi: 10.1186/1472-6750-7-56

175. Cerovska N, Hoffmeisterova H, Moravec T, Plchova H, Folwarczna J, Synkova $\mathrm{H}$, et al. Transient expression of Human papillomavirus type 16 L2 epitope fused to $\mathrm{N}$-and C-terminus of coat protein of Potato virus $\mathrm{X}$ in plants. J Biosci. (2012) 37:125-33. doi: 10.1007/s12038-0119177-z

176. Millán FS, Ortigosa SM, Hervás-Stubbs S, Corral-Martínez P, SeguíSimarro JM, Gaétan J, et al. Human papillomavirus L1 protein expressed in tobacco chloroplasts self-assembles into virus-like particles that are highly immunogenic. Plant Biotechnol J. (2008) 6:427-41. doi: 10.1111/j.1467-7652.2008.00338.x

177. Lamprecht RL, Kennedy P, Huddy SM, Bethke S, Hendrikse M, Hitzeroth II, et al. Production of Human papillomavirus pseudovirions in plants and their use in pseudovirion-based neutralisation assays in mammalian cells. Sci Rep. (2016) 6:20431. doi: 10.1038/srep20431

178. Venuti A, Massa S, Mett V, Vedova LD, Paolini F, Franconi R, et al. An E7based therapeutic vaccine protects mice against HPV16 associated cancer. Vaccine (2009) 27:3395-7. doi: 10.1016/j.vaccine.2009.01.068

179. Waheed MT, Thones N, Muller M, Hassan SW, Gottschamel J, Lossl $\mathrm{E}$, et al. Plastid expression of a double-pentameric vaccine candidate containing human papillomavirus-16 L1 antigen fused with LTB as adjuvant: transplastomic plants show pleiotropic phenotypes. Plant Biotechnol J. (2011) 9, 651-660. doi: 10.1111/j.1467-7652.2011.00612.x

180. Rybicki EP. Plant-based vaccine against viruses. Virol. J. (2014) 11:205. doi: 10.1186/s12985-014-0205-0

181. Rahma OE, Herrin VE, Ibrahim RA, Toubaji A, Bernstein S, Dakheel O, et al. Pre-immature dendritic cells (PIDC) pulsed with HPV16 E6 or E7 peptide are capable of eliciting specific immune response in patients with advanced cervical cancer. J Transl Med. (2014) 12:353. doi: 10.1186/s12967-0140353-4

182. Zhou ZX, Li D, Guan SS, Zhao C, Li ZL, Zeng Y. Immunotherapeutic effects of dendritic cells pulsed with a codon-optimized HPV 16 E6 and E7 fusion gene in vivo and in vitro. Asian Pac. J Cancer Prev. (2014) 16:3843-3847. doi: 10.7314/APJCP.2015.16.9.3843

183. Zhu Y, Zheng Y, Mei L, Liu M, Li S, Xiao H, et al. Enhanced immunotherapeutic effect of modified HPV16 E7-pulsed dendritic cell vaccine by an adeno-shRNA-SOCS1 virus. Int J Oncol. (2013) 43:1151-9. doi: 10.3892/ijo.2013.2027

184. Santin AD, Bellone S, Palmieri M, Zanolini A, Ravaggi A, Siegel ER, et al. Human papillomavirus type 16 and 18 E7-pulsed dendritic cell vaccination of stage IB or IIA cervical cancer patients: a phase I escalating-dose trial. $J$ Virol. (2008) 82:1968-79. doi: 10.1128/JVI.02343-07

185. Ramanathan P, Ganeshrajah S, Raghanvan RK, Singh SS, Thangarajan R. Development and clinical evaluation of dendritic cell vaccines for HPV related cervical cancer-a feasibility study. Asian Pac J Cancer Prev. (2014) 15:5909-16. doi: 10.7314/APJCP.2014.15.14.5909
186. Wheeler CM, Castellsagué X, Garland SM, Szarewski A, Paavonen J, Lehtinen M. et al. Cross-protective efficacy of HPV-16/18 AS04adjuvanted vaccine against cervical infection and precancer caused by non-vaccine oncogenic HPV types: 4-year end-of-study analysis of the randomised, double-blind PATRICIA trial. Lancet Oncol. (2012) 13:100-110. doi: 10.1016/S1470-2045(11)70287-X

187. Monk BJ, Tewari KS. Evidence-based therapy for recurrent cervical cancer. $J$ Clin Oncol. (2014) 32:2687-90. doi: 10.1200/JCO.2014.56.8733

188. Tjalma WAA. There are two prophylactic human papillomavirus vaccines against cancer, and they are different. J Clin Oncol. (2015) 33:964-65. doi: 10.1200/JCO.2014.59.0331

189. Chao C, Klein NP, Velicer CM, Sy LS, Slezak JM, Takhar H, et al. Surveillance of autoimmune conditions following routine use of quadrivalent human papillomavirus vaccine. J Intern Med. (2012) 271:193-203. doi: 10.1111/j.1365-2796.2011.02467.x

190. Baker B, Guimarães LE, Tomljenovic L, Agmon-Levin N, Shoenfeld Y. The safety of human papilloma virus-blockers and the risk of triggering autoimmune diseases. Expert Opin Drug Saf. (2015) 14, 1387-1394. doi: 10.1517/14740338.2015.1073710

191. Brown D, Kulkarni AS, Pillsbury M, Luxembourg A, Saah A. Clarification on the impact of cervarix vaccination on human papillomavirus infection and cervical cancer in the United Kingdom. Hum Vaccin Immunother. (2016) 12:1940-2. doi: 10.1080/21645515.2016.1143159

192. Buchanan TR, Graybill WS, Pierce JY. Morbidity and mortality of vulvar and vaginal cancers: impact of 2-, 4-, and 9-valent HPV vaccines. Hum Vaccin Immunother. (2016) 12:1352-6. doi: 10.1080/21645515.2016.11 47634

193. Villa LL, Costa RL, Petta CA, Andrade RP, Ault KA, Giuliano AR, et al. Prophylactic quadrivalent human papillomavirus (types 6, 11, 16, and 18) L1 virus-like particle vaccine in young women: a randomized double-blind placebo-controlled multicenter phase II efficacy trial. Lancet Oncol. (2005) 6:271-8. doi: 10.1016/S1470-2045(05)70101-7

194. Future I/II Study Group. Four year efficacy of prophylactic human papillomavirus quadrivalent vaccine against low grade cervical, vulvar, and vaginal intraepithelial neoplasia and anogenital warts: randomized controlled trial. BMJ (2010) 341:c3493. doi: 10.1136/bmj. c3493

195. Nygård M, Saah A, Munk C, Tryggvadottir L, Enerly E, Hortlund M, et al. Evaluation of the long-term anti-human papillomavirus 6 (HPV6), 11, 16, and 18 immune responses generated by the quadrivalent $\mathrm{HPV}$ vaccine. Clin Vaccine Immunol. (2015) 22:943-8. doi: 10.1128/CVI.00133-15

196. Centers for Disease Control and Prevention (CDC). FDA licensure of bivalent human papillomavirus vaccine (HPV2, Cervarix) for use in females and updated HPV vaccination recommendations from the Advisory Committee on Immunization Practices (ACIP). Morb Mortal Wkly Rep. (2010) 59:626.

197. Monie A, Hung CF, Roden R, Wu TC. Cervarix ${ }^{\mathrm{TM}}$ : a vaccine for the prevention of HPV 16, 18-associated cervical cancer. Biol Targets Ther. (2008) 2:107-13.

198. Schiller JT, Castellsagué X, Garland SM. A review of clinical trials of human papillomavirus prophylactic vaccines. Vaccine. (2012) 30:F123-38. doi: 10.1016/j.vaccine.2012.04.108

199. Gillison ML, Chaturvedi AK, Lowy DR. HPV prophylactic vaccines and the potential prevention of noncervical cancers in both men and women. Cancer (2008) 113:3036-46. doi: 10.1002/cncr.23764

200. de Sanjose S, Quint WG, Alemany L, Geraets DT, Klaustermeier JE, Lloveras $\mathrm{B}$, et al. Human papillomavirus genotype attribution in invasive cervical cancer: a retrospective cross-sectional worldwide study. Lancet Oncol. (2010) 11:1048-56. doi: 10.1016/S1470-2045(10)70230-8

201. Van den Bergh JMJ, Guerti K, Willemen Y, Lion E, Cools N, Goossens H, et al. HPV vaccine stimulates cytotoxic activity of killer dendritic cells and natural killer cells against HPV-positive tumor cells. J Cell Mol Med. (2014) 18:1372-80. doi: 10.1111/jcmm.12284

202. Harper DM, Franco EL, Wheeler C, Ferris DG, Jenkins D, Schuind A, et al. Efficacy of a bivalent L1 virus-like particle vaccine in prevention of infection with human papillomavirus types 16 and 18 in young women: a randomized controlled trial. Lancet (2004) 364:1757-65. doi: 10.1016/S0140-6736(04)17398-4 
203. Paavonen J, Jenkins D, Bosch FX, Naud P, Salmerón J, Wheeler $\mathrm{CM}$, et al. Efficacy of a prophylactic adjuvanted bivalent L1 viruslike-particle vaccine against infection with human papillomavirus types 16 and 18 in young women: an interim analysis of a phase III double-blind, randomized controlled trial. Lancet (2007) 369:2161-70. doi: 10.1016/S0140-6736(07)60946-5

204. Giannini SL, Hanon E, Moris P, Van Mechelen M, Morel S, Dessy F, et al. Enhanced humoral and memory B cellular immunity using HPV16/ 18 L1 VLP vaccine formulated with the MPL/aluminium salt combination (AS04) compared to aluminium salt only. Vaccine (2006) 24:5937-49. doi: 10.1016/j.vaccine.2006.06.005

205. Naud PS, Roteli-Martins CM, De Carvalho NS, Teixeira JC, de Borba PC, Sanchez N, et al. Sustained efficacy, immunogenicity, and safety of the HPV-16/18 AS04-adjuvanted vaccine: final analysis of a long-term followup study up to 9.4 years post-vaccination. Hum Vaccin Immunother. (2014) 10:2147-62. doi: 10.4161/hv.29532

206. Schwarz T, Spaczynski M, Kaufmann A, Wysocki J, Gałaj A, Schulze $\mathrm{K}$, et al. Persistence of immune responses to the HPV-16/18 AS04adjuvanted vaccine in women aged $15-55$ years and first-time modelling of antibody responses in mature women: results from an open-label 6year follow-up study. BJOG (2015) 122:107-18. doi: 10.1111/1471-0528. 13070

207. Effelterre TPV, Hogea C, Taylor SM. Projected impact of Cervarix ${ }^{\mathrm{TM}}$ vaccination on oncogenic human papillomavirus infection and cervical cancer in the United Kingdom. Hum Vaccin Immunother. (2016) 12:8-19. doi: 10.1080/21645515.2015.1054584

208. Petrosky E, Bocchini Jr JA, Hariri S, Chesson H, Curtis CR, Saraiya M, et al. Use of 9-valent human papillomavirus (HPV) vaccine: updated HPV vaccination recommendations of the advisory committee on immunization practices. MMWR Morb Mortal Wkly Rep. (2015) 64:300-4.

209. De Vincenzo R, Conte C, Ricci C, Scambia G, Capelli G. Long-term efficacy and safety of human papillomavirus vaccination. Int J Womens Health (2014) 6:999. doi: 10.2147/IJWH.S50365

210. Luxembourg A, Kjaer SK, Nygard M, Ellison MC, Marshall JB, Radley D, et al. Design of a long-term follow-up effectiveness, immunogenicity and safety study of women who received the 9-valent human papillomavirus vaccine. Contemp. Clin. Trials (2017) 52:54-61. doi: 10.1016/j.cct.2016.10.006

211. Moreira ED, Block SL, Ferris D, Giuliano AR, Iversen OE, Joura EA, et al. Safety profile of the 9-valent HPV vaccine: a combined analysis of 7 phase III clinical trials. Pediatrics. (2016) 138:e20154387. doi: 10.1542/peds.2015-4387

212. Santarelli GD, Derkay CS. HPV vaccines for treatment and prevention of recurrent respiratory papillomatosis. Curr Otorhinolaryngol Rep. (2016) 4:85-9. doi: 10.1007/s40136-016-0119-z

213. Largeron N, Petry KU, Jacob J, Bianic F, Anger D, Uhart M. An estimate of the public health impact and cost-effectiveness of universal vaccination with a 9-valent HPV vaccine in Germany. Expert Rev Pharmacoecon Outcomes Res. (2016) 17:85-98. doi: 10.1080/14737167.2016.1208087

214. Zhai L, Tumban E. Gardasil-9: A global survey of projected efficacy. Antivir Res. (2016) 130:101-9. doi: 10.1016/j.antiviral.2016.03.016

215. McKeage K, Lyseng-Williamson KA. 9-Valent human papillomavirus recombinant vaccine (Gardasil $($ 9): a guide to its use in the EU. Drugs Ther Perspect. (2016) 32:414-21. doi: 10.1007/s40267-016-0337-y

216. Pink J, Parker B, Petrou S. Cost effectiveness of HPV vaccination: asystematic review of modelling approaches. Pharmaco Economics (2016) 34:847-61. doi: 10.1007/s40273-016-0407-y

217. Esquerré M, Bouillette-Marussig M, Goubier A, Momot M, Gonindard C, Keller H, et al. GTL001, a bivalent therapeutic vaccine against human papillomavirus 16 and 18, induces antigen-specific $\mathrm{CD} 8^{+} \mathrm{T}$ cell responses leading to tumor regression. PLoS ONE (2017) 12:e0174038. doi: 10.1371/journal.pone.0174038

218. Preville X, Ladant D, Timmerman B, Leclerc C. Eradication of established tumors by vaccination with recombinant Bordetella pertussis adenylate cyclase carrying the human papillomavirus 16 E7 oncoprotein. Cancer Res. (2005) 65:641-9.

219. Berraondo P, Nouze C, Preville X, Ladant D, Leclerc C. Eradication of large tumors in mice by a tritherapy targeting the innate, adaptive, and regulatory components of the immune system. Cancer Res. (2007) 67:884755. doi: 10.1158/0008-5472.CAN-07-0321

220. Yang DY, Bracken K. Update of the new 9-valent vaccine for human papilloma virus prevention. Can Fam Physician. (2016) 62:399-402.

221. Van Damme P, Olsson SE, Block S, Castellsague X, Gray GE, Herrera T, et al. Immunogenicity and safety of a 9-valent HPV vaccine. Pediatrics (2015) 136:e28-e39. doi: 10.1542/peds.2014-3745

222. Vesikari T, Brodszki N, van Damme P, Diez-Domingo J, Icardi G, Petersen LK, et al. (2015). A randomized, double-blind, phase III study of the immunogenicity and safety of a 9-valent human papillomavirus L1 virus-

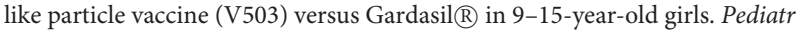
Infect Dis. J. 34, 992-998. doi: 10.1097/INF.0000000000000773

223. Castellsagu,é X, Giuliano AR, Goldstone S, Guevara A, Mogensen O, Palefsky $\mathrm{JM}$, et al.. Immunogenicity and safety of the 9-valent HPV vaccine in men. Vaccine (2015) 33:6892-901. doi: 10.1016/j.vaccine.2015.06.088

224. van'tKlooster TM, Kemmeren JM, van der Maas NAT, and de Melker HE. Reported adverse events in girls aged 13-16 years after vaccination with the human papillomavirus (HPV)-16/18 vaccine in Netherlands. Vaccine (2011) 29:4601-7. doi: 10.1016/j.vaccine.2011.04.050

225. Luna J, Plata M, Gonzales A, Maldonado I, Nossa C, Radley D, et al. Long-term foll ow-up observation of the safety, immunogenicity, and effectiveness of GardasilTM in adult women. PLoS ONE (2013) 8:e83431. doi: 10.1371/journal.pone.0083431

226. Garland SM, Chuengg TK, McNeil S, Petersen LK, Romaguera J, VazquezNarvaez J, et al. Safety and immunogenicity of 19 -valent HV vaccine in females 12-26 years of age who previously received the quadrivalent HPV vaccine. Vaccine (2015) 30:6855-64. doi: 10.1016/j.vaccine.2015.08.059

227. Giuliano A, Isaac-Soriano K, Torres AN, Abrahamsen M, Ingles DJ, Sirak BA, et al. Immunogenicity and safety of Gardasil among midadult aged men (27-45 years(-the MAM study. Vaccine (2015) 33:5640-6. doi: $10.1016 /$ j.vaccine.2015.08.072

228. Liu XC, Bell CA, Simmonds KA, Svensen LW, Russel ML. Adverse events following HPV vaccination, Alberta 2006-2014. Vaccine (2016) 34:1800-5. doi: 10.1016/j.vaccine.2016.02.040

229. Van Damme P, Meijer CJLM, Kieninger D, Schuyleman A, Thomas S, Luxembourg A, et al. A phase-III clinical study to compare the immunogenicity and safety of the 9-valent and quadrivalent $\mathrm{HPV}$ vaccines in men. Vaccine (2016) 34:4205-12. doi: 10.1016/j.vaccine.2016.06.056

230. Bonde U, Jorgensen JS, Lamont RF, Mogensen O. Is HPV vaccination in pregnancy safe? Hum Vacc Immunotherapeut. (2016) 12:1960-4. doi: $10.1080 / 21645515.2016 .1160178$

231. Grimaldi-Bensouda L, Rossignol M, Koné-Paut I, Krivitzky A, LebrunFrenay C, Clet J, et al. Risk of autoimmune diseases and human papillomavirus (HPV) vaccines: six years of case-referent surveillance. $J$ Autoimmun. (2017) 79:84-90. doi: 10.1016/j.jaut.2017.01.005

232. Miranda S, Chaignot C, Collin C, Dray-Spira R, Weill A. Huamn papillomavirus vaccination and risk of autoimmune diseases: a large cohort study of over 2 million young girls in France. Vaccine (2017) 35:4761-8. doi: 10.1016/j.vaccine.2017.06.030

233. Mouchet J, Salvo F, Raschi E, Poluzzi E, Antonazzo IC, De Ponti F, et al. Human papillomavirus vaccine and demyelinating diseases-A systematic review and meta-analysis. Pharmacol Res. (2018) 132:108-18. doi: 10.1016/j.phrs.2018.04.007

234. Ruiz-Sternberg AM, Moreira EDJr, Restrepo JA, Lazcano-Ponce E, Carbello R, Silva A, et al. Efficacy, immunogenicity and safety of a 9-valent human papillomavirus vaccine in Latin American girls, boys, and young women. Papillomavirus Res. (2018) 5:63-74. doi: 10.1016/j.pvr.2017. 12.004

235. Andrews N, Stowe J, Miller E. No increased risk of Guillain-Barre syndrome after human papillomavirus vaccine: a sefl-controlled case-series study in England. Vaccine (2017) 35:1729-32. doi: 10.1016/j.vaccine.2017.01.076

236. Schäffer V, Wimmer S, Rotaru I, Topakian R, Haring HP, Aichner FT. HPV vaccine: a cornerstone of female health - a possible cause of ADEM? J Neurol. (2008) 255:1818-20. doi: 10.1007/s00415-008-0867-x

237. Sutton I, Lahoria R. Clouston P, Barnett MH. CNS demyelination and quadrivalent HPV vaccination Multiple. Sclerosis (2009) 15:116-9. doi: $10.1177 / 1352458508096868$ 
238. Dimario FJ, Haijar M, Ciesielski T. A 16-year-old girl with bilateral visual loss and left hemiparesis following an immunization against human papilloma virus. J Child Neurol. (2010) 25:321-7. doi: 10.1177/0883073809349322

239. Karussis D, Petrou P. The spectrum of post-vaccination inflammatory CNS demyelinating syndrome. Autoimmun Rev. (2014) 13:215-24. doi: 10.1016/j.autrev.2013.10.003

240. Sekiguchi K, Yasui N, Kowa H, Kanda F, Toda T. Two cases of acute disseminated encephalomyelitis following vaccination against human papilloma virus. Intern Med. (2016) 55:3181-4. doi: 10.2169/internalmedicine.55.5472

241. Chang H, Lee HL, Yeo M, Kim JS, Shin DI, Lee SS, et al. Recurrent optic neuritis and neuromyelitis optica-IgG following first and second human papillomavirus vaccinations. Clin Neurol Neurosurg (2016) 144:1268. doi: 10.1016/j.clineuro.2016.03.023

242. Geier DA, Geier MR. Quadrivalent human papillomavirus vaccine and autoimmune adverse events: a case-control assessment of the vaccine adverse event reporting system (VAERS) database. Immunol Rev. (2017) 65:46-54. doi: 10.1007/s12026-016-8815-9

243. Melief CJ. Treatment of established lesions caused by high-risk human papilloma virus using a synthetic vaccine. J Immunother. (2012) 35:215-6. doi: 10.1097/CJI.0b013e318248f17f

244. Conesa-Zamora P. Immune responses against virus and tumor in cervical carcinogenesis: treatment strategies for avoiding the HPV-induced immune escape. Gynecol Oncol. (2013) 131:480-8. doi: 10.1016/j.ygyno.2013.08.025

245. Singh S, Aggarwal BB. Activation of transcription factor NF-kappa B is suppressed by curcumin (diferuloylmethane). J Biol Chem. (1995) 270:24995-5000. doi: 10.1074/jbc.270.42.24995

246. Aggarwal BB, Kumar A, Bharti AC. Anticancer potential of curcumin: preclinical and clinical studies. Anticancer Res. (2003) 23:363-98.

247. Divya CS, Pillai MR. Antitumor action of curcumin in human papillomavirus associated cells involves downregulation of viral oncogenes, prevention of NF-кB and AP-1 translocation, and modulation of apoptosis. Mol Carcinog. (2006) 45:320-32. doi: 10.1002/mc.20170

248. Mishra A, Kumar R, Tyagi A, Kohaar I, Hedau S, Bharti AC, et al. Curcumin modulates cellular AP-1, NF- $\mathrm{B}$, and HPV16 E6 proteins in oral cancer. Ecancermedicalscience (2015) 9:525. doi: 10.3332/ecancer.2015.525

249. Banister CE, Liu C, Pirisi L, Creek KE, Buckhaults PJ. Identification and characterization of HPV-independent cervical cancers. Oncotarget. (2017) 8:13375-86. doi: 10.18632/oncotarget.14533

250. Tseng CW, Trimble C, Zeng Q, Monie A, Alvarez RD, Huh WK, et al. Low-dose radiation enhances therapeutic HPV DNA vaccination in tumor-bearing hosts. Cancer Immunol Immunother. (2009) 58:737-48. doi: 10.1007/s00262-008-0596-0

251. Cao Y, Zhao J, Yang Z, Cai Z, Zhang B, Zhou Y, et al. CD4+FOXP3+ regulatory $\mathrm{T}$ cell depletion by low-dose cyclophosphamide prevents recurrence in patients with large condylomata acuminata after laser therapy. Clin Immunol. (2010) 136:21-9. doi: 10.1016/j.clim.2010.02.020

252. Rosenberg SA. Cell transfer immunotherapy for metastatic solid cancerwhat clinicians need to know. Nat Rev Clin Oncol. (2011) 8:577-85. doi: 10.1038/nrclinonc.2011.116

253. Haas AR, Sun J, Vachani A, Wallace AF, Silverberg M, Kapoor V, et al. Cycloxygenase-2 inhibition augments the efficacy of a cancer vaccine. Clin Cancer Res. (2006) 12:214-22. doi: 10.1158/1078-0432.CCR-05-1178

254. Kim S, Buchlis G, Fridlender ZG, Sun J, Kapoor V, Cheng G, et al. Systemic blockade of transforming growth factor-beta signaling augments the efficacy of immunogene therapy. Cancer Res. (2008) 68:10247-56. doi: 10.1158/0008-5472.CAN-08-1494

255. Castano AP, Mroz P, Hamblin MR. Photodynamic therapy and anti-tumour immunity. Nat Rev Cancer (2006) 6:535-45. doi: 10.1038/nrc1894

256. Brackett CM, Gollnick SO. Photodynamic therapy enhancement of anti-tumor immunity. Photochem Photobiol Sci. (2011) 10:649-52. doi: $10.1039 / \mathrm{c0pp} 00354 \mathrm{a}$

257. Korbelik M. Cancer vaccines generated by photodynamic therapy. Photochem Photobiol Sci. (2011) 10:664-9. doi: 10.1039/c0pp00343c

258. Stern PL, van der Burg SH, Hampson IN, Broker T, Fiander A, Lacey CJ, et al. Therapy of human papillomavirus-related disease. Vaccine (2012) 30:F71-82. doi: 10.1016/j.vaccine.2012.05.091
259. Fu Y, Bao Y, Hui Y, Gao X, Yang M, Chang J. Topical photodynamic therapy with 5-aminolevulinic acid for cervical high-risk HPV infection. Photodiag Photodyn Ther. (2016) 13:29-33. doi: 10.1016/j.pdpdt.2015.12.004

260. Wang HW, Zhang LL, Miao F, Lv T, Wang XL, Huang Z. Treatment of HPV infection-associated cervical condylomata acuminata with 5-aminolevulinic acid-mediated photodynamic therapy. Photochem Photobiol. (2012) 88:5659. doi: 10.1111/j.1751-1097.2011.01060.x

261. Kines R, Çuburu N, Kobayashi H, MacDougall J, Pinos EDL, Schiller J. HPV based photodynamic therapy: a new approach for anti-cancer therapy (VAC12P.1019). J Immunol. (2014) 192 (1 Suppl.):206.8.

262. Soergel P, Dahl GF, Onsrud M, Hillemanns P. Photodynamic therapy for cervical intraepithelial neoplasia 1-3 and human papillomavirus (HPV) infection with methylaminolevulinate and hexaminolevulinate adouble-blind, dose-finding study. Lasers Surg Med. (2012) 44:468-74. doi: $10.1002 / 1 \mathrm{sm} .22041$

263. Hillemanns P, Einstein $\mathrm{MH}$, Iversen OE. Topical hexaminolevulinate photodynamic therapy for the treatment of persistent human papilloma virus infections and cervical intraepithelial neoplasia. Expert Opin Investig Drugs (2015) 24:273-281. doi: 10.1517/13543784.2015.990150

264. Lee RG, Vecchiotti MA, Heaphy J, Panneerselvam A, Schluchter $\mathrm{MD}$, Oleinick NL, et al. Photodynamic therapy of cottontail rabbit papillomavirus-induced papillomas in a severe combined immunodeficient mouse xenograft system. Laryngoscope. (2010) 120:618-24. doi: 10.1002/lary.20709

265. Rosa LP, da Silva FC. Antimicrobial photodynamic therapy: anew therapeutic option to combat infections. J Med Microb Diagn. (2014) 3:158. doi: 10.4172/2161-0703.1000158

266. Sauvaget C, Muwonge R, Sankaranarayanan R. Meta-analysis of the effectiveness of cryotehrapy in the treatment of cervical intraepithelial neoplasia. Int J Gynaecol Obstet. (2013) 120:218-23. doi: 10.1016/j.ijgo.2012.10.014

267. Wright Jr TC, Kuhn L. Alternative approaches to cervical cancer screening for developing countries. Best Pract Res Clin Obstet Gynaecol. (2012) 26:197208. doi: 10.1016/j.bpobgyn.2011.11.004

268. Mutombo AB, Tozin R, Simoens C, Lisbeth R, Bogers J, Van Geertruyden $\mathrm{J}-\mathrm{P}$, et al. Efficacy of antiviral drug AV2 in the treatment of human papilloma virus-associated precancerous lesions of the uterine cervix: arandomized placebo-controlled clinical trial in Kinshasa, DR Congo. (KINVAV study) Contemp Clin Trials Commun. (2017) 8:135-9. doi: 10.1016/j.conctc.2017.09.008

269. Katundu K, Bateman AC, Pfaendler KS, Mwanahamuntu MH, Kapambwe $\mathrm{S}$, Vermund $\mathrm{SH}$, et al. The effect of cryotherapy on human papilloma virus clearance among HIV-positive women in Lusaka, Zambia. J Low Genit Tract Dis. (2015) 19:301-6. doi: 10.1097/LGT.00000000000 00131

270. Greenfield I, Cuthill S. Antivirals. In: Human Papillomaviruses. Clinical and Scientific Advances. Sterling JC, Tyring SK editors. London: Arnold Publisher (2001). pp. 120-130.

271. Krebs HB, Helmkamp BF. Chronic ulcerations following topical therapy with 5-fluorouracil for vaginal human papillomavirus-associated lesions. Obstet Gynecol. (1991) 78:205-208.

272. Um SJ, Lee SY, Kim EJ, Myoung J, Namkoong SE, Park JS. Downregulation of human papillomavirus E6/E7 oncogene by arsenic trioxide in cervical carcinoma cells. Cancer Lett. (2002) 181:11-22. doi: 10.1016/S0304-3835(02)00039-3

273. Singh S, Bhat MK. Carboplatin induces apoptotic cell death through downregulation of constitutively active nuclear factorkappaB in human HPV-18 E6-positive HEp-2 cells. Biochem Biophys Res Commun. (2004) 318:346-53. doi: 10.1016/j.bbrc.2004. 04.037

274. Chen FP. Efficacy of imiquimod 5\% cream for persistent human papillomavirus in genital intraepithelial neoplasm. Taiwan J Obstet Gynecol. (2013) 52:475-8. doi: 10.1016/j.tjog.2013.10.004

275. Svahn KS, Göransson U, Chryssanthou E, Olsen Sjölin J, Strömstedt AA. (2014). Induction of gliotoxin secretion in Aspergillus fumigatus by bacteria-associated molecules. PLoS ONE 9:e93685. doi: 10.1371/journal.pone.0093685 
276. Nguyen VT, Lee JS, Qian ZJ, Li YX, Kim KN, Heo SJ, et al. Gliotoxin isolated from marine fungus Aspergillus sp. induces apoptosis of human cervical cancer and chondrosarcoma cells. Mar Drugs (2013) 12:69-87. doi: $10.3390 / \mathrm{md} 12010069$

277. Clamp PJ, Saunders MW. Systematic review of intralesional cidofovir dosing regimens in the treatment of recurrent respiratory papillomatosis. Int $J$ Pediatr Otorhinolaryngol. (2013) 77:323-8. doi: 10.1016/j.ijporl.2012.12.027

278. Derkay CS, Volsky PG, Rosen CA, Pransky SM, McMurray JS, Chadha $\mathrm{NK}$, et al. Current use of intralesional cidofovir for recurrent respiratory papillomatosis. Laryngoscope (2013) 123:705-12. doi: 10.1002/lary.23673

279. Mlynarczyk-Bonikowska B, Majewska A, Malejczyk M, Mlynarczyk G, Majewski S. Antiviral medication in sexually transmitted diseases. Part I: HSV, HPV. Mini Rev. Med. Chem. (2013) 13:1837-45.

280. Ksiazek J, Prager JD, Sun GH, Wood RE, Arjmand EM. Inhaled cidofovir as an adjuvant therapy for recurrent respiratory papillomatosis. Otolaryngol Head Neck Surg. (2011) 144:639-41. doi: 10.1177/01945998103 95353

281. Amine A, Rivera S, Opolon P, Dekkal M, Biard DS, Bouamar H, et al. Novel anti-metastatic action of cidofovir mediated by inhibition of E6/E7, CXCR4 and Rho/ROCK signaling in HPV tumor cells. PLoS ONE (2009) 4:e5018. doi: 10.1371/journal.pone.0005018

282. Martinez GFV, Perez E, Perez A, Suarez E. A Randomized Double-Blind Placebo-Controlled Trial of AV2-BOBE-1 in the Treatment of Cervical Dysplasia. Internal Confident Report. (2010).

283. Song XX, Liu YL, Hao QY. Xinfuning combined with Baofukang suppository for 53 cases with cervical high risk human papillomavirus infection. J Oncol. (2011) 17:825-7.

284. Yang J, Pu YG, Zeng ZM, Yu ZJ, Huang N, Deng QW. Interferon for the treatment of genital warts: a systematic review. BMC Infect Dis. (2009) 9:156. doi: 10.1186/1471-2334-9-156

285. Foldvari M, Kumar P. Recent progress in the application of nanotechnology for prevention and treatment of human papillomavirus infection. Ther Deliv. (2012) 3:1005-17. doi: 10.4155/tde.12.78

286. King M, Kumar P, Michel D, Batta R, Foldvari M. In vivo sustained der-mal delivery and pharmacokinetics of interferon alpha in biphasic vesicles after topical application. Eur J Pharm Biopharm. (2013) 84:532-9. doi: 10.1016/j.ejpb.2013.01.014

287. Song M, DiPaola RS, Cracchiolo BM, Gibbon DG, Hellmann M, NievesNeira W, et al. Phase 2 trial of paclitaxel, 13-cis retinoic acid, and interferon alfa-2b in the treatment of advanced stage or recurrent cervical cancer. Int J Gynecol Cancer. (2014) 24:1636-41. doi: 10.1097/IGC.00000000000 00258

288. Mosa C, Trizzino A, Trizzino A, Di Marco F, D’Angelo P, Farruggia P. Treatment of human papilloma virus infection with interferon alpha and ribavirin in a patient with acquired aplastic anemia. Int J Infect Dis. (2014) 23:25-27. doi: 10.1016/j.ijid.2013.11.021

289. Shrestha NK, Hamrock DJ. Successful treatment of disseminated human papillomavirus infection with pegylated interferon and ribavirin. Clin Infect Dis. (2010) 51:e4-e-6. doi: 10.1086/653428

290. Guo-Qin H. Clinical observation of paiteling on treatment of cervicitis combined with high-risk HPV infection. Chin J Woman Child Health Res. (2012) 23:675-7.

291. Buck CB, Thompson CD, Roberts JN, Muller M, Lowy DR, Schiller JT. Carrageenan is a potent inhibitor of papillomavirus infection. PLoS Pathog. (2006) 2:69. doi: 10.1371/journal.ppat.0020069

292. Novetsky AP, Keller MJ, Gradissimo A, Chen Z, Morgan SL, Xue X, et al. In vitro inhibition of human papillomavirus following use of a carrageenan-containing vaginal gel. Gynecol Oncol. (2016) 143:313-8. doi: 10.1016/j.ygyno.2016.09.003

293. Li J, Luo KZ, Lin Y, Chen WN, Lai SP. Laboratory study on anti-human papillomavirus activity of Bupleurum chinese. Chin J Dermato Venerol Integ Trad W Med. (2005) 4:171-3.

294. Xiao J, Wu J, Yu B. Therapeutic efficacy of Youdujing preparation in treating cervical high-risk papilloma virus infection patients. Zhongguo Zhong Xi Yi Jie He Za Zhi. (2012) 32:1212-5.

295. Wang SH, Zhang XS, Guan HS, Wang W. Potential anti-HPV and related cancer agents from marine resources: an overview. Mar Drugs (2014) 12:2019-35. doi: 10.3390/md12042019
296. Li GL, Xia Q, Chen SH, Gui SQ, Xu CJ. Effects of Pinellia extract fraction on expressions of HPVE6 and P53 genes in cervical cancer cell lines. China J Tradit Chin Med Pharm. (2012) 27:113-6.

297. Lin J, Chen L, Qiu X, Zhang N, Guo Q, Wang Y, et al. Traditional Chinese medicine for human papillomavirus (HPV) infections: a systematic review. Biosci Trends (2017) 11:267-73. doi: 10.5582/bst.2017. 01056

298. Ma XL, Xue XO, Li S, Wang Y, Xie W. Clinical study of Zibai gel on treatment of cervical high-risk human papillomavirus infection. Chin J Inform TCM. (2012) 19:9-12.

299. Hou MJ, Fan RQ, Sun J, Xuan GW, Chi FH. Effect of Chinese medicine Youdujing for human papilloma virus DNA. J Guangzhou Univ Tradit Chin Med. (1998) 15, 57-60.

300. Feng Y, Deng YH, Xuan GW, Zhou D, Sun J, Yuan XH, et al. Preparation and in vitro pharmacodynamics effect of the Youdujing cream. Chin Hosp Pharm J. (2004) 24:7-8.

301. Xiao J, Huang JL, Cai LE. Study of Youdujing in treating HR-HPV infected cervical lesions. Guangdong Med J. (2011) 32:2036-9.

302. Squiquera L, Taxman DJ, Brendle SA, Torres R, Sulley J, Hodge T, et al. Ranpirnase eradicates human papillomavirus in cultured cells and heals anogenital warts in a phase I study. Antivir Ther. (2017) 22:247-55. doi: 10.3851/IMP3133

303. Sulley J, Squiquera L. Topical composition containing ranpirnase. WO 2016028634 A1 (2016).

304. Saxena SK, Ardelt W. Methods of treating human papillomavirus. US 8663964 B2 (2014).

305. Putral LN, Bywater MJ, Gu W, Saunders NA, Gabrielli BG, Leggatt GR, et al. RNA interference against human papilloma virus oncogenes in cervical cancer cells results in increased sensitivity to cisplastin. Mol Pharmacol. (2005) 68:1311-9. doi: 10.1124/mol.105.014191

306. Singhania R, Khairuddin N, Clarke D, McMillan NA. RNA interference for the treatment of papillomavirus disease. Open Virol J. (2012) 6:204-15. doi: $10.2174 / 1874357901206010204$

307. Sima N, Wang W, Kong D, Deng D, Xu Q, Zhou J, et al. RNA interference against HPV16 E7 oncogene leads to viral E6 and E7 suppression in cervical cancer cells and apoptosis via upregulation of Rb and p53. Apoptosis (2008) 13:273-281. doi: 10.1007/s10495-007-0163-8

308. Yamato K, Yamada T, Kizaki M, Ui-Tei K, Natori Y, Fujino M, et al. New highly potent and specific E6 and E7 siRNAs for treatment of HPV16 positive cervical cancer. Cancer Gene Ther. (2008) 15:140-153. doi: 10.1038/sj.cgt.7701118

309. Zhou J, Peng C, Li B, Wang F, Zhou C, Hong D, et al. Transcriptional gene silencing of HPV16 E6/E7 induces growth inhibition via apoptosis in vitro and in vivo. Gynecol Oncol. (2012) 124:296-302. doi: 10.1016/j.ygyno.2011.10.028

310. Chang JT, Kuo TF, Chen YJ, Chiu CC, Lu YC, Li HF, et al. Highly potent and specific siRNAs against E6 or E7 genes of HPV16- or HPV18-infected cervical cancers. Cancer Gene Ther. (2010) 17:827-36. doi: $10.1038 /$ cgt.2010.38

311. Khairuddin N, Gantier MP, Blake SJ, Wu SY, Behlke MA, Williams BR, et al. siRNA-induced immunostimulation through TLR7 promotes antitumoral activity against HPV-driven tumors in vivo. Immunol. Cell Biol. (2012) 90:187-96. doi: 10.1038/icb.2011.19

312. Niu X-Y, Peng Z-L, Duan W-Q, Wang H Wang P. Inhibition of HPV 16 E6 oncogene expression by RNA interference in vitro and in vivo. Int J Gynecol. Cancer. (2006) 16:743-51. doi: 10.1111/j.1525-1438.2006.00384.x

313. Jung HS, Rajasekaran N, Ju W, Shin YK. Human papillomavirus: current and future RNAi therapeutic strategies for cervical cancer. J Clin Med. (2015) 4:1126-55. doi: $10.3390 / \mathrm{jcm} 4051126$

314. Burnett JC, Rossi JJ. RNA-based therapeutics: current progress and future prospects. Chem Biol. (2012) 19:60-71. doi: 10.1016/j.chembiol.2011.12.008

315. Novak N, Yu CF, Bieber T, Allam JP. Toll-like receptor 7 agonists and skin. Drug News Perspect. (2008) 21:158-65.

316. Archambault J, Melendy T. Targeting human papilloma virus genome replication for antiviral drug discovery. Antivir Ther. (2013) 18:271-83. doi: 10.3851/IMP2612

317. Terlou A, van Seters M, Kleinjan A, Heijmans-Antonissen C, Santegoets LA, Beckmann I, et al. Imiquimod-induced clearance of HPV is associated 
with normalization of immune cell counts in usual type vulvar intraepithelial neoplasia. Int J Cancer. (2010) 127:2831-40. doi: 10.1002/ijc.25302

318. Hoy SM. Polyphenon E 10\% ointment: in immunocompetent adults with external genital and perianal warts. Am J Clin Dermatol. (2012) 13:275-81. doi: 10.2165/11209370-000000000-00000

319. Guo Z, Wang X, Cheng D, Xia Z, Luan M, Zhang S. PD-1 blockade and OX40 triggering synergistically protects against tumor growth in a murine model of ovarian cancer. PLoS ONE (2014) 9: e89350. doi: 10.1371/journal.pone.0089350

320. Chu F, Cao J, Neelalpu SS. Versatile CAR T-cells for cancer immunotherapy. Contemp Oncol (Pozn) (2018) 22:73-80. doi: 10.5114/wo.2018.73892

321. Ben-Avi R, Farhi R, Ben-Nun A, Gorodner M, Greenberg E, Markel G, et al. Establishment of adoptive cell therapy with tumor infiltrating lymphocytes for non-small cell lung cancer patients. Cancer Immunol Immunother. (2018) 67:1221-30. doi: 10.1007/s00262-018-2174-4

322. Wang Y, Shang O, Xu W, Gu H, Wei L. Characterization of two new monoclonal antibodies agaisnst human papillomavirus type $16 \mathrm{~L} 1$ protein. Diag Pathol. (2014) 1:101. doi: 10.1186/1746-1596-9-101

323. Bhadauria P, Hockenberry K, Jiang Z, Christensen N, Dadachova E, Phaeton R. Serial monoclonal antibody administration demonstrates theraprutic effects via induction of apoptosis in HPV related cervical cancer. J Immunol. (2016) 196:214-9.

324. Kalogeropoulos CD, Moschos MM. Advances in diagnosis and treatment of HPV ocular surface infections. Med Hypothesis Discov Innov. Opthalmol. (2015) 4:31-5.

325. Burns RP, Wankum G, Giangiacomo J, Anderson PC. Dinitrochlorobenzene and debulking therapy of conjunctival papilloma. J Pedriatr Ophthalmol Strabismus (1983) 20:221-6.

326. Shields CL, Shields JA. Tumors of the conjunctiva and cornea. Surv. Ophthalmol. (2004) 49:3-24. doi: 10.1016/j.survophthal.2003.10.008

327. Pogorzelski M, Ting S, Gauler TC, Breitenbuecher F, Vossebein I, Hoffarth S. Impact of human papilloma virus infection on the response of head and neck cancers to anti-epidermal growth factor receptor antibody therapy. Cell Death Dis. (2014) 5:e1091. doi: 10.1038/cddis.2014.62

328. Piramal SA, Padigaru M, Agarwal VR, Deshpande GA. Compounds for the treatment of cancers associated with human papillomavirus. WO 2012176163 A2 (2012).

329. Rajendran SK, Paul P, Cheng YBF, Eklund P, Eriksson JE. Compounds for the treatment of HPV-induced carcinoma.WO 2016027005 A1 (2016).

330. Webb JR, Wick DA. Human papillomavirus E7 antigen compositions and uses thereof. US 20130209402 A1 (2013).

331. Colau BDA, Giannini S, Lockman L. Method of vaccination against human papilloma virus. WO $2013139744 \mathrm{Al}$ (2013).

332. Preville XEE, Leclerc C, Ladant D, Timmerman B. Recombinant protein carrying human papillomavirus epitopes inserted in an adenylate cyclase protein or fragment thereof therapeutic uses thereof. US 8637039 B2 (2014).

333. Neefe J, Goldstone S, Winnett M, Siegel M, Boux L. Human papilloma virus treatment. US 20080063661 A1 (2008).

334. Wu TC, Hung CF, Roden R. Methods of treatment of hpv related diseases. WO 2015021155 A1 (2015).

335. Quake SR, Wang J. Compositions and methods for cell targeted hpv treatment. WO $2016196282 \mathrm{Al}$ (2016).

336. Liu T, Meng S, Zhao L, Hong G. Use of New Type of anti-HPVpharmaceutical Preparation. EP 3072512 A1 (2016).

337. Roden R. Multitype hpv peptide compositions and methods for treatment or prevention of human papillomavirus infection. US 20100297144 A1 (2010).

338. Lide Y, Wensi Z, Qixiong X. Compound podophyllotoxin gel for treating HPV virus and preparation method thereof. CN 105287365 A (2016).

339. Neto MADFL, Caetano LC, Neto PADSP, Silva ZPD. Pharmaceutical composition using stryphnodendron extracts for treating HPV infections. US 9023405 B2 (2015).

340. Huang RCC. Abd-Elazem IS. Synergistic antiviral compositions comprising a viral attachment inhibitor, integration inhibitor, and proviral transcription inhibitor. US 9005889 B2 (2015).

341. Bertin W, Pecora T. Vaginal cream for the treatment of papilloma infection comprising docosanol, turmeric, amla and aloe. WO 2013171607 A1 (2013).

342. Hampson I, Hampson L. Treatment of cancer and benign proliferative disorders. WO $2015059485 \mathrm{~A} 1$ (2015).
343. Joyce JG, George HA, Hofman KJ, Jansen KU, Neeper MP. Recombinant human papillomavirus type 18 vaccine. US 5820870A (1998).

344. Alessa NAA. Composition for treatment and preventative of the human papilloma virus HPV infection, ulcerations and boils. CA 2967506 A1 (2016).

345. Clawson GA, Pa WH, Thiboutot D, Christensen N. Methods and materials for treating human papillomavirus infections. US 7704965 B2 (2010).

346. Buyuktimkin S, Buyuktimkin N, Yeager J. Topical treatment and prevention of human papilloma virus (HPV) infection. US $20050272700 \mathrm{~A} 1$ (2005).

347. Bashkin J, Edwards TG, Fisher C, Harris, GD Jr, Koeller KJ Jr. Guanidinylsubstituted polyamides useful for treating human papilloma virus. US 9133228 B2 (2015).

348. Zhang G, Shen Q, Lei J, Yuan J, Zhang M, Zhang Q, et al. Genes encoding major capsid protein L1 of human papilloma virus. WO 2009076824 A1 (2009).

349. Weiner DB, Yan J. Vaccines for human papilloma virus and methods for using the same. US 9050287 B2 (2015).

350. Apt D, Khavari P, Stemmer WPC. Human Papilloma Virus Vectors. US 6399383 B1 (2002).

351. Maldonado AE, Osorio PMO, Moreno VA, Martínez GLA, Melo PME, Enriquez MZI, et al. Effectiveness of photodynamic therapy in elimination of HPV-16 and HPV-18 associated with CIN I in Mexican women. Photochem Photobiol. (2017) 93:1269-75. doi: 10.1111/php.12769

352. Hu Z, Liu L, Zhang W, Liu H, Li J, Jiang L, et al. Dynamics of HPV viral loads reflect the treatment effect of photodynamic therapy in genital warts. Photodiagnosis Photodyn Ther. (2018) 21:86-90. doi: 10.1016/j.pdpdt.2017.11.005

353. Soergel P, Wang X, Stepp H, Hertel H, Hillemanns P. Photodynamic therapy of cervical intraepithelial neoplasia with hexaminolevulinate. Lasers Surg Med. (2008) 40:611-5. doi: 10.1002/1sm.20686

354. Chumworathayi B, Thinkhamrop J, Blumenthal PD, Thinkhamrop B, Pientong C, Ekalaksananan T. Cryotherapy for HPV clearance in women with biopsy-confirmed cervical low-grade squamous intraepithelial lesions. Int J Gynaecol Obstet. (2010) 108:119-22. doi: 10.1016/j.ijgo.2009. 09.012

355. De Vuyst H, Mugo NR, Franceschi S, McKenzie K, Tenet V, Njoroge J, et al. Residual disease and HPV persistence after cryotherapy for cervical intraepithelial neoplasia grade $2 / 3$ in HIV-positive women in Kenya. PLoS ONE (2014) 9:e111037. doi: 10.1371/journal.pone.0111037

356. Farhat AS, Mashayekhi V, Mahdavi R, Daghighi N. Treatment of a giant genital wart in an infant via cryotherapy: report of case. Iranian J Neonatol. (2011) 2:46-9. doi: 10.22038/IJN.2011.5155

357. Castle PE, Kreimer AR, Wacholder S, Wheeler CM, Koutsky LA, Rydzak $\mathrm{G}$, et al. Influence of loop electrosurgical excision procedure on subsequent acquisition of new human papillomavirus infections. J Infect Dis. (2009) 199:1612-20. doi: 10.1086/598981

358. Kim HS, Kwon JE, Kim JH, Kim A, Lee NR, Kim M, et al. Efficacy of loop electrosurgical excision procedure with cold coagulation for treating cervical intraepithelial neoplasia: a two center cohort study. Obstet Gynecol Sci. (2017) 60:200-6. doi: 10.5468/ogs.2017.60.2.200

359. Park IU, Introcaso C, Dunne EF. Human Papillomavirus and Genital Warts: A Review of the Evidence for the 2015 Centers for Disease Control and Prevention Sexually Transmitted Diseases Treatment Guidelines. Clin Infect Dis. (2015) 61:S849-S55. doi: 10.1093/cid/civ813

360. Davila GW, Shroyer KR. Topical 5 -fluorouracil in the treatment of cervical human papillomavirus infection. Gynecol Obstet Invest. (1996) 41:275-7. doi: $10.1159 / 000292283$

361. Niwa K, Tagami K, Lian Z, Gao J, Mori H, Tamaya T. Topical vidarabine or 5-fluorouracil treatment against persistent HPV in genital (pre)cancerous lesions. Oncol Rep. (2003) 10:1437-41. doi: 10.3892/or.10. 5.1437

362. Rahangdale L, Lippmann QK, Garcia K, Budwit D, Smith JS, van Le L. Topical 5-fluorouracil for treatment of cervical intraepithelial neoplasia 2: a randomized controlled trial. Am J Obstet Gynecol. (2014) 210:314.e1-e8. doi: 10.1016/j.ajog.2013.12.042

363. Akhtar A, Wang SX, Ghali L, Bell C, Wen X. Effective delivery of arsenic trioxide to HPV-positive cervical cancer cells using optimised liposomes: a size and charge study. Int J Mol Sci. (2018) 19:E1081. doi: 10.3390/ijms19041081 
364. Wang X, Li D, Ghali L, Xia R, Munoz LP, Garelick H, et al. Therapeutic Potential of Delivering Arsenic Trioxide into HPV-Infected Cervical Cancer Cells Using Liposomal Nanotechnology. Nanoscale Res Lett. (2016) 11:94. doi: 10.1186/s11671-016-1307-y

365. Koivusalo R, Krausz E, Ruotsalainen P, Helenius H, Hietanen S, Chemoradiation of cervical cancer cells: targeting human papillomavirus E6 and p53 leads to either augmented or attenuated apoptosis depending on the platinum carrier ligand. Cancer Res. (2002) 62:7364-71.

366. Lin CT, Qiu JT, Wang CJ, Chang SD, Tang YH, Wu PJ, et al. Topical imiquimod treatment for human papillomavirus infection in patients with and without cervical/vaginal intraepithelial neoplasia. Taiwan J Obstet Gynecol. (2012) 51:533-8. doi: 10.1016/j.tjog.2012. 09.006

367. Snoeck R, Andrei G, De Clercq E. Cidofovir in the treatment of HPVassociated lesions. Verh K Acad Geneeskd Belg. (2001) 63:93-120.

368. Mertens B, Nogueira T, Stranska R, Naesens L, Andrei G, Snoeck R. Cidofovir is active against human papillomavirus positive and negative head and neck and cervical tumor cells by causing DNA damage as one of its working mechanisms. Oncotarget (2016) 7:47302-18. doi: 10.18632/oncotarget. 10100

369. Grasso M, Remacle M, Bachy V, Van Der Vorst S, Lawson G. Use of cidofovir in HPV patients with recurrent respiratory papillomatosis. Eur Arch Otorhinolaryngol. (2014) 271:2983-90. doi: 10.1007/s00405-014-3055-x

370. Pavan MH, Velho PE, Vigani AG, Gonçalves FLJr, Aoki FH. Treatment of human papillomavirus with peg-interferon alfa-2b and ribavirin. Braz J Infect Dis. (2007) 11:383-4. doi: 10.1590/S1413-86702007000300017

371. Akbari M, Elmi R. Herpes simplex virus and human papillomavirus coinfections in hyperimmunoglobulin E syndrome presenting as a conjunctival mass lesion. Case Rep Med. (2017) 1650841. doi: $10.1155 / 2017 / 1650841$

372. Sethi N, Palefsky J. (2003). Treatment of human papillomavirus (HPV) type 16-infected cells using herpes simplex virus type 1 thymidine kinasemediated gene therapy transcriptionally regulated by the HPV E2 protein. Hum Gene Ther. 14, 45-45 doi: 10.1089/10430340360464705

373. Doudi M, Setorki M. Miraculous effect of smoke of pine tree fruit on human wart treatment: a case series. J Biol Sci. (2014) 14:381-6. doi: $10.3923 /$ jbs.2014.381.386

374. Tao P, Zheng W, Meng X, Chen J, Sun A, Shou Q, et al. Effect of paiteling on human papillomavirus infection of the cervix. Mol Clin Oncol. (2017) 7:957-64. doi: 10.3892/mco.2017.1454

375. Magnan S, Tota JE, El-Zein M, Burchell AN, Schiller JT, Ferenczy A, et al. Study Group. Efficacy of a carrageenan gel against transmission of cervical HPV (CATCH): interim analysis of a randomized, doubleblind, placebo-controlled, phase 2B trial. Clin Microbiol Infect. (2018). doi: 10.1016/j.cmi.2018.04.012. [Epub ahead of print].

376. Hellberg D, Svarrer T, Nilsson S, Valentin J. Self-treatment of female external genital warts with $0.5 \%$ podophyllotoxin cream (Condyline) vs weekly applications of $20 \%$ podophyllin solution. Int J STD AIDS (1995) 6:257-261. doi: 10.1177/095646249500600407

377. Zhang M, Yu Y, Zhang H, Huang H, Cai Q, Kang Y, et al. Synergistic cytotoxic effects of a combined treatment of a Pinellia pedatisecta lipidsoluble extract and cisplatin on human cervical carcinoma in vivo. Oncol Lett. (2017) 13:4748-54. doi: 10.3892/ol.2017.6091
378. Lea JS, Sunaga N, Sato M, Kalahasti G, Miller DS, Minna JD, et al. Silencing of HPV 18 oncoproteins With RNA interference causes growth inhibition of cervical cancer cells. Reprod Sci. (2007) 14:20-8. doi: 10.1177/1933719106298189

379. Yang J, Li S, Guo F, Zhang W, Wang Y, Pan Y. Induction of apoptosis by chitosan/HPV16 E7 siRNA complexes in cervical cancer cells. Mol Med Rep. (2013) 7:998-1002. doi: 10.3892/mmr.2012.1246

380. Franco I. Oral cimetidine for the management of genital and perigenital warts in children. J Urol. (2000) 164:1074-5. doi: 10.1016/S0022-5347(05)67254-0

381. Amer M, Tosson Z, Soliman A, Selim AG, Salem A, al-Gendy AA. Verrucae treated by levamisole. Int J Dermatol. (1991) 30, 738-740. doi: 10.1111/j.1365-4362.1991.tb02624.x

382. Nasser N. Treatment of common warts with the immune stimulant Propionium bacterium parvum. An Bras Dermatol. (2012) 87:585-9. doi: 10.1590/S0365-05962012000400011

383. Sadighha A. Oral zinc sulphate in recalcitrant multiple viral warts: a pilot study. J Eur Acad Dermatol Venereol. (2009) 23:715-6. doi: 10.1111/j.1468-3083.2009.03169.x

384. Metawea B, El-Nashar AR, Kamel I, Kassem W, Shamloul R. Application of viable bacille Calmette-Guérin topically as a potential therapeutic modality in Condylomata acuminata: a placebo-controlled study. Urology (2005) 65:247-50. doi: 10.1016/j.urology.2004.09.025

385. Recanati MA, Kramer KJ, Maggio JJ, Chao CR. Cantharidin is superior to trichloroacetic acid for the treatment of non-mucosal genital warts: a pilot randomized controlled trial. Clin Exp Obstet Gynecol. (2018) 45:383-6. doi: $10.12891 / \operatorname{ceog} 4112.2018$

386. Bhat RM, Vidya K, Kamath G. Topical formic acid puncture technique for the treatment of common warts. Int J Dermatol (2001) 40:415-9. doi: 10.1046/j.1365-4362.2001.01242.x

387. Shumer SM, O'Keefe EJ. Bleomycin in the treatment of recalcitrant warts. $J$ Am Acad Dermatol. (1983) 9:91-6. doi: 10.1016/S0190-9622(83)70112-X

388. Dobson SR, McNeil S, Dionne M, Dawar M, Ogilvie G, Krajden M, et al. Immunogenicity of 2 doses of HPV vaccine in younger adolescents vs 3 doses in young women: a randomized clinical trial. JAMA (2013) 309, 1793-1802. doi: 10.1001/jama.2013.1625

389. Hassett KJ, Meinerz NM, Semmelmann F, Cousins MC, Garcea RL, Randolph TW. Development of a highly thermostable, adjuvanted human papillomavirus vaccine. Eur J Pharm Biopharm. (2015) 94:220-8. doi: 10.1016/j.ejpb.2015.05.009

Conflict of Interest Statement: The authors declare that the research was conducted in the absence of any commercial or financial relationships that could be construed as a potential conflict of interest.

Copyright (C) 2018 Dadar, Chakraborty, Dhama, Prasad, Khandia, Hassan, Munjal, Tiwari, Karthik, Kumar, Iqbal and Chaicumpa. This is an open-access article distributed under the terms of the Creative Commons Attribution License (CC BY). The use, distribution or reproduction in other forums is permitted, provided the original author(s) and the copyright owner(s) are credited and that the original publication in this journal is cited, in accordance with accepted academic practice. No use, distribution or reproduction is permitted which does not comply with these terms. 